Portland State University

PDXScholar

1987

\title{
Synthesis and characterization of some $\mathrm{SF}_{5-}$ containing sulfonic acids
}

Robert J. Willenbring

Portland State University

Follow this and additional works at: https://pdxscholar.library.pdx.edu/open_access_etds

Part of the Inorganic Chemistry Commons

Let us know how access to this document benefits you.

\section{Recommended Citation}

Willenbring, Robert J., "Synthesis and characterization of some SF5- containing sulfonic acids" (1987). Dissertations and Theses. Paper 3734.

https://doi.org/10.15760/etd.5618

This Thesis is brought to you for free and open access. It has been accepted for inclusion in Dissertations and Theses by an authorized administrator of PDXScholar. Please contact us if we can make this document more accessible: pdxscholar@pdx.edu. 
AN ABSTRACT OF THE THESIS OF Robert J. Willenbring for the Master of Arts in Chemistry presented June 4, 1987.

Title: Synthesis and Characterization of Some $\mathrm{SF}_{5}-$ Containing Sulfonic Acids

APPROVED BY MEMBERS OF THE THESIS COMMITTEE:
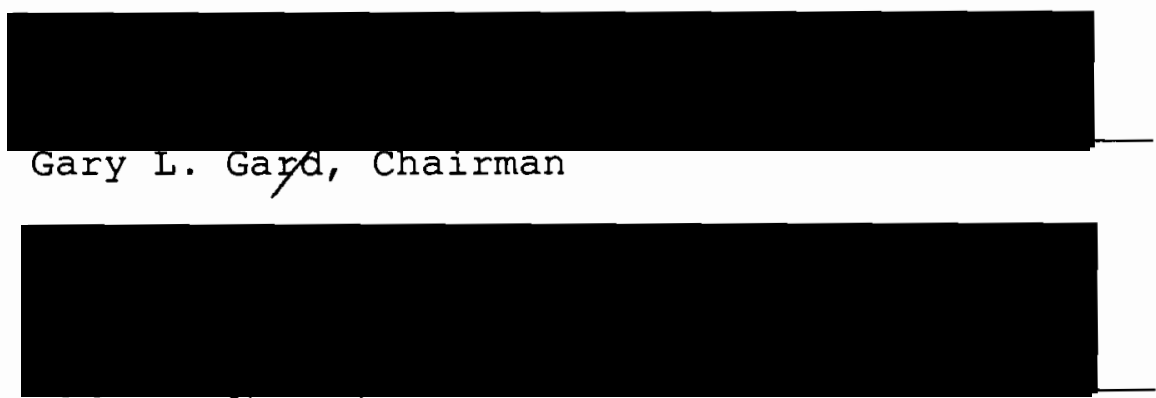

Alfred Sf: Levinson

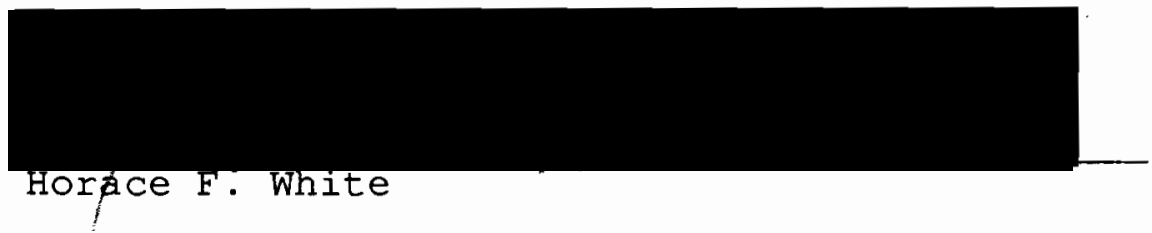

Pentafluorosulfur(VI) bromide $\left(\mathrm{SF}_{5} \mathrm{Br}\right)$ adds to olefins of the form $\mathrm{CX}_{2}=\mathrm{CX}_{2}$, where $\mathrm{X}=\mathrm{H}$ or $\mathrm{F}$, with the pentafluorosulfur group usually adding to the carbon with more hydrogens attached to it. This series of compounds was used in an attempt to prepare the corresponding sulfonic acid hydrates of the general formula $\mathrm{SF}_{5} \mathrm{CX}_{2} \mathrm{CX}_{2} \mathrm{SO}_{3} \mathrm{H} \cdot \mathrm{nH}_{2} \mathrm{O}$, in order to have these compounds tested as possible fuel cell electrolytes. The reaction scheme involved reflux of the $\mathrm{SF}_{5} \mathrm{Br}$ adduct with 
an equimolar amount of sodium sulfite in 50\% ethanol for two days, followed by acidification of the recovered solid material using $\mathrm{HCl}$ or $\mathrm{H}_{2} \mathrm{SO}_{4}$.

Upon removal of the solvent, sublimation of the solid residue gave the acids $\mathrm{SF}_{5} \mathrm{CH}_{2} \mathrm{CH}_{2} \mathrm{SO}_{3} \mathrm{H}$ and $\mathrm{SF}_{5} \mathrm{CHFCF}_{2} \mathrm{SO}_{3} \mathrm{H} \cdot \mathrm{H}_{2} \mathrm{O}$, while $\mathrm{SF}_{5} \mathrm{CH}_{2} \mathrm{CF}_{2} \mathrm{SO}_{3} \mathrm{H} \cdot \mathrm{H}_{2} \mathrm{O}$ was recovered as the major component of a binary mixture. The sodium salts corresponding to these three acids were also made by neutralization of the acids with sodium hydroxide. For the other two members of the series, $\mathrm{SF}_{5} \mathrm{CH}_{2} \mathrm{CHFSO}_{3} \mathrm{H}$ was identified as a minor component of its product mixture, while $\mathrm{SF}_{5} \mathrm{CF}_{2} \mathrm{CF}_{2} \mathrm{SO}_{3} \mathrm{H}$ was not recovered at all, possibly due to a redox reaction in which $\mathrm{SF}_{5} \mathrm{CF}_{2} \mathrm{COOH}$, sulfur, and bromine were formed. The acids could not be isolated from these last two product mixtures.

The addition of Pentafluorosulfur(VI) bromide to $\mathrm{CF}_{2}=\mathrm{CFBr}$ was used to prepare a new adduct $\mathrm{SF}_{5} \mathrm{CF}_{2} \mathrm{CFBr}_{2}$ and telomer $\mathrm{SF}_{5}\left(\mathrm{CF}_{2} \mathrm{CFBr}\right)_{10} \mathrm{Br}$. Also, addition of $\mathrm{SF}_{5} \mathrm{Br}$ to $\mathrm{CF}_{2}=\mathrm{CF}_{2}$ under mild conditions was found to produce good yields of the monomeric adduct $\mathrm{SF}_{5} \mathrm{CF}_{2} \mathrm{CF}_{2} \mathrm{Br}$, where previously the reaction had produced a telomer.

The compound $\mathrm{SF}_{5} \mathrm{CHFCF}_{2} \mathrm{SO}_{3} \mathrm{H} \cdot \mathrm{H}_{2} \mathrm{O}$ is currently undergoing preliminary testing as a fuel cell electrolyte.

Infrared, ${ }^{1} \mathrm{H}$ and ${ }^{19} \mathrm{~F}$ NMR, and mass spectra as well as elemental analyses are presented in order to support the proposed structures of these compounds. 
SYNTHESIS AND CHARACTERIZATION OF SOME

$\mathrm{SF}_{5}-$ CONTAINING SULFONIC ACIDS

by

ROBERT J. WILLENBRING

A thesis submitted in partial fulfillment of the requirements for the degree of

\section{MASTER OF ARTS}

in

CHEMISTRY

Portland State University

1987 
TO THE OEFICE OF GRADUATE STUDIES AND RESEARCH:

The members of the committee approve the thesis of Robert J. Willenbring presented June 4, 1987.
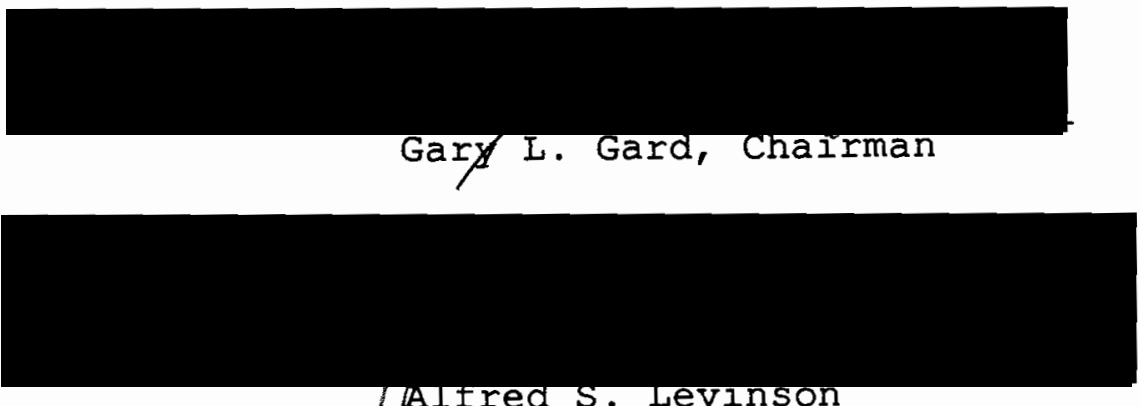

faltrea s. Levinson

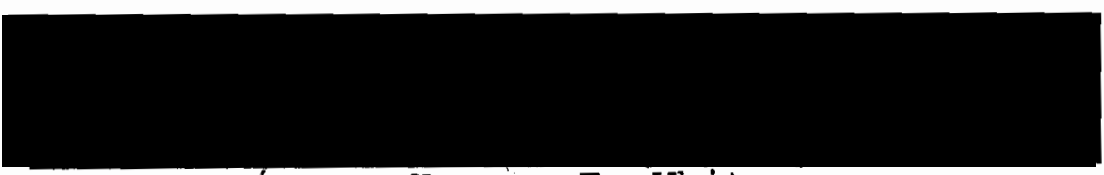

Horace $F$. White

APPROVED :

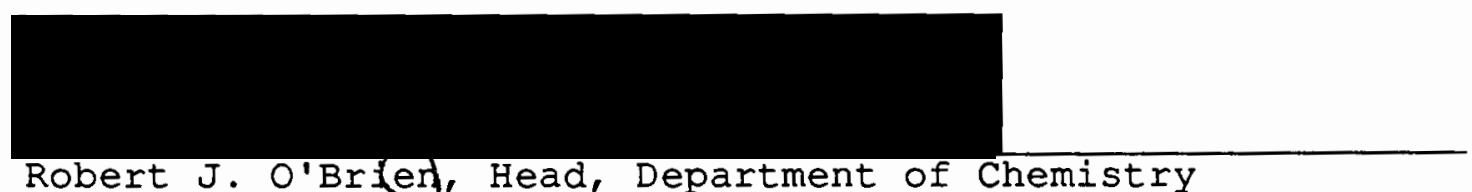

Robert J. O'Brlen, Head, Department of Chemistry

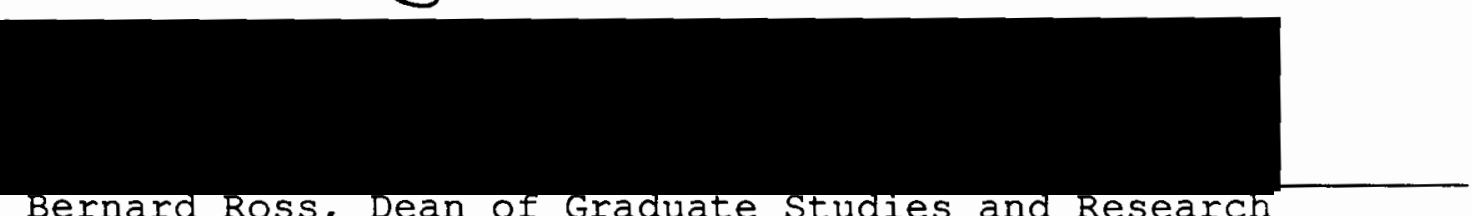

Bernard Ross, Dean of Graduate Studies and Research 


\section{ACKNOWLEDGEMENTS}

The author extends his gratitude to Dr. Gary I. Gard for all he has done to make this thesis possible. Many thanks too to the other members of the research group I have worked with: Harry Davis, Jilla Khalilolahi, Megan Lerchen, Javid Mohtasham, Roger Sheets, Robin Terjeson, and Joseph Udeaja. Their assistance and comraderie made this work both easier and enjoyable. 
TABLE OF CONTENTS

PAGE

ACKNOWLEDGEMENTS . . . . . . . . . . . . . . . . iii

IIST OF TABLES . . . . . . . . . . . . . . . . . . vi vi

LIST OF FIGURES . . . . . . . . . . . . . . . . . . . vii

CHAPTER

I INTRODUCTION . . . . . . . . . . . . . . . . . 1

Fuel Cells............... 1

Fuel Cell Electrolytes........ . 3

Sulfonic Acids as Fuel Cell Electrolytes . 6

II EXPERIMENTAL . . . . . . . . . . . . . . 9

vacuum System . . . . . . . . . . . . . . 9

Instrumentation . . . . . . . . . . 10

Reagents . . . . . . . . . . . 11

III SYNTHESIS OF $\mathrm{SF}_{5}-$ CONTAINING SULFONIC ACIDS . . 12

Discussion . . . . . . . . . . . . 12

Experimental . . . . . . . . . . . 18

Synthesis of $\mathrm{SF}_{5} \mathrm{CH}_{2} \mathrm{CH}_{2} \mathrm{SO}_{3} \mathrm{H}$

Synthesis of $\mathrm{SF}_{5} \mathrm{CH}_{2} \mathrm{CHFSO}_{3} \mathrm{H}$

Synthesis of $\mathrm{SF}_{5} \mathrm{CH}_{2} \mathrm{CF}_{2} \mathrm{SO}_{3} \mathrm{H}$

Synthesis of $\mathrm{SF}_{5} \mathrm{CHFCE}_{2} \mathrm{SO}_{3} \mathrm{H}$

At tempted synthesis of $\mathrm{SF}_{5} \mathrm{CF}_{2} \mathrm{CF}_{2} \mathrm{SO}_{3} \mathrm{H}$

using iodide adduct

At tempted synthesis of $\mathrm{SF}_{5} \mathrm{CF}_{2} \mathrm{CF}_{2} \mathrm{SO}_{3} \mathrm{H}$

using bromide adduct

Elemental Analysis . . . . . . . . 29

Infrared Spectra . . . . . . . . . . 31 
NMR Spectra • . . . . . . . . . . . 37

Mass Spectra. . . . . . . . . . . . . 43

IV OTHER REACTIONS . . . . . . . . . . . . . 50

Discussion. . . . . . . . . . . . 50

Experimental . . . . . . . . . . . 51

Synthesis of $\left(\mathrm{CF}_{3} \mathrm{SO}_{2}\right)_{2} \mathrm{CHNa}$

Attempted synthesis of $\left(\mathrm{CF}_{3} \mathrm{SO}_{2}\right)_{2} \mathrm{CHSO}_{3} \mathrm{Na}$

Reaction of $\mathrm{CF}_{3} \mathrm{CH}_{2} \mathrm{I}$ with $\mathrm{Na}_{2} \mathrm{SO}_{3}$

Reaction of $\left(\mathrm{CH}_{3} \mathrm{~S}\right)_{3} \mathrm{CH}$ with $\mathrm{Cl}_{2} / \mathrm{H}_{2} \mathrm{O}$

Reaction of $\mathrm{SF}_{5} \mathrm{Br}$ with $\mathrm{CF}_{2}=\mathrm{CFBr}$

Reaction of $\mathrm{CF}_{3} \mathrm{CH}_{2} \mathrm{I}$ with $\mathrm{Na}_{2} \mathrm{SO}_{3}$ in 508 ethanol

Elemental Analysis . . . . . . . . 53

IR Spectra . . . . . . . . . . . . 54

${ }^{19} \mathrm{~F}$ NMR Spectra . . . . . . . . . . 56

Mass Spectrum . . . . . . . . . . 57

V CONCLUSION . . . . . . . . . . . . . . . 60

REEERENCES • . . . . . . . . . . . . . . . . . . 61

APPENDIX . . . . . . . . . . . . . . . . . . . 64 


\section{LIST OF TABLES}

TABLE

PAGE

I Elemental Analysis of Sulfonic Acids . . . . 30

II IR Data for $\mathrm{SF}_{5} \mathrm{CH}_{2} \mathrm{CH}_{2} \mathrm{SO}_{3} \mathrm{H}\left(\mathrm{cm}^{-1}\right)$. . . . . . . 32

III IR Data for $\mathrm{SF}_{5} \mathrm{CH}_{2} \mathrm{CH}_{2} \mathrm{SO}_{3} \mathrm{Na}\left(\mathrm{cm}^{-1}\right)$. . . . . . 33

IV IR Data for $\mathrm{SF}_{5} \mathrm{CH}_{2} \mathrm{CF}_{2} \mathrm{SO}_{3} \mathrm{H} \cdot \mathrm{H}_{2} \mathrm{O}\left(\mathrm{cm}^{-1}\right)$. . . . 34

$\mathrm{V}$ IR Data for $\mathrm{SF}_{5} \mathrm{CH}_{2} \mathrm{CF}_{2} \mathrm{SO}_{3} \mathrm{Na}\left(\mathrm{cm}^{-1}\right)$. . . . . 35

VI IR Data for $\mathrm{SF}_{5} \mathrm{CHFCF}_{2} \mathrm{SO}_{3} \mathrm{H} \cdot \mathrm{H}_{2} \mathrm{O}\left(\mathrm{cm}^{-1}\right) . . . \cdot 36$

VII IR Data for $\mathrm{SF}_{5} \mathrm{CHFCF}_{2} \mathrm{SO}_{3} \mathrm{Na}\left(\mathrm{cm}^{-1}\right)$. . . . . . 37

VIII NMR Data for $\mathrm{SF}_{5} \mathrm{CH}_{2} \mathrm{CH}_{2} \mathrm{SO}_{3} \mathrm{H}$. . . . . . . . . 38

IX NMR Data for $\mathrm{SF}_{5} \mathrm{CH}_{2} \mathrm{CH}_{2} \mathrm{SO}_{3} \mathrm{Na}$. . . . . . . . 39

X NMR Data for $\mathrm{SF}_{5} \mathrm{CH}_{2} \mathrm{CF}_{2} \mathrm{SO}_{3} \mathrm{H} \cdot \mathrm{H}_{2} \mathrm{O}$. . . . . . . 40

XI NMR Data for $\mathrm{SF}_{5} \mathrm{CH}_{2} \mathrm{CF}_{2} \mathrm{SO}_{3} \mathrm{Na} \cdot$. . . . . . . . 41

XII NMR Data for $\mathrm{SF}_{5} \mathrm{CHFCF}_{2} \mathrm{SO}_{3} \mathrm{H} \cdot \mathrm{H}_{2} \mathrm{O}$. . . . . . . . 42

XIII NMR Data for $\mathrm{SF}_{5} \mathrm{CHFCF}_{2} \mathrm{SO}_{3} \mathrm{Na}$. . . . . . . . . 43

XIV Mass Spectrum of $\mathrm{SE}_{5} \mathrm{CH}_{2} \mathrm{CH}_{2} \mathrm{SO}_{3} \mathrm{H}$. . . . . . . . 44

$\mathrm{XV}$ Mass Spectrum of $\mathrm{SF}_{5} \mathrm{CH}_{2} \mathrm{CF}_{2} \mathrm{SO}_{3} \mathrm{H} \cdot \mathrm{H}_{2} \mathrm{O}$. . . . . $\quad 45$

XVI Mass Spectrum of $\mathrm{SF}_{5} \mathrm{CHFCF}_{2} \mathrm{SO}_{3} \mathrm{H} \cdot \mathrm{H}_{2} \mathrm{O}$. . . . . . 46

XVII Mass Spectrum of $\mathrm{SF}_{5} \mathrm{CH}_{2} \mathrm{CH}_{2} \mathrm{SO}_{3} \mathrm{Na}$. . . . . . . 47

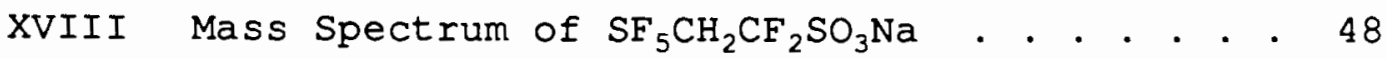

XIX Mass Spectrum of $\mathrm{SF}_{5} \mathrm{CHFCF}_{2} \mathrm{SO}_{3} \mathrm{Na}$. . . . . . . 49

$\mathrm{XX}$ Elemental Analysis for $\mathrm{SF}_{5} \mathrm{CF}_{2} \mathrm{CFBr}_{2}$ and

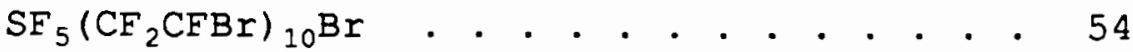

XXI IR Data for $\mathrm{SF}_{5} \mathrm{CF}_{2} \mathrm{CFBr}_{2}\left(\mathrm{~cm}^{-1}\right)$. . . . . . . 55 
$\boldsymbol{v i}$

XXII IR Data for $\mathrm{SF}_{5}\left(\mathrm{CF}_{2} \mathrm{CFBr}\right)_{10} \mathrm{Br}\left(\mathrm{cm}^{-1}\right) \cdot \cdots \cdot . \cdot 55$ XXIII NMR Data for $\mathrm{SF}_{5} \mathrm{CF}_{2} \mathrm{CFBr}_{2}$. . . . . . . . . 56 XXIV NMR Data for $\mathrm{SF}_{5}\left(\mathrm{CF}_{2} \mathrm{CFBr}\right)_{10} \mathrm{Br}$. . . . . . 57 $\mathrm{XXV}$ Mass Spectrum of $\mathrm{SF}_{5} \mathrm{CF}_{2} \mathrm{CFBr}_{2}$. . . . . . . 58 


\section{LIST OF FIGURES}

FIGURE

PAGE

1 A Typical Acid Electrolyte Fuel Cell . . . . 1

2 Synthetic Scheme for $\mathrm{SF}_{5} \mathrm{CFHCF}_{2} \mathrm{SO}_{3} \mathrm{H}$. . . . . 14

3 Reaction Scheme for conversion of $\mathrm{SF}_{5} \mathrm{CX}_{2} \mathrm{CX}_{2} \mathrm{Br}$ to $\mathrm{SF}_{5} \mathrm{CX}_{2} \mathrm{CX}_{2} \mathrm{SO}_{3} \mathrm{H} \cdot \cdot \cdot \cdot \cdot \cdot \cdot 15$

4 Free Radical Mechanism . . . . . . . . 16

5 Carbene Mechanism . . . . . . . . . 17 


\section{CHAPTER I}

\section{INTRODUCTION}

\section{FUEI CELLS}

A fuel cell is a device in which the chemical energy of a fuel is converted to electrical energy without first being converted into heat. Ideally, the cell is a static system, in that it remains invariant while oxidant and fuel are supplied and electricity and other products are removed. The fuel is oxidized, just as in a normal combustion process, but by separating the oxidation and reduction reactions the electrons can be forced to flow through a wire and do work (see Figure 1). While fuel cells are

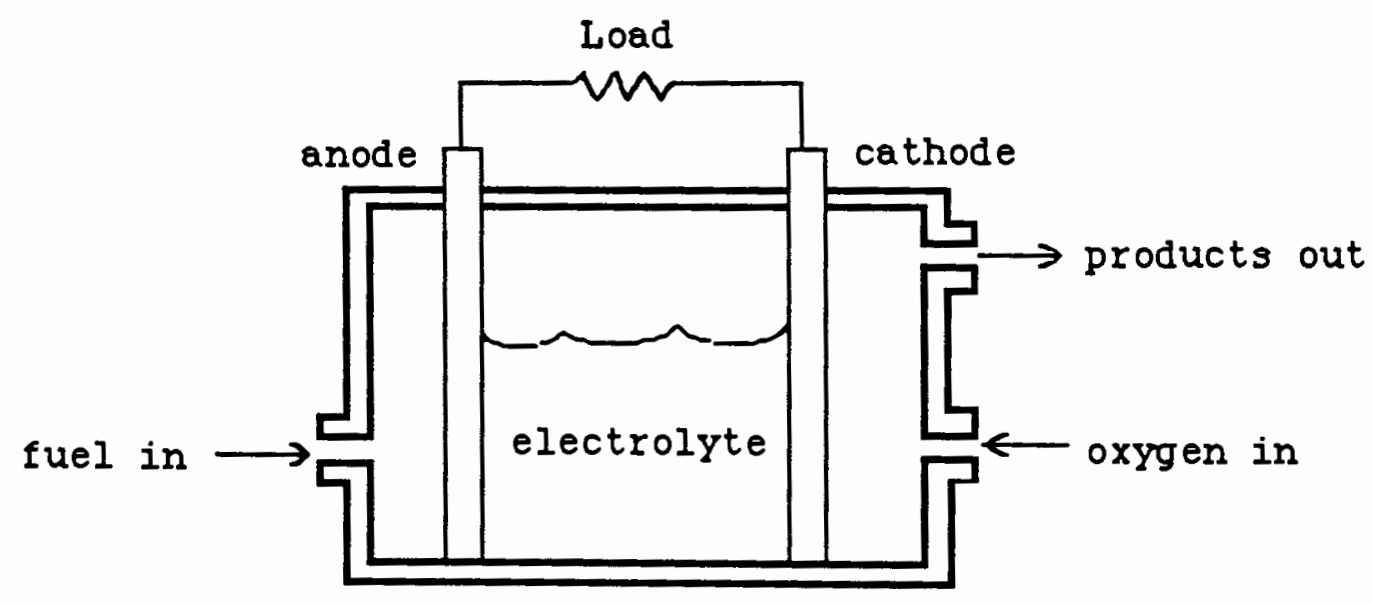

Eigure 1. A typical acid electrolyte fuel cell. 
conceptually simple, they have proved a difficult concept to realize, due to problems in maintaining an invariant structure and in enhancing the reaction kinetics in order to generate high current densities.1,2,3

In a typical acid electrolyte fuel cell, the gaseous fuel is fed through a porous electrode made of platinum bonded to Teflon. The platinum serves both as electrode and catalyst for the reaction, while the Teflon is an inert support material. Oxidation occurs at the phase boundary between the fuel gas, the electrode, and the electrolyte solution, and fuel which doesn't react before leaving the electrode either bubbles out of the solution or diffuses to the cathode and reacts directly with oxygen.

The electrons from the anode reaction travel through an external circuit to the cathode, while the hydrogen ions are transported there by the electrolyte. The cathode is another gas diffusion electrode, where again the reaction between oxygen, hydrogen ions, and electrons must take place in the three phase boundary between electrode, gas, and electrolyte. Most acid electrolyte fuel cells are operated at a high enough temperature that water, the sole product if hydrogen is used as fuel, can be removed as steam, to prevent dilution of the electrolyte.

There are several methods which can be employed in order to generate a higher current density in a fuel cell. 
Increasing the size of the electrodes (they are usually shaped like flat plates, so their size is given by their area), increases the surface available for reaction, which increases the output. While this is easy to do, the platinum electrodes are a major part of the cost of a cell, so this isn't a cost effective solution.

Most fuel cells are run at elevated temperatures, to improve their reaction kinetics. Phosphoric acid fuel cells operate at about $200^{\circ} \mathrm{C}$, while sulfonic acid cells typically operate at $120^{\circ} \mathrm{C}$ to $150^{\circ} \mathrm{C}$. The temperature is determined more by the stability of the cell materials than anything else; cells are usually run at the highest temperature they can survive.

These two solutions involve changing physical parameters, while the remaining two involve changing the components of the cell. Catalysis of the reactions will increase the reaction rate and allow for higher currents to be produced. The platinum electrode acts as a catalyst for the anode reaction, so much of the research is directed at finding a suitable catalyst for the cathode reaction, and at finding an inexpensive replacement for the platinum.

FUEL CELL ELECTROLYTES

The current density of a fuel cell may also be increased by altering the electrolyte. Concentrated 
phosphoric acid is the electrolyte used in first generation fuel cells, but its failings as an electrolyte have spurred much of the current research into improved catalysts and a replacement electrolyte. Some of the characteristics which an ideal electrolyte should possess are: ${ }^{4}$

1) High ionic conductivity and acid strength. High conductivity and acid strength reflect fast proton transport through the solution, which makes it possible to operate the cell at lower temperatures and still maintain a reasonable reaction rate.

2) Low vapor pressure. The electrolyte must remain in the cell while water and other reaction products are removed, usually by evaporation. Also, the vapor pressure of water over the electrolyte must be balanced with the rate of formation of water, so the concentration of the electrolyte remains constant. For phosphoric acid, a concentrated solution is required to accomplish this, while for sulfonic acids a dilute solution is sufficient. 5

3) Electrochemical and thermal stability. The electrolyte must not decompose or react with any of the cell materials. Aside from the loss of electrolyte, the products of such reactions may interfere with the cell operation in other ways. The electrolyte also cannot act as an electron carrier (i.e. it must not be oxidized or reduced under cell conditions) in addition to an ion carrier, as this will allow the electrons to circumvent the external circuit. 
4) Chemical inertness. It must not react with the materials of the cell. of particular importance are adsorption on or reaction with the platinum electrodes by either the electrolyte or its anion. ${ }^{6}$ while phosphoric acid doesn't affect the operation of the electrode, under cell operating conditions it can be reduced to other phosphorus oxides which do.?

5) Favorable surface activity. The electrolyte should not wet Teflon, which is used as a binder and seal in the electrodes, and it should not foam excessively when gases are bubbled through it. If the Teflon becomes wetted, capillary action floods the electrode with electrolyte and the gas flow becomes blocked. ${ }^{8}$

6) High oxygen and hydrogen solubility. The gases must react while they are still in contact with the electrodes, so if the gases can go into solution this increases the effective surface area of the electrode.

In addition, an electrolyte which will support use of hydrocarbon fuels is desirable. Phosphoric acid is suitable for purified reformate fuels, where the steam from the cell operation is used in the reforming process, and the carbon monoxide is removed by a shift reaction, 9 but the fuel processing is then a major energy drain on the cell output.

Both perfluoroalkane carboxylic acids and perfluoroalkane sulfonic acids meet the requirements for acidity, solubility, and stability needed to be effective as an 
electrolyte. The organic end of the molecule in both cases allows for flexibility in tailoring the molecule to fit the needed characteristics, but in general, the perfluoroalkane carboxylic acids are too volatile for use in a fuel cell. The first system studied as a potential replacement for phosphoric acid was trifluoromethanesulfonic acid (TFMSA). The success of this acid demonstrated that the search for a better electrolyte was a viable alternative to the search for improved electrocatalysts in improving fuel cell performance. 10

In looking at sulfonic acids as possible fuel cell electrolytes, the length of the organic tail is significant. Shorter chain length sulfonic acids have relatively high vapor pressures, but increasing the chain length to more than four makes them extremely surface active.11 This creates problems both with wetting of the Teflon electrode binding and with foaming in the cell as the gases bubble out. Introduction of functional groups that decrease the vapor pressure without affecting the surface activity is one possible solution, and this is the route looked at in this thesis.

\section{SULFONIC ACIDS AS FUEL CELL ELECTROLYTES}

In a direct comparison with phosphoric acid using synthetic reformate fuel mixtures, trifluoromethanesulfonic 
acid showed four times the performance level overall as measured by current density under different operating conditions. ${ }^{12}$ one of the main factors limiting the efficiency of phosphoric acid is the overpotential for oxygen reduction on platinum. This causes oxygen reduction to be two orders of magnitude slower for phosphoric acid than for aqueous TFMSA. ${ }^{13}$

The cathode reaction in a fuel cell is first order in both oxygen concentration and proton activity. ${ }^{14}$ TFMSA is one of the strongest protic acids known, as it will protonate sulfuric acid, 15 and it is a much stronger acid than phosphoric acid. Also, the concentrated phosphoric acid solutions that must be used in fuel cells have low oxygen solubility. TFMSA shows higher oxygen solubility, due mainly to the ability to use dilute solutions and still maintain high ionic conductivity while preventing wetting of Tefion.

The high conductivity of the TFMSA fuel cell allows it to operate effectively at the lower temperatures where TFMSA is stable, around $60^{\circ} \mathrm{C}$. Though higher temperatures will cause decomposition of TFMSA, these cells are usually run at about $120^{\circ} \mathrm{C}$, in order to prevent poisoning of the platinum electrode by carbon monoxide, one of the components of reformate fuels. ${ }^{16}$

The success of TFMSA has spurred interest in other sulfonic acids as potential fuel cell electrolytes. Most of 
the research is centered on short chain sulfonic acids, and usually methane or ethane derivatives. Methanesulfonic acid, methanedi- and tri-sulfonic acids and their perchloroanalogues, 17 ethanedisulfonic acid and tetrafluoroethanedisulfonic acid ${ }^{18}$ among others have been made and tested as potential fuel cell electrolytes. While none of them have been entirely successful, they show enough promise to indicate that these or similar compounds will eventually replace phosphoric acid as the leading acid fuel cell electrolyte.

This chapter has provided a general overview of fuel cells and their electrolytes. In the next chapter, the equipment, reagents, and methods used in the synthesis and characterization of several sulfonic acids will be described. Chapters III and IV contain the experimental results, and Chapter $\mathrm{V}$ contains a summary of the results and suggestions for further work. 
CHAPTER 2

EXPERIMENTAL

VACUUM SYSTEM

Gases and volatile liquids were manipulated in a single manifold vacuum line constructed of $25 \mathrm{~mm}$ inside diameter Pyrex glass tubing to which four Eck and Krebs $2 \mathrm{~mm}$ high vacuum stopcocks with Pyrex Standard Taper 10/30 ground glass outer joints were attached. Pressure was measured using a Frederick Televac vacuum guage and thermocouple or a mercury manometer. The line was evacuated through a liquid $\mathrm{N}_{2}$ trap by a Welch Duo-Seal vacuum pump. A Consolidated Vacuum Corporation two-stage oil diffusion pump was also attached, though it was only used to calibrate the vacuum guage. With the rotary and diffusion pumps both operating, the Televac was set to read $0.0 \mu$. Normal operating pressures were less than $5 \mu$ unless otherwise noted. All joints and stopcocks were lubricated with either Apiezon M or Fluorolube GR-290 grease. Vacuum guage connections were sealed with Halocarbon wax.

High pressure reactions were carried out in a stainless steel Hoke vessel equipped with a Whitey stainless steel valve and a brass Standard Taper $10 / 30$ inner joint. Metal vessels with volumes of $75 \mathrm{~mL}, 150 \mathrm{~mL}$, and $300 \mathrm{~mL}$ were used. 
Low pressure gas reactions were carried out in a 1, 2, or 3 liter Pyrex glass vessel equipped with a cold finger for condensing materials into them, and a Kontes stopcock with a Standard Taper 10/30 inner joint. Other reactions were carried out in Pyrex Standard Taper glassware using Fluorolube GR-290 grease to seal the joints.

\section{INSTRUMENTATION}

NMR spectra were obtained on a Varian EM-390 Spectrometer operating at $90.00 \mathrm{MHz}$ for ${ }^{1} \mathrm{H}$ and $84.67 \mathrm{MHz}$ for ${ }^{19} \mathrm{~F}$. TMS and Freon-11 external standards were used. A Nicolet 20 DX FTIR spectrometer operating at $2.0 \mathrm{~cm}^{-1}$ resolution was used to obtain the IR spectra. Gas IR spectra were taken using an $8.5 \mathrm{~cm}$ path length cell with $\mathrm{KBr}$ or KRS-5 windows. Solid and liquid IR spectra were taken on $\mathrm{KBr}$ or KRS-5 disks. Mass spectra were measured on a VG 7070 HS mass spectrometer operated at $70 \mathrm{eV}$. Perfluorokerosene was used as an internal standard. $\mathrm{SF}_{5} \mathrm{CF}_{2} \mathrm{CFBr}_{2}$ was purified using an Aerograph Autoprep A-700 gas chromatograph equipped with a 10' $x$ 3/8" column packed with $20 \%$ Carbowax adsorbed on Chromosorb $\mathrm{w}$. Melting points were determined on a MelTemp melting point apparatus. Melting and boiling points were uncorrected. 


\section{REAGENTS}

All reactants were reagent grade and were used as purchased unless noted otherwise. Chemicals were obtained from Aldrich Chem. Co. (benzoyl peroxide, sodium sulfite $\left(98+\frac{9}{8}\right)$, sodium bisulfite, tris-thiomethylmethane (99\%), and 1,1,1-trifluoro-2-iodoethane (99\%)), J.T. Baker Chem. Co. (bromine, sulfuric acid (95.6\%), sodium hydroxide, and sodium borate), Mallinckrodt Chem. Works (iodine), Matheson (hydrogen chloride, tech. grade), Peninsular Chem. Research (vinyl fluoride, 1,1-difluoroethene, trifluoroethene, tetrafluoroethene, and bromotrifluoroethene) and Air Products and Chemicals (ethylene). Water was deionized using a Crystalab CL-5 water demineralizer. $\mathrm{SF}_{5} \mathrm{Br}$ was prepared and handled by literature methods. 19 
CHAPTER III

\section{SYNTHESIS OF $\mathrm{SF}_{5}-$ CONTAINING SULFONIC ACIDS DISCUSSION}

In the introduction it was stated that in order for an alkanesulfonic acid to be effective as a fuel cell electrolyte, it should have a short chain length to prevent wetting of Teflon, and it should have a low vapor pressure. It should also not contain a terminal $\mathrm{CH}_{3}-$ group and possibly not contain any $\mathrm{C}-\mathrm{H}$ bonds, as adsorption on platinum may block the catalyst. 20 while increasing the chain length would decrease the vapor pressure, the problem with surface activity made other methods, such as the use of hydrates instead of anhydrous acids and the introduction of bulky functional groups, better for achieving a lower vapor pressure.

Compounds of the general form $\mathrm{SF}_{5} \mathrm{CX}_{2} \mathrm{CX}_{2} \mathrm{Br}$ where $\mathrm{X}=\mathrm{H}$ or F were chosen as starting materials, as they would generate sulfonic acids of the form $\mathrm{SF}_{5} \mathrm{CX}_{2} \mathrm{CX}_{2} \mathrm{SO}_{3} \mathrm{H}$, which should meet the criteria outlined above. All but the perfluorinated adduct $\mathrm{SF}_{5} \mathrm{CF}_{2} \mathrm{CF}_{2} \mathrm{Br}$ had been reported, and they could easily be synthesized by the addition of $\mathrm{SF}_{5} \mathrm{Br}$ to the appropriate olefin.21 The tetrafluoroethylene adduct had been isolated in small amounts as a by-product in the synthesis of the 
corresponding telomer, 22 and as it was thought that telomer formation would predominate in this reaction, $\mathrm{SF}_{5} \mathrm{CF}_{2} \mathrm{CF}_{2} \mathrm{I}$ was prepared by a different method ${ }^{23}$ for use as a starting material. It was later found that by running the reaction under suitably mild conditions, the bromide monomer was produced in good yields. Since synthesis of the iodide was a messy multistep process, it was hastily abandoned in favor of the $\mathrm{SF}_{5} \mathrm{Br}$ adduct.

Three general schemes have been used in the synthesis of fluorinated sulfonic acids from the corresponding halide. ${ }^{24}$ The oldest is the strecker reaction, in which an alkyl halide is reacted with hot aqueous alkali metal sulfite, giving a sulfonic acid salt. Acidification of the salt gives the sulfonic acid. This reaction is considered unreliable, inefficient, and complicated, 25.26 because of the inability to isolate the sulfonate salt, which is formed with other salts having similar solubility characteristics. The second method involves metal bisulfite addition to fluoroolefins, which can be made by dehydrohalogenation of the bromide or iodide. The salt is then treated with $100 \%$ $\mathrm{H}_{2} \mathrm{SO}_{4}$ and the sulfonic acid is distilled out of the mixture. This method was used to prepare $\mathrm{SF}_{5} \mathrm{CFHCF}_{2} \mathrm{SO}_{3} \mathrm{M}$ where $\mathrm{M}=\mathrm{H}$ or $\mathrm{Na}^{27}$ (see Figure 2). 


$$
\begin{gathered}
\mathrm{SF}_{5} \mathrm{CFHCF}_{2} \mathrm{Br}+\mathrm{KOH}==\Rightarrow \mathrm{SF}_{5} \mathrm{CF}=\mathrm{CF}_{2}+\mathrm{KBr}+\mathrm{H}_{2} \mathrm{O} \\
\mathrm{SF}_{5} \mathrm{CF}=\mathrm{CF}_{2}+\mathrm{NaHSO}_{3}==\Rightarrow \mathrm{SF}_{5} \mathrm{CFHCF}_{2} \mathrm{SO}_{3} \mathrm{Na} \\
\mathrm{SF}_{5} \mathrm{CFHCF}_{2} \mathrm{SO}_{3} \mathrm{Na}+\mathrm{H}_{2} \mathrm{SO}_{4}==\Rightarrow \mathrm{SF}_{5} \mathrm{CFHCF}_{2} \mathrm{SO}_{3} \mathrm{H}+\mathrm{NaHSO}_{4}
\end{gathered}
$$

Eigure 2. Synthetic scheme for $\mathrm{SF}_{5} \mathrm{CFHCF}_{2} \mathrm{SO}_{3} \mathrm{H}$.

The yield for this scheme was $6.7 \%$ based on the olefin. While dehydrohalogenation of the other adducts should give olefins which could then be converted into the acids using this method, the yield for this process was rather low, and perfluoroalkanesulfonic acids cannot be made by this route.

Finally, conversion of the alkyl halide into a thioether followed by oxidation generated the sulfonic acid directly. Benzyl mercaptan and an appropriate alkyl chloride were used as starting materials, 28 but the odor associated with the mercaptan was sufficient cause to abandon this scheme.

The reaction of the alkyl halide with $\mathrm{Na}_{2} \mathrm{SO}_{3}$ in $50 \%$ ethanol was found to give a good yield of the sulfonate salt for all but the perfluorinated adduct. Here the salt still seemed to be formed, but in much lower yields. The salts were extracted from the reaction mixture using hot $100 \%$ ethanol. It was soon learned that due to the solubility of the other reaction products in this solvent, a clean separation was not being achieved, so the extractions were abandoned. 
Instead, the sulfonic acids were formed by treating the entire recovered solid with acid. Treating the crude salts with $100 \% \mathrm{H}_{2} \mathrm{SO}_{4}$ generated large amounts of colorless gas along with some bromine, and usually resulted in significant amounts of charring as the mixture was distilled to isolate the anhydrous acid.

Acidification using $\mathrm{HCl} / \mathrm{H}_{2} \mathrm{O}^{29}$ was adopted to avoid these problems, as this method served both to turn the salt into the acid and to isolate it from the other salts in the mixture (see Figure 3 ). In this method the sulfonic acid remains in solution, while the other salts precipitate and

$$
\begin{gathered}
\mathrm{SF}_{5} \mathrm{CX}_{2} \mathrm{CX}_{2} \mathrm{Br}+\mathrm{Na}_{2} \mathrm{SO}_{3}=\Rightarrow \mathrm{SF}_{5} \mathrm{CX}_{2} \mathrm{CX}_{2} \mathrm{SO}_{3} \mathrm{Na}+\mathrm{NaBr} \\
\mathrm{SF}_{5} \mathrm{CX}_{2} \mathrm{CX}_{2} \mathrm{SO}_{3} \mathrm{Na}+\mathrm{HCl}(\mathrm{aq})==\Rightarrow \mathrm{SF}_{5} \mathrm{CX}_{2} \mathrm{CX}_{2} \mathrm{SO}_{3} \mathrm{H}+\mathrm{NaCl}(\mathrm{s}) \\
\text { Eigure 3. Reaction scheme for conversion of } \\
\mathrm{SF}_{5} \mathrm{CX}_{2} \mathrm{CX}_{2} \mathrm{Br} \text { to } \mathrm{SF}_{5} \mathrm{CX}_{2} \mathrm{CX}_{2} \mathrm{SO}_{3} \mathrm{H} .
\end{gathered}
$$

were removed by filtration. Evaporation of the saturated $\mathrm{HCl}$ followed by repeated sublimation of the solid material resulted in the pure acid hydrates of $\mathrm{SF}_{5} \mathrm{CH}_{2} \mathrm{CH}_{2} \mathrm{SO}_{3} \mathrm{H}$ and $\mathrm{SF}_{5} \mathrm{CHFCF}_{2} \mathrm{SO}_{3} \mathrm{H}$ in good yields.

For the other members of the series, mixed products resulted. With $\mathrm{SF}_{5} \mathrm{CH}_{2} \mathrm{CF}_{2} \mathrm{SO}_{3} \mathrm{H}$, repeated sublimation gave a product that was about $80 \%$ sulfonic acid and $20 \%$ some other compound, based on the integration of the $\mathrm{SF}_{5}$ - peaks in the ${ }^{19} \mathrm{~F}$ NMR spectrum. The impurity exhibited an additional fluorine resonance at $-105.5 \mathrm{ppm}\left(\mathrm{J}_{\mathrm{HF}}=27.1 \mathrm{~Hz}\right.$ (doublet), 
$\mathrm{J}_{\mathrm{F}-\mathrm{SF} 4}=21.2 \mathrm{~Hz}$ (pentet), $\mathrm{J}_{\mathrm{F}-\mathrm{SF}}=3.7 \mathrm{~Hz}$ (doublet)), and a ${ }^{1} \mathrm{H}$ resonance at $7.15 \mathrm{ppm}\left(\mathrm{J}_{\mathrm{H}-\mathrm{SF} 4}=7.9 \mathrm{~Hz}\right.$ (pentet), $\mathrm{J}_{\mathrm{HF}}=27.1 \mathrm{~Hz}$ (doublet)). The $\mathrm{SF}_{5}$ - pattern was a doublet at $69.0 \mathrm{ppm}$ and a nine-line pattern at $77.5 \mathrm{ppm}$, with $\mathrm{J}_{\mathrm{SF}-\mathrm{SF} 4}=147 \mathrm{~Hz}$. The NMR data were consistent with a partial structure of $\mathrm{SF}_{5}-\mathrm{CHX}$ $C F Y Z$, where $X, Y$, and $Z$ were neither $H$ nor $F$.

While this reaction is generally thought to proceed through a nucleophilic substitution mechanism, with the lone pair on the sulfur displacing the $\mathrm{C}-\mathrm{Br}$ bond, 30 a free radical mechanism has been postulated for similar reactions ${ }^{31}$ (see Figure 4). Investigation of the effect of free radical

$$
\begin{gathered}
\mathrm{SF}_{5} \mathrm{CX}_{2} \mathrm{CX}_{2} \mathrm{Br}+\mathrm{SO}_{3}==\Rightarrow \mathrm{SF}_{5} \mathrm{CX}_{2} \mathrm{CX}_{2} \mathrm{Br}^{-\cdot}+\mathrm{SO}_{3}^{-} \\
\mathrm{SF}_{5} \mathrm{CX}_{2} \mathrm{CX}_{2} \mathrm{Br}^{-\cdot}==\Rightarrow \mathrm{SF}_{5} \mathrm{CX}_{2} \mathrm{CX}_{2} \cdot+\mathrm{Br}^{-} \\
\mathrm{SF}_{5} \mathrm{CX}_{2} \mathrm{CX}_{2}^{\cdot+}+\mathrm{SO}_{3}^{-}==\Rightarrow \mathrm{SF}_{5} \mathrm{CX}_{2} \mathrm{CX}_{2} \mathrm{SO}_{3}^{-\cdot} \\
\mathrm{SF}_{5} \mathrm{CX}_{2} \mathrm{CX}_{2} \mathrm{SO}_{3}^{-+}+\mathrm{SF}_{5} \mathrm{CX}_{2} \mathrm{CX}_{2} \mathrm{Br}==\Rightarrow \mathrm{SF}_{5} \mathrm{CX}_{2} \mathrm{CX}_{2} \mathrm{SO}_{3}^{-}+\mathrm{SF}_{5} \mathrm{CX}_{2} \mathrm{CX}_{2}+\mathrm{Br}^{-}
\end{gathered}
$$

\section{Eigure 4. Free radical mechanism.}

inhibitors should help to distinguish between these mechanisms.

The mixed products and the lability of the fluorines alpha to the acid group can be explained by a carbene mechanism, 32 shown for the difluoroethane adduct in Figure 5. The product of step 3, which has lost a fluorine from the alpha carbon, can go on to form the other products seen in 
this reaction. The $\mathrm{F}^{-}$generated in step 2 explains the etching of the glassware used in these reactions, and the

$$
\begin{gathered}
\mathrm{Nu}:+\mathrm{SF}_{5} \mathrm{CH}_{2} \mathrm{CF}_{2} \mathrm{Br}=\Rightarrow \mathrm{NuBr}+\mathrm{SF}_{5} \mathrm{CH}_{2} \mathrm{CF}_{2}^{-} \\
\mathrm{SF}_{5} \mathrm{CH}_{2} \mathrm{CF}_{2}^{-}==\Rightarrow \mathrm{SF}_{5} \mathrm{CH}_{2} \mathrm{CF}:+\mathrm{F}^{-} \\
\mathrm{SF}_{5} \mathrm{CH}_{2} \mathrm{CF}:+\mathrm{NaSO}_{3}^{-}==\Rightarrow \mathrm{SF}_{5} \mathrm{CH}_{2} \mathrm{C}^{-} \mathrm{FSO}_{3} \mathrm{Na}
\end{gathered}
$$

Eigure 5. Carbene mechanism.

metal corrosion noted when these reactions have been run in pressure vessels. ${ }^{33}$

With $\mathrm{SF}_{5} \mathrm{CH}_{2} \mathrm{CHFSO}_{3} \mathrm{H}$, the situation is less clear. The elemental analysis for the product generated indicates either substantial impurities are present or a different product is formed. While ${ }^{19} \mathrm{~F}$ and ${ }^{1} \mathrm{H}$ NMR contain resonances which are consistent with the sulfonic acid structure, many other peaks are present, and further study is needed before definitive statements can be made.

The synthesis of the perfluorinated sulfonic acid $\mathrm{SF}_{5} \mathrm{CF}_{2} \mathrm{CF}_{2} \mathrm{SO}_{3} \mathrm{H}$ was attempted through both the iodide and the bromide. These systems showed several differences from the other adducts. First, the yield of the salt was much lower; assuming that the solid residue from the reaction of $\mathrm{SF}_{5} \mathrm{CF}_{2} \mathrm{CF}_{2} \mathrm{Br}$ and $\mathrm{Na}_{2} \mathrm{SO}_{3}$ was entirely $\mathrm{Na}_{2} \mathrm{SO}_{3}, \mathrm{NaBr}$, and $\mathrm{SF}_{5} \mathrm{CF}_{2} \mathrm{CF}_{2} \mathrm{SO}_{3} \mathrm{Na}$, the yield for these reactions ranged from 1015\%, while the other adducts gave calculated yields of 4585\%. Second, when the salt mixture was acidified, the solid 
precipitate for this reaction was yellow. All of the other reactions gave a colorless precipitate. Finally, concentration of the acidified mixture resulted in a black, viscous liquid instead of the white solid isolated in the other reactions. Attempts to isolate a product from this liquid by distillation proved fruitless, while vacuum sublimation gave a small quantity of a yellow, waterinsoluble solid. It is possible that a redox reaction occurred, in which the carboxylic acid $\mathrm{SF}_{5} \mathrm{CF}_{2} \mathrm{COOH}$, either $\mathrm{Br}_{2}$ or $I_{2}$, and sulfur were formed. ${ }^{34}$ This would account for the difficulty in isolating a product, and explain the yellow color of the precipitate and the solid material that sublimed out of the mixture.

The remainder of this chapter contains a summary of the procedure for the reactions discussed above, as well as tabulations and more extensive discussions of the elemental analyses, ${ }^{19} \mathrm{~F}$ and ${ }^{1} \mathrm{H}$ NMR spectra, IR spectra, and mass spectroscopy .

\section{EXPERIMENTAL}

\section{Synthesis of $\mathrm{SF}_{5} \mathrm{CH}_{2} \mathrm{CH}_{2} \mathrm{SQ}_{3} \mathrm{H}$}

Beaction using sodium sulfite with a borax buffer. A $150 \mathrm{~mL}$ metal vessel to which $3.8 \mathrm{~g}$ of $\mathrm{SF}_{5} \mathrm{CH}_{2} \mathrm{CH}_{2} \mathrm{Br}$ (16 mmol), $1.8 \mathrm{~g}(0.5 \mathrm{mmol})$ of $\mathrm{Na}_{2} \mathrm{~B}_{4} \mathrm{O}_{7} \cdot 10 \mathrm{H}_{2} \mathrm{O}$, and $2.90 \mathrm{~g}(23.0 \mathrm{mmol})$ of $\mathrm{Na}_{2} \mathrm{SO}_{3}$ were added was closed and shaken. After $10.9 \mathrm{~g}$ of $\mathrm{H}_{2} \mathrm{O}$ was added the vessel was sealed, cooled to $-196^{\circ} \mathrm{C}$, and 
volatile materials were removed under vacuum. The vessel was placed in an oil bath at $105-110^{\circ} \mathrm{C}$ for 3 hours, with shaking every 15 minutes. The contents of the vessel were transferred to a beaker and the water was removed by heating. The solid residue was extracted with 40 to $60 \mathrm{~mL}$ ethanol several times. The ethanol was removed, and an IR spectrum of the solid material was taken. The spectrum showed the $\mathrm{SF}_{5}$ - group was no longer present, so the procedure was discontinued.

Beaction using sodiumbisulfite. A $75 \mathrm{~mL}$ metal vessel to which $4.8 \mathrm{~g}(20 \mathrm{mmol})$ of $\mathrm{SF}_{5} \mathrm{CH}_{2} \mathrm{CH}_{2} \mathrm{Br}, 2.3 \mathrm{~g}$ of $\mathrm{NaHSO}_{3}$, and $10.2 \mathrm{~g}$ of water were added was closed and shaken. The vessel was cooled to $-196^{\circ} \mathrm{C}$, and volatile materials were removed under vacuum. The vessel was placed in an oil bath at $120^{\circ} \mathrm{C}$ for a total of 11 hours, with shaking every 15 minutes. When the material was removed from the reaction vessel, only unreacted $\mathrm{SF}_{5} \mathrm{CH}_{2} \mathrm{CH}_{2} \mathrm{Br}(4.6 \mathrm{~g})$ was recovered.

Reaction using sodium sulfite in $50 \%$ ethanol. A $250 \mathrm{~mL}$ round bottomed flask to which $9.65 \mathrm{~g}(41.1 \mathrm{mmol})$ of $\mathrm{SF}_{5} \mathrm{CH}_{2} \mathrm{CH}_{2} \mathrm{Br}, 5.29 \mathrm{~g}$ (42.0 mmol) of $\mathrm{Na}_{2} \mathrm{SO}_{3}$, and $140 \mathrm{~mL} 50 \%$ ethanol were added, was attached to a Fredrick condenser. The mixture was refluxed with stirring for $50 \mathrm{hr}$. The solvent was removed, the residue was extracted twice with 50 to $60 \mathrm{~mL}$ ethanol, and the extracts were dried on a vacuum line. The yield was $5.62 \mathrm{~g}(21.8 \mathrm{mmol})$ crude sulfonate salt, m.p. $270^{\circ} \mathrm{C}$ (dec) . 
Acid distillation using $100 \% \mathrm{H}_{2} \mathrm{SO}_{4}$. A $25 \mathrm{~mL}$ round bottom flask to which $0.5 \mathrm{~g}$ of $100 \% \mathrm{H}_{2} \mathrm{SO}_{4}$ (an additional 1.70 $g$ were added later) and $4.0 \mathrm{~g}(15 \mathrm{mmol})$ of the crude salt were added was attached to a semimicrodistillation apparatus. After degassing, the mixture was distilled under vacuum. A few drops of product were collected in two fractions, one at $120^{\circ} \mathrm{C}$ and the other at $140^{\circ} \mathrm{C}(150-200 \mu)$. Significant charring occurred to the products upon standing, so they were discarded.

Acidification using $\mathrm{H}_{2} \mathrm{SO}_{4}$. A $50 \mathrm{~mL}$ round bottom flask containing $4.8 \mathrm{~g}(19 \mathrm{mmol})$ of crude salt, $12.1 \mathrm{~g}$ water and $0.94 \mathrm{~g}$ of $30 \% \mathrm{H}_{2} \mathrm{SO}_{4}$ was heated with stirring until the temperature reached $55^{\circ} \mathrm{C}$, after which it was allowed to $c 001$. The solvent was removed, and the solid material was extracted with $\mathrm{CF}_{2} \mathrm{ClCFCl}_{2}$ and ether. The IR spectrum showed no $\mathrm{SF}_{5}$ - group in the extract or the residue.

\section{Acidification using HCl. A $200 \mathrm{~mL} 3$-neck flask} containing $19.1 \mathrm{~g}$ of crude salt (estimated $10.1 \mathrm{~g}$ of the sulfonic acid salt, $9.0 \mathrm{~g}$ of other salts) dissolved in about $100 \mathrm{~mL} \mathrm{H} \mathrm{H}_{2} \mathrm{O}$ was equipped with a reflux condenser, $\mathrm{HCl}$ gas bubbler, and a Teflon stirring bar. HCl was bubbled in until the solution was yellow and a white precipitate had formed. The mixture was filtered using a gooch crucible, and the volume of the liquid was reduced by heating on a hot plate. The solution was transferred to a $50 \mathrm{~mL}$ roundbottom flask, and the remaining solvent was removed under vacuum. 
The solid material was sublimed under vacuum $\left(100^{\circ} \mathrm{C}\right.$ at $<10$ $\mu)$, yielding $4.3 \mathrm{~g}(18 \mathrm{mmol})$ of the sulfonic acid as a colorless crystalline solid.

Acid neutralization with $\mathrm{NaOH}$. A NaOH solution was prepared and standardized using KHP. The normality was found to be $0.0999 \mathrm{~N}$. Two solutions of $\mathrm{SF}_{5} \mathrm{CH}_{2} \mathrm{CH}_{2} \mathrm{SO}_{3} \mathrm{H}$ in water were prepared and titrated using the $\mathrm{NaOH}$ solution. The equivalent weight was found to be $231 \mathrm{~g} / \mathrm{eq}$. (calculated 236 g/eq. for the anhydrous acid). Activated charcoal was added to the solutions, and they were filtered while hot. Removal of the water, first by heating on a hot plate, then by drying under vacuum, gave the sodium salt $\mathrm{SF}_{5} \mathrm{CH}_{2} \mathrm{CH}_{2} \mathrm{SO}_{3} \mathrm{Na}, \mathrm{m} \cdot \mathrm{p}$. $268-270^{\circ} \mathrm{C}(\mathrm{dec})$.

Synthesis of $\mathrm{SF}_{5} \mathrm{CH}_{2} \mathrm{CHESO}_{3} \mathrm{H}$

Reaction using sodium sulfite in 50\% ethanol. A $250 \mathrm{~mL}$ roundbottom flask containing $15.89 \mathrm{~g}(62.81 \mathrm{mmol})$ of $\mathrm{SF}_{5} \mathrm{CH}_{2} \mathrm{CHFBr}, 120 \mathrm{~mL}$ of $50 \%$ ethanol and $8.23 \mathrm{~g}(65.3 \mathrm{mmol})$ of $\mathrm{Na}_{2} \mathrm{SO}_{3}$ was equipped with a reflux condenser and a Teflon stir bar. The mixture was refluxed while being stirred for 69 hours. The solvent was removed by heating on a hot plate, then final drying was done under vacuum. A colorless solid $(13.57 \mathrm{~g})$ was recovered, and the weight gain indicated that the salt was formed. No attempt was made to isolate the salt. 
Acidification using HCl The crude salt was placed in a $200 \mathrm{~mL} \mathrm{3-neck} \mathrm{flask} \mathrm{and} 80 \mathrm{ml}$ of water was added. The solution was stirred until the solid had dissolved, then a reflux condenser was attached and $\mathrm{HCl}$ was bubbled into the solution. Too much water was added in an attempt to dissolve some material that proved to be insoluble, so the volume of the solution was reduced to $60 \mathrm{~mL}$, the solid material was filtered off, and the acidification was restarted. After formation of a precipitate occurred, the mixture was filtered. The solvent was removed, and the solid residue was sublimed. The yield was $1.31 \mathrm{~g}(5.16$ mmol, 8.28 yield, from the bromide) damp colorless crystals, but the NMR spectrum indicated a mixture of products was present.

\section{Synthesis of $\mathrm{SE}_{5} \mathrm{CH}_{2} \mathrm{CF}_{2} \mathrm{SO}_{3} \mathrm{H}$}

Reaction using sodium sulfite in 50\% ethanol. A $100 \mathrm{~mL}$ roundbottom flask to which $3.81 \mathrm{~g}$ (14.1 mmol) of $\mathrm{SF}_{5} \mathrm{CH}_{2} \mathrm{CF}_{2} \mathrm{Br}$, $1.92 \mathrm{~g}(15.2 \mathrm{mmol})$ of $\mathrm{Na}_{2} \mathrm{SO}_{3}$, and $50 \mathrm{~mL}$ of $50 \%$ ethanol were added, was equipped with a reflux condenser and a Teflon stir bar. The solution was refluxed for 44 hours, then it was filtered. The solvent was removed by heating on a hot plate. The solid material was extracted with $100 \%$ ethanol. Evaporation of the ethanol yielded crude salt. The percentage yield was estimated to be $85 \frac{8}{2}$, based on the 
weight gain. A later reaction used $23.22 \mathrm{~g}$ (85.68 mmol) adduct, and yielded $20.67 \mathrm{~g}$ crude salt, m.p. $239^{\circ} \mathrm{C}$ (dec). Acid distillation with $1008 \mathrm{H}_{2} \mathrm{SO}_{4}$. A $25 \mathrm{~mL}$ roundbottom flask in which $12.11 \mathrm{~g}(41.2 \mathrm{mmol})$ of the crude sodium salt and $5.0 \mathrm{~g}$ (51 mmol) of $100 \%$ sulfuric acid were mixed was attached to a vacuum distillation apparatus. Distillation was started but the mixture bumped so the reaction was halted and the apparatus was cleaned out. An additional 4.3 $\mathrm{g}_{2} \mathrm{SO}_{4}$ was added and the mixture was distilled. The pressure was maintained, with some difficulty, at about 400 $\mu$. When the temperature reached $75^{\circ} \mathrm{C}$, a white gas began to evolve from the pot and move through the apparatus. The first distillate collected was found to be $\mathrm{H}_{2} \mathrm{SO}_{4}$.

Second run: A $100 \mathrm{~mL}$ roundbottom flask containing $12.95 \mathrm{~g}(44.0 \mathrm{mmol})$ crude salt and $12.77 \mathrm{~g}(130.3 \mathrm{mmol}) \mathrm{H}_{2} \mathrm{SO}_{4}$ was attached to a semimicrodistillation apparatus. After degassing, the mixture was distilled under vacuum. A clear colorless liquid $(3.18 \mathrm{~g})$ was collected at $60^{\circ} \mathrm{C}, 300 \mu$. The liquid was redistilled, and a few drops of clear liquid were collected at $30-35^{\circ} \mathrm{C}, 200-400 \mu$. This liquid showed a singlet in the ${ }^{19} \mathrm{~F}$ NMR spectrum which may indicate an $-\mathrm{SO}_{2} \mathrm{~F}$ group, but did not show any resonances for an $\mathrm{SF}_{5}$ - group.

Acidification using HCl. The sulfonic acid salt (13.16 $\mathrm{g}, 44.8 \mathrm{mmol})$ was dissolved in a small quantity of water. Addition of $10.0 \mathrm{~mL}$ of 12 molar $\mathrm{HCl}$ did not produce a precipitate as expected. More $\mathrm{HCl}$ was added, in stages, 
bringing the total volume to $40 \mathrm{~mL}$, but no precipitation was observed. The volume was reduced to $20-25 \mathrm{~mL}$ by heating on a hot plate, and the solution was put in a $50 \mathrm{~mL} 3$-neck flask. The flask was equipped with a reflux condenser and an $\mathrm{HCl}$ gas bubbler. After excess $\mathrm{HCl}$ was added, a yellow liquid and white precipitate were noted. The mixture was filtered, and the solvent was removed first by heating on a hot plate then by drying under vacuum. The residue was sublimed $\left(100^{\circ} \mathrm{C},<20 \mu\right)$ and $8.13 \mathrm{~g}$ acid hydrate $(28.0 \mathrm{mmol}$, $62.6 \%$ yield) was collected.

Acid neutralization using NaOH. Two samples of the acid $(1.0807 \mathrm{~g}$ and $0.8260 \mathrm{~g})$ were dissolved in water and titrated using a previously standardized $\mathrm{NaOH}$ solution $(0.0999 \mathrm{~N})$. The equivalent weight was found to be $280 \mathrm{~g} / \mathrm{eq}$. which corresponds to a formula of $\mathrm{SF}_{5} \mathrm{CH}_{2} \mathrm{CF}_{2} \mathrm{SO}_{3} \mathrm{H} \cdot 1 / 2 \mathrm{H}_{2} \mathrm{O}$. Activated charcoal was added and the solution was filtered. The water was removed by heating on a hot plate, then by drying on a vacuum line, to recover the sodium salt.

\section{Sunthesis of $\mathrm{SE}_{5} \mathrm{CHFCE}_{2} \mathrm{SO}_{3} \mathrm{H}$}

Reaction using sodium sulfite in $50 \%$ ethanol. A $250 \mathrm{~mL}$ roundbottom flask containing $23.44 \mathrm{~g}(81.11 \mathrm{mmol})$ of $\mathrm{SF}_{5} \mathrm{CHFCF}_{2} \mathrm{Br}$, $10.29 \mathrm{~g}$ (81.67 mmol) of $\mathrm{Na}_{2} \mathrm{SO}_{3}$, and $145 \mathrm{~mL}$ of $50 \%$ ethanol was equipped with a Fredrick condenser, and the mixture was refluxed for 48 hours. The mixture was cooled, and the solvent was removed by heating on a hot plate, with 
final drying done under vacuum. A colorless solid $(27.07 \mathrm{~g})$ was recovered. The solid was extracted with $100 \%$ ethanol, and the extract was dried, yielding $19.76 \mathrm{~g}(63.33 \mathrm{mmol})$ crude $\mathrm{SF}_{5} \mathrm{CHFCF}_{2} \mathrm{SO}_{2} \mathrm{Na}$.

Acidification using $100 \% \mathrm{H}_{2} \mathrm{SO}_{4} . \mathrm{SF}_{5} \mathrm{CHFCF}_{2} \mathrm{Br}(24.07 \mathrm{~g}$, $83.29 \mathrm{mmol}$ ) was dissolved in $76 \mathrm{~mL}$ of $95 \%$ ethanol in a 3-neck flask, while $10.51 \mathrm{~g}$ (83.41 mmol) of $\mathrm{Na}_{2} \mathrm{SO}_{3}$ was dissolved in $57 \mathrm{~mL}$ of water and was placed in a dropping funnel. After the solution was heated to reflux, the $\mathrm{Na}_{2} \mathrm{SO}_{3}$ solution was added over several hours. The mixture was refluxed for 48 hours after the addition was complete. After the solvent was removed, the solid was mixed with 40 $\mathrm{mL}$ of $1008 \mathrm{H}_{2} \mathrm{SO}_{4}$. After degassing, the mixture was refluxed under vacuum, with the pressure maintained between 100 and $200 \mu$, and the oil bath at $120^{\circ} \mathrm{C}$. A white crystalline solid collected in the condenser. The solid was collected and sublimed $\left(60^{\circ} \mathrm{C}, 5 \mu\right)$. The yield was $11.09 \mathrm{~g}$ of the sulfonic acid monohydrate $(36 \mathrm{mmol}, 43 \%), \mathrm{m} . \mathrm{p} .68-70^{\circ} \mathrm{C}$, dec $195^{\circ} \mathrm{C}$.

Acidification using HCl. A $200 \mathrm{~mL} 3$-neck flask containing $19.68 \mathrm{~g}(63.08 \mathrm{mmol})$ of crude $\mathrm{SF}_{5} \mathrm{CHFCF}_{2} \mathrm{SO}_{3} \mathrm{Na}$ dissolved in $100 \mathrm{~mL}$ of water was equipped with a gas inlet and reflux condenser. $\mathrm{HCl}$ was bubbled in until a precipitate formed and the solution was pale yellow-green. The solution was filtered, and the solvent was removed by heating on a hot plate, until the material was an orange slushy solid. Final drying was done under vacuum. The 
solid was sublimed $\left(100^{\circ} \mathrm{C},<40 \mu\right)$ and $7.14 \mathrm{~g}$ of the sulfonic acid monohydrate $(23.2 \mathrm{mmol}, 36.8 \%)$ was collected.

Acid neutralization using $\mathrm{NaOH}$. Two samples of the acid hydrate $(0.7676 \mathrm{~g}$ and $0.4299 \mathrm{~g})$ were dissolved in water. Titration with $0.0999 \mathrm{~N} \mathrm{NaOH}$ required $25.74 \mathrm{~mL}$ and $14.48 \mathrm{~mL}$ respectively. This gave an equivalent weight of $298 \mathrm{~g} / \mathrm{eq}$. (calculated for the acid: $290 \mathrm{~g} / \mathrm{eq}$. and for the monohydrate $308 \mathrm{~g} / \mathrm{eq}$.$) . The solutions were cleaned with$ activated charcoal, filtered, and dried to recover the sodium salt.

At empted synthesis of $\mathrm{SE}_{5} \mathrm{CE}_{2} \mathrm{CF}_{2} \mathrm{SO}_{3} \mathrm{H}$ using iodide adduct Reaction using sodium sulfite in $\mathrm{H}_{2}$ O-dioxane. The iodide adduct ${ }^{35}(15.33 \mathrm{~g}, 43.3 \mathrm{mmol})$ was added to $9.0 \mathrm{~mL}$ of water, $3.0 \mathrm{~mL}$ of dioxane, $0.2 \mathrm{~g}$ of benzoyl peroxide, and $5.63 \mathrm{~g}(44.7 \mathrm{mmol})$ of $\mathrm{Na}_{2} \mathrm{SO}_{3}$ in a nitrogen-flushed flask equipped with a reflux condenser and nitrogen bubbler. The mixture was heated to $80^{\circ} \mathrm{C}$ for 18.5 hours, then cooled to room temperature. The solvent was removed under vacuum. The solid residue was extracted with hot ethyl acetate, but the IR spectrum indicated that both the extract and residue lacked the $\mathrm{SF}_{5}-$ group.

Reaction using sodium sulfite in 50\% ethanol. A 250 $\mathrm{mL}$ roundbottom flask containing $14.59 \mathrm{~g}(41.21 \mathrm{mmol})$ of $\mathrm{SF}_{5} \mathrm{CF}_{2} \mathrm{CF}_{2} \mathrm{I}$, $75 \mathrm{~mL}$ of 50 o ethanol, and $5.36 \mathrm{~g}(42.5 \mathrm{mmol})$ of $\mathrm{Na}_{2} \mathrm{SO}_{3}$ was equipped with a Fredrick condenser. The solution 
was refluxed for 66 hours (changing from bright yellow to orange-brown to black). The mixture was cooled, and the solvent and other volatile materials were removed. The flask was filled with $\mathrm{N}_{2}$ and sealed. The IR spectrum indicated the presence of an $\mathrm{SF}_{5}$ - group in the solid, along with other peaks which were consistent with the structure $\mathrm{SF}_{5} \mathrm{CF}_{2} \mathrm{CF}_{2} \mathrm{SO}_{3} \mathrm{Na}$.

Acidification using $\mathrm{HCl}$. The dirty grey-brown powder from the previous reaction was dissolved in $60 \mathrm{~mL}$ water in a $200 \mathrm{~mL} 3$-neck flask. An $\mathrm{HCl}$ bubbler was attached, and $\mathrm{HCl}$ was added. After precipitate formation, the solution was filtered and the clear colorless solution was put on a hot plate to remove solvent. As the solution became concentrated it turned light green. The slushy solid was transferred to a $35 \mathrm{~mL}$ roundbottom flask and the remaining solvent was removed under vacuum. Some orange solid collected in the trap. A colorless solid (12.81 g) was collected and was re-acidified (15 mL water, $\mathrm{HCl}$ bubbler). The precipitate was filtered and the solvent was removed under vacuum. As the volume decreased, the solution darkened and eventually became a brown-black viscous mass. Attempts to sublime a product out of this mixture were unsuccessful. 
Attempted synthesis of $\mathrm{SE}_{5} \mathrm{CE}_{2} \mathrm{CE}_{2} \mathrm{SO}_{3} \mathrm{H}$ using bromide adduct

Synthesis of $\mathrm{SF}_{5} \mathrm{CE}_{2} \mathrm{CE}_{2} \mathrm{Br}$. A $150 \mathrm{~mL}$ metal vessel containing $35.99 \mathrm{~g}(173.9 \mathrm{mmol})$ of $\mathrm{SF}_{5} \mathrm{Br}$ and $94 \mathrm{mmol}$ of $\mathrm{CF}_{2} \mathrm{CF}_{2}(3.94 \mathrm{~atm}$ in $0.57 \mathrm{~L})$ was put in an oven at $70^{\circ} \mathrm{C}$ for 44 hours. The contents of the vessel were transferred to a $50 \mathrm{~mL}$ roundbottom flask and allowed to warm to room temperature. The liquid was distilled, and the product was collected at $60-62^{\circ} \mathrm{C}$. The yield was $20.21 \mathrm{~g}(65.83 \mathrm{mmol}$, 70 \%) of $\mathrm{SF}_{5} \mathrm{CF}_{2} \mathrm{CF}_{2} \mathrm{Br}$.

Reaction with sodium sulfite in $50 \%$ ethanol. A $250 \mathrm{~mL}$ roundbottom flask containing $20.21 \mathrm{~g}(65.80 \mathrm{mmol})$ of $\mathrm{SF}_{5} \mathrm{CF}_{2} \mathrm{CF}_{2} \mathrm{Br}, 72 \mathrm{~mL}$ of $50 \%$ ethanol, and $10.82 \mathrm{~g}(85.9 \mathrm{mmol})$ of $\mathrm{Na}_{2} \mathrm{SO}_{3}$ was equipped with a Fredrick condenser and a Tefion stir bar. The mixture was refluxed with stirring for 43 hours, then transferred to a beaker and heated on a hot plate to remove the solvent. The damp solid was put on a vacuum line to remove the last bit of solvent. A colorless solid (12.71 g) was recovered.

Acidification attempts. In a $500 \mathrm{~mL}$ roundbottom flask $29.09 \mathrm{~g}(94.76 \mathrm{mmol})$ of $\mathrm{SF}_{5} \mathrm{CF}_{2} \mathrm{CF}_{2} \mathrm{Br}$ was added to $220 \mathrm{~mL}$ of $50 \%$ ethanol. After $12.05 \mathrm{~g}(95.6 \mathrm{mmol})$ of $\mathrm{Na}_{2} \mathrm{SO}_{3}$ was added, the mixture was refluxed for 60 hours. The solvent was removed by heating, and the damp solid was dissolved in 60 $\mathrm{mL}$ of water in a 3-neck flask for acidification. The flask was equipped with a reflux condenser and an HCl bubbler. HCl was added until a precipitate formed, and the mixture 
was filtered. The liquid was evaporated, and the residue was dried under vacuum. A dark, viscous liquid formed. Sublimation of the product mixture was attempted, and it resulted in a small amount of yellow solid which was insoluble in water. The residue was mixed with $80 \mathrm{~mL}$ of $100 \%$ sulfuric acid. After degassing, the mixture was distilled under vacuum. The solution gave puffs of white smoke, but no products.

Acidification using $\mathrm{HCl}$. A $200 \mathrm{~mL} 3$-neck flask containing $12.71 \mathrm{~g}$ of crude salt dissolved in $80 \mathrm{~mL}$ of water was equipped with an $\mathrm{HCl}$ bubbler and a reflux condenser. $\mathrm{HCl}$ was bubbled in as the solution was stirred. The solution became rust-colored, then reddish purple. When a precipitate formed, the solution was peach-red. When $\mathrm{HCl}$ started bubbling vigorously from the solution, the precipitate was yellow/tan and the solution was yellow. The mixture was cooled, filtered, and the volume was reduced by heating on a hot plate. When the volume was about $20 \mathrm{~mL}$, the solution was transferred to a vacuum line. Once again, reduction of the volume gave an intractable liquid.

\section{ELEMENTAL ANALYSIS}

The elemental analyses of $\mathrm{SF}_{5} \mathrm{CH}_{2} \mathrm{CH}_{2} \mathrm{SO}_{3} \mathrm{H}, \mathrm{SF}_{5} \mathrm{CH}_{2} \mathrm{CH}_{2} \mathrm{SO}_{3} \mathrm{Na}$, $\mathrm{SF}_{5} \mathrm{CH}_{2} \mathrm{CF}_{2} \mathrm{SO}_{3} \mathrm{H} \cdot \mathrm{H}_{2} \mathrm{O}, \quad \mathrm{SF}_{5} \mathrm{CH}_{2} \mathrm{CF}_{2} \mathrm{SO}_{3} \mathrm{Na}, \quad \mathrm{SF}_{5} \mathrm{CHFCF}_{2} \mathrm{SO}_{3} \mathrm{H} \cdot \mathrm{H}_{2} \mathrm{O}$, and $\mathrm{SF}_{5} \mathrm{CHFCF}_{2} \mathrm{SO}_{3} \mathrm{Na}$ are tabulated below. Agreement between 
calculated and found values is good. The differences can be explained by the presence of a mixture of hydrates, though the integral hydrates used match the found data well. Most of the fluorine analyses are slightly low, and since the proposed carbene mechanism includes loss of a fluoride, it is possible that minor impurities from this side reaction are still present.

TABLE I

ELEMENTAL ANALYSIS OF SULFONIC ACIDS

\begin{tabular}{|c|c|c|c|}
\hline \multirow[t]{5}{*}{$\mathrm{SF}_{5} \mathrm{CH}_{2} \mathrm{CH}_{2} \mathrm{SO}_{3} \mathrm{H}$} & & Calc. & Eound \\
\hline & $\mathrm{C}$ & 10.17 & 10.26 \\
\hline & $\mathrm{H}$ & 2.12 & 2.32 \\
\hline & $F$ & 40.3 & 39.8 \\
\hline & $\mathrm{S}$ & 27.12 & 27.44 \\
\hline \multicolumn{4}{|l|}{$\mathrm{SE}_{5} \mathrm{CH}_{2} \mathrm{CH}_{2} \mathrm{SO}_{3} \mathrm{Na}$} \\
\hline & $\mathrm{C}$ & 9.30 & 9.38 \\
\hline & $\mathrm{H}$ & 1.55 & 1.51 \\
\hline & $E$ & 36.8 & 36.5 \\
\hline & $S$ & 24.80 & 24.48 \\
\hline \multicolumn{4}{|l|}{$\mathrm{SF}_{5} \mathrm{CH}_{2} \mathrm{CF}_{2} \mathrm{SO}_{3} \mathrm{H} \cdot \mathrm{H}_{2} \mathrm{O}$} \\
\hline & $\mathrm{C}$ & 8.28 & 8.37 \\
\hline & $\mathrm{H}$ & 1.72 & 1.87 \\
\hline & $\mathrm{F}$ & 45.9 & 45.3 \\
\hline & $\mathrm{s}$ & 22.07 & 22.25 \\
\hline
\end{tabular}


TABLE I, cont.

\begin{tabular}{|c|c|c|c|}
\hline \multicolumn{4}{|l|}{$\mathrm{SF}_{5} \mathrm{CH}_{2} \mathrm{CF}_{2} \mathrm{SO}_{3} \mathrm{Na}$} \\
\hline & $\mathrm{C}$ & 8.16 & 8.28 \\
\hline & $\mathrm{H}$ & 0.68 & 0.71 \\
\hline & $\mathrm{F}$ & 45.2 & 44.8 \\
\hline & $\mathrm{s}$ & 21.77 & 21.58 \\
\hline \multicolumn{4}{|l|}{$\mathrm{SF}_{5} \mathrm{CHFCE}_{2} \mathrm{SO}_{3} \mathrm{H} \cdot \mathrm{H}_{2} \mathrm{O}$} \\
\hline & $\mathrm{C}$ & 7.79 & 7.87 \\
\hline & $\underline{\mathrm{H}}$ & 1.30 & 1.30 \\
\hline & $F$ & 49.4 & 48.9 \\
\hline & $\mathrm{S}$ & 20.78 & 20.85 \\
\hline \multicolumn{4}{|l|}{$\mathrm{SF}_{5} \mathrm{CHFCF}_{2} \mathrm{SO}_{3} \mathrm{Na}$} \\
\hline & $\mathrm{C}$ & 7.69 & 7.82 \\
\hline & $\mathrm{H}$ & 0.34 & 0.38 \\
\hline & $\mathrm{F}$ & 48.7 & 48.8 \\
\hline & 5 & 20.51 & 20.64 \\
\hline
\end{tabular}

\section{INFRARED SPECTRA}

Infrared spectral data for $\mathrm{SF}_{5} \mathrm{CH}_{2} \mathrm{CH}_{2} \mathrm{SO}_{3} \mathrm{H}, \mathrm{SF}_{5} \mathrm{CH}_{2} \mathrm{CH}_{2} \mathrm{SO}_{3} \mathrm{Na}$, $\mathrm{SF}_{5} \mathrm{CH}_{2} \mathrm{CF}_{2} \mathrm{SO}_{3} \mathrm{H} \cdot \mathrm{H}_{2} \mathrm{O}$ ， $\mathrm{SF}_{5} \mathrm{CH}_{2} \mathrm{CF}_{2} \mathrm{SO}_{3} \mathrm{Na}, \quad \mathrm{SF}_{5} \mathrm{CHFCF}_{2} \mathrm{SO}_{3} \mathrm{H} \cdot \mathrm{H}_{2} \mathrm{O}$, and $\mathrm{SF}_{5} \mathrm{CHFCF}_{2} \mathrm{SO}_{3} \mathrm{Na}$ are compiled in Tables II through VII, and the spectra are reproduced in the appendix. The most prominent feature of these spectra are the $\mathrm{SF}_{5}-$ symmetric and antisymmetric stretches in the region from 830 to $885 \mathrm{~cm}^{-1} .36$ 
These peaks were used to track these compounds as they were being synthesized and purified. In a few cases these peaks were not easily distinguished, so the $\mathrm{SF}_{5}$ - deformation modes at about $600 \mathrm{~cm}^{-1}$ were used to confirm the presence of this group. The other major peaks are consistent with the assigned structures, with the $\mathrm{SO}_{3}$ symmetric and antisymmetric stretching modes in the region from 1050 to $1100 \mathrm{~cm}^{-1}$ and 1180 to $1280 \mathrm{~cm}^{-1}$ respectively, and the $C F$ stretching modes appearing at slightly higher frequencies, between 1100 and $1300 \mathrm{~cm}^{-1}$. Because of this overlap, unambiguous assignment of the peaks in this region is difficult. The $\mathrm{SO}_{3}$ scissor and wag vibrational modes are visible at 550 to $570 \mathrm{~cm}^{-1}$. The presence of electronegative groups has shifted many of

TABLE II

IR DATA FOR $\mathrm{SF}_{5} \mathrm{CH}_{2} \mathrm{CH}_{2} \mathrm{SO}_{3} \mathrm{H}\left(\mathrm{cm}^{-1}\right)$

\begin{tabular}{|cc|cc|}
\hline peak description* & peak & description \\
\hline 3400 & str, br & 1005 & str \\
\hline 2943 & str, br & 885 & v str \\
\hline 1720 & str, br & 851 & v str \\
\hline 1291 & med & 614 & med \\
\hline 1171 & v str & 576 & str \\
\hline 1069 & med & 454 & med \\
\hline
\end{tabular}

*str= strong, med= medium, br= broad, $v=$ very 
the vibrations to higher frequencies, with the $\mathrm{CH}$ stretching frequencies appearing between 2950 and $3050 \mathrm{~cm}^{-1}$. The $\mathrm{OH}$ stretching and bending modes are also shifted, with the stretch appearing close to $3400 \mathrm{~cm}^{-1}$ and the bend between 1650 and $1750 \mathrm{~cm}^{-1} \cdot 37$

TABLE III

IR DATA FOR $\mathrm{SF}_{5} \mathrm{CH}_{2} \mathrm{CH}_{2} \mathrm{SO}_{3} \mathrm{Na}\left(\mathrm{cm}^{-1}\right)$

\begin{tabular}{|cc|cc|}
\hline peak description & \multicolumn{2}{|c|}{ peak description } \\
\hline 3040 & weak & 993 & med \\
\hline 2987 & v weak & 917 & med \\
\hline 1443 & weak & 833 & v str \\
\hline 1429 & weak & 809 & med \\
\hline 1258 & med & 612 & med \\
\hline 1226 & v str & 574 & str \\
\hline 1193 & v str & 565 & med \\
\hline 1072 & str & 550 & weak \\
\hline 1055 & weak & 531 & med \\
\hline
\end{tabular}


TABLE IV

IR DATA FOR $\mathrm{SF}_{5} \mathrm{CH}_{2} \mathrm{CF}_{2} \mathrm{SO}_{3} \mathrm{H} \cdot \mathrm{H}_{2} \mathrm{O}\left(\mathrm{cm}^{-1}\right)$

\begin{tabular}{|ll|cc|}
\hline peak description & peak description \\
\hline $3490 \quad$ med, br & 991 & str \\
\hline 3038 & weak & 909 & med \\
\hline 2988 & v weak & 896 & med \\
\hline 1653 & med & 855 & str \\
\hline 1420 & med & 834 & v str \\
\hline 1296 & med & 800 & med \\
\hline 1285 & med & 675 & med \\
\hline 1266 & str & 632 & med \\
\hline 1229 & v str & 605 & med \\
\hline 1096 & str & 567 & med \\
\hline 1054 & med & 553 & med \\
\hline
\end{tabular}


TABLE V

IR DATA FOR $\mathrm{SF}_{5} \mathrm{CH}_{2} \mathrm{CF}_{2} \mathrm{SO}_{3} \mathrm{Na}\left(\mathrm{cm}^{-1}\right)$

\begin{tabular}{|c|c|c|c|}
\hline peak & description & peak & description \\
\hline 3116 & weak & 915 & med \\
\hline 3038 & weak & 898 & med \\
\hline 2987 & weak & 856 & $v$ str \\
\hline 1656 & med & 834 & $\mathrm{v}$ str \\
\hline 1420 & str & 800 & med \\
\hline 1337 & weak & 675 & med \\
\hline 1267 & $v$ str & 634 & med \\
\hline 1229 & $\mathrm{v}$ str & 613 & mec \\
\hline 1096 & str & 567 & med \\
\hline 1049 & weak & 552 & med \\
\hline 990 & str & 528 & weak \\
\hline
\end{tabular}


TABLE VI

IR DATA FOR $\mathrm{SF}_{5} \mathrm{CHFCF}_{2} \mathrm{SO}_{3} \mathrm{H} \cdot \mathrm{H}_{2} \mathrm{O}\left(\mathrm{cm}^{-1}\right)$

\begin{tabular}{|cc|cc|}
\hline peak description & peak description \\
\hline 3150 & str, br & 999 & str \\
\hline 3013 & v weak & 859 & v str \\
\hline 2919 & v weak & 812 & med \\
\hline 2851 & v weak & 727 & weak \\
\hline 1730 & str, br & 645 & str \\
\hline 1356 & weak & 598 & str \\
\hline 1269 & str & 568 & str \\
\hline 1231 & v str & 522 & med \\
\hline 1132 & str & 479 & med \\
\hline 1094 & med & 408 & \\
\hline
\end{tabular}


TABLE VII

IR DATA FOR $\mathrm{SF}_{5} \mathrm{CHFCF}_{2} \mathrm{SO}_{3} \mathrm{Na}\left(\mathrm{cm}^{-1}\right)$

\begin{tabular}{|cc|cc|}
\hline peak description & peak description \\
\hline 3674 & str & 1098 & str \\
\hline 3480 & str, br & 1008 & v str \\
\hline 3007 & weak & 919 & str \\
\hline 1653 & med & 859 & v str \\
\hline 1635 & med & 809 & str \\
\hline 1355 & weak & 728 & weak \\
\hline 1285 & v str & 651 & str \\
\hline 1270 & v str & 610 & str \\
\hline 1247 & v str & 599 & str \\
\hline 1154 & str & 571 & str \\
\hline 1131 & str & 531 & med \\
\hline
\end{tabular}

\section{NMR SPECTRA}

The NMR chemical shifts, relative peak areas, and coupling constants for $\mathrm{SF}_{5} \mathrm{CH}_{2} \mathrm{CH}_{2} \mathrm{SO}_{3} \mathrm{H}, \mathrm{SF}_{5} \mathrm{CH}_{2} \mathrm{CH}_{2} \mathrm{SO}_{3} \mathrm{Na}$, $\mathrm{SF}_{5} \mathrm{CH}_{2} \mathrm{CF}_{2} \mathrm{SO}_{3} \mathrm{H} \cdot \mathrm{H}_{2} \mathrm{O}, \quad \mathrm{SF}_{5} \mathrm{CH}_{2} \mathrm{CF}_{2} \mathrm{SO}_{3} \mathrm{Na}, \quad \mathrm{SF}_{5} \mathrm{CFHCF}_{2} \mathrm{SO}_{3} \mathrm{H} \cdot \mathrm{H}_{2} \mathrm{O}$, and $\mathrm{SF}_{5} \mathrm{CFHCF}_{2} \mathrm{SO}_{3} \mathrm{Na}$ are presented in Tables VIII through XIII and the spectra are reproduced in the appendix. In some cases, the coupling constants were not calculated, either because the splitting was not visible or second-order effects made them too difficult to determine. 
TABLE VIII

NMR DATA FOR $\mathrm{F}^{\mathrm{a}}-\mathrm{SF}_{4}{ }^{\mathrm{b}}-\mathrm{CH}_{2}{ }^{\mathrm{c}}-\mathrm{CH}_{2}{ }^{\mathrm{d}}-\mathrm{SO}_{3} \mathrm{H}^{\mathrm{e}}$

\begin{tabular}{|cccccc|}
\hline Chemical shifts & (ppm & from $\mathrm{CFCl}_{3}$ & or & TMS) & and relative areas \\
\hline $\mathrm{a}$ & $\mathrm{b}$ & $\mathrm{C}$ & $\mathrm{d}$ & $\mathrm{e}$ \\
\hline 82.5 & 65.4 & 4.34 & 3.94 & 12.1 \\
\hline 1.0 & 4.1 & 2.0 & 2.0 & 1.0 \\
\hline \multicolumn{6}{c}{ Coupling constant: $\mathrm{J}_{\mathrm{ab}}=145 \mathrm{~Hz}}$. \\
\hline
\end{tabular}

The $\mathrm{SF}_{5}$ - group appears as an $\mathrm{AB}_{4}$ pattern in all of these compounds, with the axial -SF appearing as a nine-line pattern and the equatorial $-\mathrm{SF}_{4}$ - as a broad doublet with fine structure. Line 6 was used as the band center for the axial fluorine, while the midpoint of the integration was chosen as the peak position for the equatorial fluorines. The coupling constant was measured between the centers of the doublet peaks, the center was determined as the midpoint of the rise in the integration curve.

Fluorine chemical shifts reported for these compounds are consistent to those found in similar compounds, 38,39 with axial SF resonances ranging from 84 to $71 \mathrm{ppm}$, equatorial SF resonances from 53 to $72 \mathrm{ppm}, \mathrm{CF}$ at -167 to $-173 \mathrm{ppm}$, and $\mathrm{CF}_{2}$ from -108 to $-125 \mathrm{ppm}$. The proton chemical shifts are shifted downfield as expected, due to the electronegativity of the neighboring fluorines, ${ }^{40}$ with $\mathrm{CH}_{2}$ resonances ranging 
TABIE IX

NMR DATA FOR $\mathrm{F}^{\mathrm{a}}-\mathrm{SF}_{4}{ }^{\mathrm{b}}-\mathrm{CH}_{2}{ }^{\mathrm{c}}-\mathrm{CH}_{2}{ }^{\mathrm{d}}-\mathrm{SO}_{3}-\mathrm{Na}$

Chemical shifts (ppm from $\mathrm{CFCl}_{3}$ or TMS) and relative areas

\begin{tabular}{|cccc|}
\hline $\mathrm{a}$ & $\mathrm{b}$ & $\mathrm{c}$ & $\mathrm{d}$ \\
\hline 84.1 & 65.6 & 4.58 & 3.96 \\
\hline 1.0 & 4.2 & 1.0 & 1.0 \\
\hline
\end{tabular}

Coupling constants: $J_{a b}=144 \mathrm{~Hz}, J_{b c}=7.8 \mathrm{~Hz}$.

from 4 to $5 \mathrm{ppm}$, and $\mathrm{CH}$ resonances at 6.4 to $6.8 \mathrm{ppm}$. The acid peaks for these compounds are far downfield, ranging from $12.1 \mathrm{ppm}$ in $\mathrm{SF}_{5} \mathrm{CH}_{2} \mathrm{CH}_{2} \mathrm{SO}_{3} \mathrm{H}$ to $13.7 \mathrm{ppm}$ in the other two acids. Both acid hydrates exhibit a second peak for the water at $9.2 \mathrm{ppm}$. An NMR spectrum of $\mathrm{SF}_{5} \mathrm{CHFCF}_{2} \mathrm{SO}_{3} \mathrm{H} \cdot \mathrm{H}_{2} \mathrm{O}$ taken after several weeks showed a single peak of relative area three at $10.52 \mathrm{ppm}$ instead of separate acid and water peaks. This would be assigned to water bound to the acid group as $\mathrm{H}_{3} \mathrm{O}+$, rather than as $\mathrm{H}_{2} \mathrm{O}$.

Due to both the size and the electronegativity of the $\mathrm{SF}_{5}-$ and $-\mathrm{SO}_{3}-$ groups, the expected conformation of these compounds has these two groups anti to each other. This makes the NMR spectra more complex than they would otherwise be, as a spin will experience different environments

depending on which side of the molecule it is on. The ${ }^{1} \mathrm{H}$ spin system for $\mathrm{SF}_{5} \mathrm{CH}_{2} \mathrm{CH}_{2} \mathrm{SO}_{3} \mathrm{H}$ is therefore $\mathrm{AA}^{\prime} \mathrm{BB}$ ', rather than $\mathrm{A}_{2} \mathrm{~B}_{2} \cdot 41$ In $\mathrm{SF}_{5} \mathrm{CH}_{2} \mathrm{CF}_{2} \mathrm{SO}_{3} \mathrm{H}$ two different viscinal $\mathrm{J}_{\mathrm{HF}} \mathrm{s}$ are seen, 
TABLE $X$

NMR DATA FOR Fa-SF ${ }_{4}^{b}-\mathrm{CH}_{2}{ }^{\mathrm{c}}-\mathrm{CF}_{2}{ }^{\mathrm{d}}-\mathrm{SO}_{3}-\mathrm{H}^{\mathrm{e}} \cdot \mathrm{H}_{2} \mathrm{O}^{\mathrm{f}}$

Chemical shifts (ppm from $\mathrm{CFCl}_{3}$ or TMS) and relative areas

$\begin{array}{llllll}a & b & c & d & e & f\end{array}$

79.0

72.5

4.78

$-110.3$

13.7

9.2

1.0

4.0

2.0

1.9

1.0

2.0

\begin{tabular}{|c|c|c|c|c|}
\hline & \multicolumn{2}{|c|}{ Coupling constants } & \multicolumn{2}{|l|}{$(\mathrm{Hz})$} \\
\hline & $\mathrm{a}$ & $b$ & $c$ & $\mathrm{~d}$ \\
\hline $\mathrm{a}$ & - & n.a. & n.a. & 2.3 \\
\hline $\mathrm{b}$ & 133 & - & n.a. & n.a. \\
\hline$c$ & $\mathrm{n} \cdot \mathrm{a}$ & 7.7 & - & $17.4,15.9$ \\
\hline $\mathrm{d}$ & 2.2 & 11.8 & $17.8,16.1$ & - \\
\hline
\end{tabular}

one for the gauche interaction and one for the anti

coupling. In $\mathrm{SF}_{5} \mathrm{CHFCF}_{2} \mathrm{SO}_{3} \mathrm{H}$ the presence of the chiral carbon further complicates matters, as the neighboring fluorines will interact with the spins on the chiral center differently.42 Coupling constants for viscinal H-F groups can vary from near zero to $50 \mathrm{~Hz}$, and this coupling varies with the dihedral angle. ${ }^{43}$ This relationship can be used to assign coupling constants, for example in $\mathrm{SF}_{5} \mathrm{CFHCF}_{2} \mathrm{SO}_{3} \mathrm{H},{ }^{3} \mathrm{~J}_{\mathrm{HF}}{ }^{44}$ is near zero for one of the fluorines in the $\mathrm{CF}_{2}$ group, and about $20 \mathrm{~Hz}$ for the other. ${ }^{3} \mathrm{~J}_{\mathrm{HF}}$ is typically near zero for dihedral angles ranging from $65^{\circ}$ to $110^{\circ}$, so the anti 
TABLE XI

NMR DATA FOR Fa- $\mathrm{SF}_{4}{ }^{\mathrm{b}}-\mathrm{CH}_{2}{ }^{\mathrm{c}}-\mathrm{CF}_{2}{ }^{\mathrm{d}}-\mathrm{SO}_{3}-\mathrm{Na}$

Chemical shifts (ppm from $\mathrm{CFCl}_{3}$ or TMS) and relative areas

\begin{tabular}{cccc}
$a$ & $b$ & $c$ & $d$ \\
80.0 & 73.2 & 5.10 & -108.6 \\
1.0 & 3.9 & - & 1.9 \\
\hline
\end{tabular}

Coupling constants $(\mathrm{Hz})$

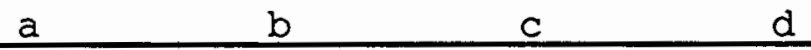

a

n.a.

n.a.

n.a.

b

144

n.a.

n.a.

c

n.a.

n.a.

n.a.

d

2.1

11.9

$15.2,17.8$

fluorine is the one that is observed coupling with the proton and the gauche fluorine has the coupling constant near zero. 
TABLE XII

NMR DATA FOR $\mathrm{F}^{\mathrm{a}}-\mathrm{SF}_{4}{ }^{\mathrm{b}}-\mathrm{CF}^{\mathrm{c}} \mathrm{H}^{\mathrm{d}}-\mathrm{CF}^{\mathrm{e}} \mathrm{F}^{\mathrm{f}}-\mathrm{SO}_{3} \mathrm{H}^{\mathrm{g}} \cdot \mathrm{H}_{2} \mathrm{O}^{\mathrm{h}}$

Chemical shifts (ppm from $\mathrm{CFCl}_{3}$ or TMS) and relative areas

\begin{tabular}{|cccccccc|}
$\mathrm{a}$ & $\mathrm{b}$ & $\mathrm{c}$ & $\mathrm{d}$ & $\mathrm{e}$ & $\mathrm{f}$ & $\mathrm{g}$ & $\mathrm{h}$ \\
\hline 71.1 & 53.0 & -167.3 & 6.39 & -113.9 & -124.9 & 13.68 & 9.2 \\
\hline 1.0 & 4.2 & 1.1 & 1.0 & 1.0 & 1.0 & 1.0 & 2.0 \\
\hline
\end{tabular}

\begin{tabular}{|c|c|c|c|c|c|c|}
\hline \multicolumn{7}{|c|}{ Coupling constants } \\
\hline & a & b & C & $\mathrm{d}$ & e & $\mathrm{f}$ \\
\hline$a$ & - & $\mathrm{n} \cdot \mathrm{a}$ & n.a. & n.a. & n.a. & n.a. \\
\hline$b$ & 144 & $=$ & n.a. & n.a. & n.a. & n.a. \\
\hline C & 2.6 & n.a. & - & 43.2 & 11.9 & 16.9 \\
\hline d & n.a. & 5.1 & 41.4 & - & n.a. & 20.7 \\
\hline e & 1.4 & 15.7 & 12.7 & n.a. & - & 265 \\
\hline$f$ & 1.6 & 11.9 & 16.9 & 20.3 & 262 & - \\
\hline
\end{tabular}


TABLE XIII

NMR DATA FOR $\mathrm{F}^{\mathrm{a}}-\mathrm{SF}_{4}{ }^{\mathrm{b}}-\mathrm{CF}^{\mathrm{c}} \mathrm{H}^{\mathrm{d}}-\mathrm{CF}^{\mathrm{e}} \mathrm{F}^{\mathrm{f}}-\mathrm{SO}_{3} \mathrm{Na}$

Chemical shifts (ppm from $\mathrm{CFCl}_{3}$ or TMS) and relative areas. a

b

C

d

e f

71.2

53.7

$-172.7$

6.79

$-112.5$ $-123.5$

1.0

4.0

1.0

1.1

1.0

\begin{tabular}{|c|c|c|c|c|c|c|}
\hline \multicolumn{7}{|c|}{ Coupling constants } \\
\hline & $a$ & $b$ & C & d & $e$ & $\mathrm{f}$ \\
\hline $\mathrm{a}$ & - & n.a. & n.a. & n.a. & n.a. & n.a. \\
\hline$b$ & 147 & - & n.a. & n.a. & n.a. & n.a. \\
\hline$c$ & 2.6 & n.a. & - & 40.6 & 12.7 & 16.9 \\
\hline$d$ & n.a. & 4.9 & 41.5 & - & n.a. & 20.8 \\
\hline e & 1.7 & 15.2 & 11.8 & n.a. & - & 266 \\
\hline $\mathrm{f}$ & 1.7 & 11.8 & 17.3 & 20.3 & 266 & - \\
\hline
\end{tabular}

\section{MASS SPECTRA}

The mass spectra of $\mathrm{SF}_{5} \mathrm{CH}_{2} \mathrm{CH}_{2} \mathrm{SO}_{3} \mathrm{H}$, $\mathrm{SF}_{5} \mathrm{CH}_{2} \mathrm{CF}_{2} \mathrm{SO}_{3} \mathrm{H} \cdot \mathrm{H}_{2} \mathrm{O}$, and $\mathrm{SF}_{5} \mathrm{CHFCF}_{2} \mathrm{SO}_{3} \mathrm{H} \cdot \mathrm{H}_{2} \mathrm{O}$ are reported in Tables XIV through XVI. The data are similar for the three compounds, especially in the lower molecular weight fragments. Fragments at $\mathrm{M} / \mathrm{e}$ values of $127\left(\mathrm{SF}_{5}+\right), 89\left(\mathrm{SF}_{3}+\right), 70\left(\mathrm{SF}_{2}+\right)$, and $51(\mathrm{SF}+)$ provide strong evidence for the presence of the $\mathrm{SF}_{5}-$ group in 
all three acids. The $\mathrm{SF}_{3}+$ fragment is the base peak for all three, and none of the three show a molecular ion. The remainder of the fragmentation patterns are consistent with the structures assigned to these compounds.

TABLE XIV

MASS SPECTRUM OF $\mathrm{SF}_{5} \mathrm{CH}_{2} \mathrm{CH}_{2} \mathrm{SO}_{3} \mathrm{H}$

\begin{tabular}{|c|c|c|c|c|c|}
\hline $\mathrm{M} / \mathrm{e}$ & Rel. Int. & Type & $\mathrm{M} / \mathrm{e}$ & Rel. Int. & Type \\
\hline 43.0 & 11.7 & $\mathrm{C}_{2} \mathrm{~F}+$ & 69.9 & 6.8 & $\mathrm{SF}_{2}+$ \\
\hline 44.0 & 3.8 & $\mathrm{Cs}+$ & 79.9 & 6.3 & $\mathrm{SO}_{3}+$ \\
\hline 45.0 & 99.5 & $\mathrm{HCS}+$ & 80.9 & 17.5 & $\mathrm{SO}_{3} \mathrm{H}+$ \\
\hline 46.0 & 3.3 & $\mathrm{H}_{2} \mathrm{CS}+$ & 81.9 & 4.9 & $\mathrm{CSF}_{2}+$ \\
\hline 47.0 & 72.0 & $\mathrm{C}_{2} \mathrm{H}_{4} \mathrm{~F}+$ & 88.9 & 100.0 & $\mathrm{SF}_{3}+$ \\
\hline 47.9 & 9.0 & SOt & 90.0 & 4.5 & ${ }^{34} \mathrm{SF}_{3}+$ \\
\hline 51.0 & 2.7 & $\mathrm{SF}+$ & 108.9 & 16.7 & $\mathrm{C}_{2} \mathrm{H}_{4} \mathrm{SO}_{3} \mathrm{H}+$ \\
\hline 63.9 & 9.6 & $\mathrm{SO}_{2}+$ & 110.9 & 3.6 & $\mathrm{FSCH}_{2} \mathrm{CH}_{2} \mathrm{~S}+$ \\
\hline 64.9 & 63.3 & $\mathrm{SO}_{2} \mathrm{H}+, \mathrm{H}_{2} \mathrm{CSF}+$ & 126.8 & 17.0 & $\mathrm{SF}_{5}+$ \\
\hline 66.9 & 6.8 & $\mathrm{SOF}+, \mathrm{SOH}_{3} \mathrm{O}+$ & 134.8 & 8.5 & $\mathrm{SF}_{4} \mathrm{C}_{2} \mathrm{H}_{3}+$ \\
\hline
\end{tabular}


TABLE XV

MASS SPECTRUM OF $\mathrm{SF}_{5} \mathrm{CH}_{2} \mathrm{CF}_{2} \mathrm{SO}_{3} \mathrm{H} \cdot \mathrm{H}_{2} \mathrm{O}$

\begin{tabular}{|c|c|c|c|c|c|}
\hline $\mathrm{M} / \mathrm{e}$ & Rel. Int. & Type & $\mathrm{M} / \mathrm{e}$ & Rel. Int. & Type \\
\hline 41.0 & 3.1 & $\mathrm{C}_{2} \mathrm{OH}+$ & 69.9 & 8.2 & $\mathrm{SF}_{2}+$ \\
\hline 44.0 & 8.0 & $\mathrm{CSt}$ & 79.9 & 8.4 & $\mathrm{SO}_{3}+$ \\
\hline 45.0 & 14.6 & $\mathrm{HCS}+$ & 80.9 & 16.1 & $\mathrm{CH}_{2} \mathrm{CF}_{2} \mathrm{OH}+$ \\
\hline 47.9 & 11.3 & $\mathrm{SO}$ & 82.9 & 92.5 & $\mathrm{HCSF}_{2}+$ \\
\hline 51.0 & 4.4 & $\mathrm{SE}+$ & 88.9 & 100.0 & $\mathrm{SF}_{3}+$ \\
\hline 57.0 & 4.2 & $\mathrm{SC}_{2} \mathrm{H}+$ & 90.9 & 4.1 & ${ }^{34} \mathrm{SF}_{3}+$ \\
\hline 61.0 & 21.5 & $\mathrm{HCCFOH}+$ & 126.8 & 30.1 & $\mathrm{SF}_{5}+$ \\
\hline 63.0 & 6.5 & $\mathrm{CSF}+$ & 148.9 & 10.2 & $\mathrm{SF}_{5} \mathrm{CHCOH}+$ \\
\hline 63.9 & 50.9 & $\mathrm{HCSF}+$ & 168.8 & 3.1 & $\mathrm{SF}_{5} \mathrm{CH}_{2} \mathrm{CFOH}+$ \\
\hline 64.9 & 28.2 & $\mathrm{H}_{2} \mathrm{CSF}+$ & 190.8 & 94.3 & $\mathrm{SF}_{5} \mathrm{CH}_{2} \mathrm{CF}_{2}+$ \\
\hline 66.9 & 2.9 & $\mathrm{SOF}+, \mathrm{SOH}_{3} \mathrm{O}+$ & 192.8 & 4.1 & ${ }^{34} \mathrm{SF}_{5} \mathrm{CH}_{2} \mathrm{CF}_{2}+$ \\
\hline
\end{tabular}


TABLE XVI

MASS SPECTRUM OF $\mathrm{SF}_{5} \mathrm{CHFCF}_{2} \mathrm{SO}_{3} \mathrm{H} \cdot \mathrm{H}_{2} \mathrm{O}$

\begin{tabular}{|c|c|c|c|c|c|}
\hline $\mathrm{M} / \mathrm{e}$ & Rel. Int & Type & $M / e$ & Re1. Int. & Type \\
\hline 43.9 & 5.2 & $\mathrm{CS}+$ & 69.8 & 5.5 & $\mathrm{SF}_{2}+$ \\
\hline 44.9 & 6.9 & $\mathrm{HCS}+$ & 78.8 & 8.9 & $\mathrm{C}_{2} \mathrm{~F}_{2} \mathrm{OH}+$ \\
\hline 47.9 & 7.4 & $\mathrm{SO}+$ & 79.8 & 4.5 & $\mathrm{SO}_{3}+$ \\
\hline 48.9 & 12.0 & $\mathrm{SOH}+$ & 80.8 & 14.0 & $\mathrm{C}_{2} \mathrm{~F}_{3}+, \mathrm{HSO}_{3}+$ \\
\hline 50.9 & 43.9 & $\mathrm{SF}+$ & 81.8 & 18.4 & $\mathrm{CFHCF}_{2}+$ \\
\hline 60.9 & 6.6 & $\mathrm{CHCFOH}+$ & 82.8 & 29.1 & $\mathrm{HCSF}_{2}+$ \\
\hline 62.9 & 6.2 & $\mathrm{CHCF}_{2}+$ & 88.8 & 100.0 & $\mathrm{SF}_{3}+$ \\
\hline 63.8 & 18.6 & $\mathrm{SO}_{2}+, \mathrm{HFCS}+$ & 100.8 & 25.5 & $\mathrm{SF}_{3} \mathrm{C}+$ \\
\hline 64.8 & 36.5 & $\mathrm{HSO}_{2}+$ & 126.7 & 17.4 & $\mathrm{SF}_{5}+$ \\
\hline 66.8 & 2.9 & $\mathrm{SOF}+, \mathrm{SOH}_{3} \mathrm{O}+$ & 190.6 & 21.8 & $\mathrm{SF}_{5} \mathrm{CHCF}_{2} \mathrm{H}+$ \\
\hline
\end{tabular}

Mass spectral data for $\mathrm{SF}_{5} \mathrm{CH}_{2} \mathrm{CH}_{2} \mathrm{SO}_{3} \mathrm{Na}, \mathrm{SF}_{5} \mathrm{CH}_{2} \mathrm{CF}_{2} \mathrm{SO}_{3} \mathrm{Na}$, and $\mathrm{SF}_{5} \mathrm{CHFCF}_{2} \mathrm{SO}_{3} \mathrm{Na}$ are given in Tables XVII to XIX. All three spectra were run using fast atom bombardment in a glycerol matrix, which is the preferred method for ionic, multifunctional molecules. ${ }^{45}$ As with the acids, the three sets of fragmentation patterns are similar, especially at low M/e. All three show many peaks with M/e greater than the calculated molecular weight, including prominent peaks at $\mathrm{M}+\mathrm{Na}+$ and $2 \mathrm{M}+\mathrm{Nat}$, which are typical for the method being used. ${ }^{46}$ There are also additional peaks at $\mathrm{M} / \mathrm{e}=43,57$, and 75 which are from the glycerol.47,48 Unidentified peaks may 
be the result of combinations of salt and glycerol fragments. The peaks indicating the $\mathrm{SF}_{5}$ - group are not as apparent, as only the $\mathrm{SF}_{3}+$ fragment has an appreciable intensity.

TABLE XVII

MASS SPECTRUM OF $\mathrm{SF}_{5} \mathrm{CH}_{2} \mathrm{CH}_{2} \mathrm{SO}_{3} \mathrm{Na}$

\begin{tabular}{|c|c|c|c|c|c|}
\hline $\mathrm{M} / \mathrm{e}$ & Rel. Int. & Type & $\mathrm{M} / \mathrm{e}$ & Rel. Int & Type \\
\hline 42.9 & 9.2 & $\mathrm{C}_{2} \mathrm{H}_{3} \mathrm{O}+$ & 148.6 & 4.8 & $\mathrm{SF}_{3} \mathrm{CH}_{2} \mathrm{CH}_{2} \mathrm{~S}+$ \\
\hline 43.9 & 3.0 & CSt & 152.7 & 7.2 & $\mathrm{SF}_{5} \mathrm{C}_{2} \mathrm{H}_{2}+$ \\
\hline 44.9 & 9.2 & $\mathrm{HCS}+$ & 154.7 & 4.4 & $\mathrm{SF}_{5} \mathrm{C}_{2} \mathrm{H}_{4}+$ \\
\hline 56.9 & 8.4 & $\mathrm{C}_{3} \mathrm{H}_{5} \mathrm{O}+$ & 170.8 & 3.3 & $\mathrm{CFHCHSO}_{3} \mathrm{Na}_{2}+$ \\
\hline 60.8 & 4.3 & $\mathrm{HCSO}+$ & 280.5 & 75.1 & $\mathrm{M}+\mathrm{Na}+$ \\
\hline 62.8 & 10.2 & CSEt & 282.5 & 7.7 & ${ }^{34} \mathrm{~S}-\mathrm{M}+\mathrm{Na}+$ \\
\hline 64.8 & 48.5 & $\mathrm{CH}_{2} \mathrm{SF}+$ & 322.4 & 3.5 & $?$ \\
\hline 74.8 & 4.0 & $\mathrm{C}_{3} \mathrm{H}_{7} \mathrm{O}_{2}+$ & 372.5 & 6.5 & $?$ \\
\hline 88.7 & 6.6 & $\mathrm{SF}_{3}+$ & 383.4 & 4.1 & $?$ \\
\hline 104.7 & 4.1 & $\mathrm{HC}_{2} \mathrm{SO}_{3}+$ & 537.4 & 18.9 & $2 \mathrm{M}+\mathrm{Na}+$ \\
\hline 114.7 & 100.0 & $\mathrm{CSO}_{3} \mathrm{Na}+$ & 539.52 & 3.6 & $?$ \\
\hline 125.6 & 12.0 & $\mathrm{Na}_{2} \mathrm{SO}_{3}+$ & 579.8 & 2.6 & $?$ \\
\hline 136.7 & 24.8 & $\mathrm{SF}_{4} \mathrm{C}_{2} \mathrm{H}_{3}+$ & 798.5 & 3.2 & ? \\
\hline
\end{tabular}


TABLE XVIII

MASS SPECTRUM OF $\mathrm{SF}_{5} \mathrm{CH}_{2} \mathrm{CF}_{2} \mathrm{SO}_{3} \mathrm{Na}$

\begin{tabular}{|c|c|c|c|c|c|}
\hline $\mathrm{M} / \mathrm{e}$ & Rel. Int. & Type & $\mathrm{M} / \mathrm{e}$ & Rel.Int. & Type \\
\hline 42.9 & 15.5 & $\mathrm{C}_{2} \mathrm{H}_{3} \mathrm{O}+$ & 136.8 & 26.7 & $\mathrm{SF}_{4} \mathrm{C}_{2} \mathrm{H}_{3}+$ \\
\hline 44.9 & 10.8 & HCSt & 148.7 & 11.7 & $\mathrm{HCCFSO}_{3} \mathrm{Na}+$ \\
\hline 56.9 & 17.4 & $\mathrm{C}_{2} \mathrm{H}_{5} \mathrm{O}+$ & 164.7 & 4.3 & $\mathrm{CF}_{2} \mathrm{HSO}_{3} \mathrm{Na}+$ \\
\hline 60.9 & 5.9 & $\mathrm{HCSO}+$ & 170.8 & 5.6 & $\mathrm{SF}_{5} \mathrm{CHCF}+$ \\
\hline 62.8 & 17.3 & $\mathrm{CSF}+$ & 190.7 & 11.6 & $\mathrm{SF}_{5} \mathrm{CH}_{2} \mathrm{CF}_{2}+$ \\
\hline 64.8 & 100.0 & $\mathrm{H}_{2} \mathrm{CSF}+$ & 214.8 & 10.6 & $\mathrm{CF}_{2} \mathrm{HCF}_{2} \mathrm{SO}_{3} \mathrm{Na}+$ \\
\hline 74.8 & 5.8 & $\mathrm{C}_{3} \mathrm{H}_{7} \mathrm{O}_{2}+$ & 296.6 & 5.9 & $317-\mathrm{HF}+$ \\
\hline 88.7 & 16.6 & $\mathrm{SF}_{3}+$ & 316.5 & 66.2 & $\mathrm{M}+\mathrm{Na}+$ \\
\hline 104.7 & 6.3 & $\mathrm{C}_{2} \mathrm{SO}_{3}+$ & 318.5 & 6.2 & ${ }^{34} \mathrm{~S}+$ \\
\hline 106.7 & 86.8 & $\mathrm{HC}_{2} \mathrm{SO}_{3}+$ & 358.5 & 2.6 & $?$ \\
\hline 114.8 & 68.8 & $\mathrm{CSO}_{3} \mathrm{Na}+$ & 418.2 & 2.5 & $-\mathrm{SF}_{4}, 2 \mathrm{HF}, \mathrm{SO}_{2}$ \\
\hline 125.7 & 21.0 & $\mathrm{Na}_{2} \mathrm{SO}_{3}+$ & 610.0 & 3.8 & $2 \mathrm{M}+\mathrm{Na}+$ \\
\hline
\end{tabular}


TABLE XIX

MASS SPECTRUM OF $\mathrm{SF}_{5} \mathrm{CHFCF}_{2} \mathrm{SO}_{3} \mathrm{Na}$

\begin{tabular}{|c|c|c|c|c|c|}
\hline $\mathrm{M} / \mathrm{e}$ & Rel. Int. & Type & $\mathrm{M} / \mathrm{e}$ & Rel.Int & Type \\
\hline 40.9 & 2.5 & $\mathrm{C}_{2} \mathrm{OH}+$ & 114.8 & 100.0 & $\mathrm{CSO}_{3} \mathrm{Na}+$ \\
\hline 42.9 & 12.3 & $\mathrm{C}_{2} \mathrm{H}_{3} \mathrm{O}+$ & 115.8 & 7.2 & $\mathrm{CFHCF}_{2} \mathrm{~S}+$ \\
\hline 43.9 & 4.4 & $\mathrm{CS}+$ & 125.7 & 10.4 & $\mathrm{Na}_{2} \mathrm{SO}_{3}+$ \\
\hline 44.9 & 18.7 & $\mathrm{HCS}+$ & 136.8 & 19.1 & $\mathrm{SF}_{4} \mathrm{C}_{2} \mathrm{H}_{3}$ \\
\hline 56.9 & 16.0 & $\mathrm{C}_{3} \mathrm{H}_{5} \mathrm{O}+$ & 156.8 & 3.9 & $\mathrm{CF}_{2} \mathrm{SO}_{2} \cdot \mathrm{C}_{3} \mathrm{H}_{7} \mathrm{O}_{2}+$ \\
\hline 60.9 & 6.6 & $\mathrm{HCSO}+$ & 170.8 & 6.4 & $\mathrm{CH}_{2} \mathrm{CFSO}_{3} \mathrm{Na}_{2}+$ \\
\hline 64.8 & 19.6 & $\mathrm{H}_{2} \mathrm{CSF}+$ & 188.8 & 3.7 & $\mathrm{SF}_{5} \mathrm{CFCF}+$ \\
\hline 74.8 & 12.8 & $\mathrm{C}_{3} \mathrm{H}_{7} \mathrm{O}_{2}+$ & 206.8 & 13.6 & $\mathrm{CFCF}_{2} \mathrm{SO}_{3} \mathrm{Na}_{2}+$ \\
\hline 88.7 & 5.6 & $\mathrm{SF}_{3}+$ & 212.8 & 2.9 & $?$ \\
\hline 92.8 & 17.6 & CFCFS+ & 217.7 & 4.8 & $\mathrm{Na}_{2} \mathrm{SO}_{3} \cdot \mathrm{C}_{3} \mathrm{H}_{8} \mathrm{O}_{3}+$ \\
\hline 96.8 & 4.0 & $\mathrm{H}_{2} \mathrm{CSO}_{2}+$ & 334.5 & 46.3 & $\mathrm{M}+\mathrm{Na}+$ \\
\hline 104.7 & 2.5 & $\mathrm{C}_{2} \mathrm{SO}_{3}+$ & 425.0 & 16.1 & $?$ \\
\hline 113.8 & 3.8 & $\mathrm{CF}_{2} \mathrm{SO}_{2}+$ & 645.9 & 5.3 & $2 \mathrm{M}+\mathrm{Na}+$ \\
\hline
\end{tabular}




\section{CHAPTER 4 \\ OTHER REACTIONS}

\section{DISCUSSION}

This chapter includes reactions that are not a part of the main project. The first of these is the attempted synthesis of $\left(\mathrm{CF}_{3} \mathrm{SO}_{2}\right)_{2} \mathrm{CHSO}_{3} \mathrm{H}$ by $\mathrm{SO}_{3}$ insertion into the sodium salt $\left(\mathrm{CF}_{3} \mathrm{SO}_{2}\right)_{2} \mathrm{CHNa} .49$ While the salt synthesis went well, the $\mathrm{SO}_{3}$ insertion did not, as not only was there no weight gain as expected, but the weight was down slightly, indicating decomposition had occurred.

Sulfonation of the iodide $\mathrm{CF}_{3} \mathrm{CH}_{2} \mathrm{I}$ was tried by both the Strecker reaction and sodium sulfite in $50 \%$ ethanol. In neither case was there any evidence that a reaction had occurred, possibly because the inductive effect of the $\mathrm{CF}_{3}$ group stabilized the C-I bond.

A route to $\mathrm{C}\left(\mathrm{SCH}_{3}\right)_{4}$ was known, 50 so the oxidation of $\left(\mathrm{CH}_{3} \mathrm{~S}\right)_{3} \mathrm{CH}$, which is commercially available, was attempted to see if the tris sulfonyl chloride would result. ${ }^{51}$

Unfortunately, methanesulfonyl chloride was recovered instead.

A new $\mathrm{SF}_{5} \mathrm{Br}$ adduct and telomer were synthesized by addition of $\mathrm{SF}_{5} \mathrm{Br}$ to $\mathrm{CF}_{2}=\mathrm{CFBr}$. The procedure was similar to that used for the tri- and tetra- fluoroethylene adducts. 
The remainder of this chapter contains the procedure for the reactions mentioned here, as well as the elemental analysis, IR spectra, NMR spectra, and mass spectra for these new compounds.

\section{EXPERIMENTAL}

Synthesis of $\left(\mathrm{CF}_{3} \mathrm{SO}_{2} \perp_{2} \mathrm{CHNa}\right.$

$\left(\mathrm{CF}_{3} \mathrm{SO}_{2}\right)_{2} \mathrm{CH}_{2}(4.00 \mathrm{~g}, 14.7 \mathrm{mmol})$ was dissolved in $20 \mathrm{~mL}$ of methanol. The solution was neutralized with $\mathrm{Na}_{2} \mathrm{CO}_{3}$ until bubbling ceased. A total of $0.92 \mathrm{~g}(8.7 \mathrm{mmol})$ sodium carbonate was used. The solution was filtered, the solvent was evaporated, and the damp solid was dried on a vacuum line. The crude salt $(4.2 \mathrm{~g})$ was recovered, m.p. $255-258^{\circ} \mathrm{C}$ (dec) .

\section{Attempted Synthesis of $\left(\mathrm{CF}_{3} \mathrm{SO}_{2} \mathrm{~L}_{2} \mathrm{CHSO}_{3} \mathrm{Na}\right.$}

The Na salt $(3.9 \mathrm{~g}, 13.3 \mathrm{mmol})$ was transferred to a 100 $\mathrm{mL}$ glass reaction vessel. Sulfur trioxide $(3.28 \mathrm{~g}, 41.1$ mmol) was added, and the mixture was heated to $85-90^{\circ} \mathrm{C}$ for a total of 8 hours, after which the unreacted $\mathrm{SO}_{3}$ was pumped off. Weight gain indicated that the reaction was not complete, so more $\mathrm{SO}_{3}$ was added (1.40 $\mathrm{g}$ additional) and the mixture was reheated to $90^{\circ} \mathrm{C}$ for 2 days. The vessel was cooled to $-196^{\circ} \mathrm{C}$, and volatile materials were removed under vacuum. There was no net weight gain, so the reaction was abandoned. 
Reaction of $\mathrm{CE}_{3} \mathrm{CH}_{2}$ I with $\mathrm{Na}_{2} \mathrm{SO}_{3}$

A $150 \mathrm{~mL}$ metal reaction vessel containing $12.5 \mathrm{~g}(99.2$ mmol) of $\mathrm{Na}_{2} \mathrm{SO}_{3}, 22.5 \mathrm{~g}(107 \mathrm{mmol})$ of $\mathrm{CF}_{3} \mathrm{CH}_{2} \mathrm{I}$ and $60 \mathrm{~mL}$ of water was put in an oil bath at $125^{\circ} \mathrm{C}$ for 24 hours with frequent shaking. When the vessel was opened, the reactants were recovered unchanged.

Reaction of $\left(\mathrm{CH}_{3} \mathrm{~S}\right)_{3} \mathrm{CH}$ with $\mathrm{Cl}_{2} / \mathrm{H}_{2} \mathrm{O}$

Water $(40 \mathrm{~mL})$ and $\left(\mathrm{CH}_{3} \mathrm{~S}\right)_{3} \mathrm{CH}(4.9 \mathrm{~g}, 31.8 \mathrm{mmol})$ were added to a $100 \mathrm{ml}$ flask equipped with a thermometer, dry ice/acetone reflux condenser, and a gas inlet tube for $\mathrm{Cl}_{2}$. Chlorine was added slowly, until further addition of $\mathrm{Cl}_{2}$ caused no further reaction. Methylene chloride was added, the layers were separated, and the organic layer was dried with $\mathrm{MgSO}_{4}$ then distilled under reduced pressure (20 torr). A clear yellow liquid $(3.78 \mathrm{~g})$ was collected at $72-73^{\circ} \mathrm{C}, 21$ torr. This was found to be $\mathrm{CH}_{3} \mathrm{SO}_{2} \mathrm{Cl}$, from the IR spectrum.

\section{Reaction of $\mathrm{SE}_{5} \mathrm{Br}$ with $\mathrm{CE}_{2} \equiv \mathrm{CEBr}$}

A $150 \mathrm{~mL}$ metal vessel containing $26.45 \mathrm{~g}$ (127.8 mmol) of $\mathrm{SF}_{5} \mathrm{Br}$ and $45 \mathrm{mmol} \mathrm{CF}_{2}=\mathrm{CFBr}(\mathrm{V}=1.57 \mathrm{~L}, \mathrm{P}=1.89$ atm) was warmed in hot water. The vessel was placed in an oven at $67^{\circ} \mathrm{C}$ for 51 hours. The contents of the vessel were transferred to a $50 \mathrm{~mL}$ roundbottom flask, and allowed to warm to room temperature. Distillation of the mixture yielded $\mathrm{SF}_{5} \mathrm{CF}_{2} \mathrm{CFBr}_{2}$ mixed with other minor components. Preparative gas chromatography of the distillate yielded 
$22.94 \mathrm{~g}$ (62.3 mol, $48.8 \%$ yield) pure $\mathrm{SF}_{5} \mathrm{CF}_{2} \mathrm{CFBr}_{2}$. The reaction vessel was rinsed with acetone, and the rinsings were set aside to dry. The $3.83 \mathrm{~g}(2.11 \mathrm{mmol}, 46.8 \%$ yield) solid material that was collected from these rinsings was the telomer $\mathrm{SF}_{5}\left(\mathrm{CF}_{2} \mathrm{CFBr}\right)_{10} \mathrm{Br}$.

Reaction of $\mathrm{CF}_{3} \mathrm{CH}_{2}$ I with $\mathrm{Na}_{2} \mathrm{SO}_{3}$ in $50 \%$ ethanol

A $250 \mathrm{~mL}$ roundbottom flask containing $24.92 \mathrm{~g}$ (118.7 mmol) of $\mathrm{CF}_{3} \mathrm{CH}_{2} \mathrm{I}, 144 \mathrm{~mL}$ of $50 \%$ ethanol and $15.04 \mathrm{~g}$ (119.4 mmol) of $\mathrm{Na}_{2} \mathrm{SO}_{3}$ was equipped with a Fredrick condenser and a Teflon stir bar. The solution was refluxed for 3 days, then it was cooled. The mixture was transferred to a beaker and the solvent was removed by heating on a hot plate. Final drying was done under vacuum, without heating. A colorless solid (15.82 g) was obtained, but the minor weight gain indicated that little if any reaction had occurred.

\section{ELEMENTAL ANALYSIS}

The elemental analyses for $\mathrm{SF}_{5} \mathrm{CF}_{2} \mathrm{CFBr}_{2}$ and $\mathrm{SF}_{5}\left(\mathrm{CF}_{2} \mathrm{CFBr}\right)_{10} \mathrm{Br}$ are given below. The data for the monomer correspond to the calculated values closely, while the different chain lengths present in the telomer make matching the found percentages more difficult. 
TABLE $X X$

ELEMENTAL ANALYSIS FOR $\mathrm{SF}_{5} \mathrm{CF}_{2} \mathrm{CFBr}_{2}$ AND $\mathrm{SF}_{5}\left(\mathrm{CF}_{2} \mathrm{CFBr}\right)_{10} \mathrm{Br}$

\begin{tabular}{|c|c|c|c|}
\hline \multirow[t]{6}{*}{$\mathrm{SF}_{5} \mathrm{CF}_{2} \mathrm{CFBr}_{2}$} & & Calc. & Found \\
\hline & $\mathrm{C}$ & 6.52 & 6.48 \\
\hline & $\mathrm{H}$ & 0.0 & $<0.1$ \\
\hline & $\mathrm{F}$ & 41.3 & 41.5 \\
\hline & $\mathrm{Br}$ & 43.47 & 43.43 \\
\hline & $S$ & 8.70 & 8.59 \\
\hline \multicolumn{4}{|c|}{$\mathrm{SF}_{5}\left(\mathrm{CF}_{2} \mathrm{CFBr}\right)_{10} \mathrm{Br}$} \\
\hline & $\mathrm{C}$ & 13.22 & 13.56 \\
\hline & $\mathrm{H}$ & 0.0 & $<0.1$ \\
\hline & $F$ & 36.6 & 37.1 \\
\hline & $\mathrm{Br}$ & 48.39 & 47.53 \\
\hline & $S$ & 1.77 & 1.85 \\
\hline
\end{tabular}

IR SPECTRA

IR spectral data for $\mathrm{SF}_{5} \mathrm{CF}_{2} \mathrm{CFBr} r_{2}$ and $\mathrm{SF}_{5}\left(\mathrm{CF}_{2} \mathrm{CFBr}\right)_{10} \mathrm{Br}$ are summarized in Tables XXI and XXII below and the spectra are reproduced in the appendix. Both spectra exhibit a strong $\mathrm{SF}_{5}-$ vibrational mode in the region 850 to $910 \mathrm{~cm}^{-1}$, and $\mathrm{CF}$ stretching frequencies between 1100 and $1210 \mathrm{~cm}^{-1}$. Deformation modes for $\mathrm{SF}_{5}$ - appear near $600 \mathrm{~cm}^{-1}$ for both the monomer and telomer. 
TABLE XXI

IR DATA FOR $\mathrm{SF}_{5} \mathrm{CF}_{2} \mathrm{CFBr}_{2}\left(\mathrm{~cm}^{-1}\right)$

\begin{tabular}{|c|c|c|c|}
\hline peak & desc. & peak & desc. \\
\hline 1208 & str & 811 & weak \\
\hline 1118 & str & 717 & str \\
\hline 1031 & weak & 686 & med \\
\hline 903 & $\mathrm{v}$ str & 643 & weak \\
\hline 886 & $\mathrm{v}$ str & 602 & str \\
\hline 828 & med & 575 & weak \\
\hline
\end{tabular}

TABLE XXII

IR DATA FOR $\mathrm{SF}_{5}\left(\mathrm{CF}_{2} \mathrm{CFBr}\right)_{10} \mathrm{Br}\left(\mathrm{cm}^{-1}\right)$

\begin{tabular}{|cc|cc|}
\hline peak & desc. & peak & desc. \\
\hline 1411 & med & 796 & weak \\
\hline 1384 & med & 763 & med \\
\hline 1249 & str & 712 & med \\
\hline 1208 & v str & 683 & med \\
\hline 1183 & v str & 653 & med \\
\hline 1122 & vs & 636 & w \\
\hline 1115 & m & 599 & s \\
\hline 927 & s & 573 & m \\
\hline 884 & vs & 532 & w \\
\hline 841 & s & 495 & w \\
\hline
\end{tabular}




\section{${ }^{19}$ F NMR SPECTRA}

NMR data for $\mathrm{SF}_{5} \mathrm{CF}_{2} \mathrm{CFBr}_{2}$ and $\mathrm{SF}_{5}\left(\mathrm{CF}_{2} \mathrm{CFBr}\right)_{10} \mathrm{Br}$ are given in Tables XXIII and XXIV, and the spectra are reproduced in the appendix. The spectra exhibit an $\mathrm{AB}_{4}$ pattern for the $\mathrm{SF}_{5}-$ group, with a 9-line pattern at about $65 \mathrm{ppm}$, and a doublet with fine structure at about $50 \mathrm{ppm}$. These are within the expected range for these resonances. The monomer shows a $C F$ resonance at about $-86 \mathrm{ppm}$, while the $\mathrm{CF}_{2}$ peak is at $-78 \mathrm{ppm}$. The polymer shows a series of broad peaks of different sizes in this region, as would be expected for the many different $\mathrm{CF}_{2}$ and $\mathrm{CF}$ groups present in the telomer.

\section{Table XXIII}

NMR DATA FOR $\mathrm{F}^{\mathrm{a}}-\mathrm{SF}_{4}{ }^{\mathrm{b}}-\mathrm{CF}_{2}{ }^{\mathrm{c}}-\mathrm{CF}^{\mathrm{d}} \mathrm{Br}_{2}$

Chemical shifts (from $\mathrm{CFCl}_{3}$ ) and relative areas.

\begin{tabular}{|cccc|}
\hline $\mathrm{a}$ & $\mathrm{b}$ & $\mathrm{c}$ & $\mathrm{d}$ \\
\hline 64.8 & 48.4 & -86.1 & -78.5 \\
\hline 1.0 & 4.1 & 1.0 & 2.0 \\
\hline Coupling constants: & $\mathrm{J}_{\mathrm{ab}}=152 \mathrm{~Hz}, \mathrm{~J}_{\mathrm{ac}}=5.4 \mathrm{~Hz}$. \\
\hline
\end{tabular}


Table XXIV

NMR DATA FOR $\mathrm{F}^{\mathrm{a}}-\mathrm{SF}_{4}{ }^{\mathrm{b}}-\left(\mathrm{CF}_{2}{ }^{\mathrm{c}}-\mathrm{CF}^{\mathrm{d}} \mathrm{Br}\right)_{10}-\mathrm{Br}$

Chemical shifts (from $\mathrm{CFCl}_{3}$ ) and relative areas.

\begin{tabular}{|cccc|}
\hline$a$ & $b$ & $c$ & $d$ \\
\hline 65.1 & 46.0 & $\star$ & $\star$ \\
\hline 1.0 & 4.0 & $\star$ & $\star$ \\
\hline
\end{tabular}

* Broad peaks (with integration height) at 58.2 $(14), 71.0(11), 82.5$ (9), 86.2 (5), 93.0 (17), $100.9(70), 106.2(53), 129.5(52), 137.5(7)$.

Coupling constant: $J_{a b}=148 \mathrm{~Hz}$.

\section{MASS SPECTRUM}

The mass spectrum for $\mathrm{SF}_{5} \mathrm{CF}_{2} \mathrm{CFBr}_{2}$ is given in Table $\mathrm{XXV}$ below. Since this compound contains bromine, isotope peaks with similar intensity separated by 2 mass units are expected, and observed. If there are two bromine atoms present in a fragment, three peaks in a 1:2:1 ratio, separated by two mass units, are seen.

This compound also contains an $\mathrm{SF}_{5}-$ group, and the mass peaks characteristic of this group are all apparent in this spectrum. A molecular ion peak is observed at 367.9 , the calculated molecular weight is 367.88 . The base peak is not $\mathrm{SF}_{3}+$ as in the other $\mathrm{SF}_{5}$ - containing compounds, but $\mathrm{CF}_{2} \mathrm{CF}_{2} \mathrm{Br}+$ ion. This can be explained by a cyclic bromonium ion structure, which stabilizes this fragment. 
TABLE XXV

MASS SPECTRUM OF $\mathrm{SF}_{5} \mathrm{CF}_{2} \mathrm{CFBr}_{2}$

\begin{tabular}{|c|c|c|c|c|c|}
\hline $\mathrm{M} / \mathrm{e}$ & Rel. Int. & Type & $\mathrm{M} / \mathrm{e}$ & Rel.Int. & Type \\
\hline 43.0 & 0.3 & $\mathrm{C}_{2} \mathrm{~F}+$ & 142.9 & 2.5 & $\mathrm{C}_{2} \mathrm{~F}_{2} \mathrm{Br}+$ \\
\hline 44.0 & 2.0 & CS+ & 159.9 & 39.2 & $\mathrm{C}_{2} \mathrm{~F}_{3} \mathrm{Br}+$ \\
\hline 50.0 & 4.1 & $\mathrm{CF}_{2}+$ & 161.9 & 38.2 & $\mathrm{C}_{2} \mathrm{~F}_{3} \mathrm{Br}+$ \\
\hline 51.0 & 1.6 & $\mathrm{SF}+$ & 169.8 & 0.3 & $\mathrm{CBr}_{2}+$ \\
\hline 62.0 & 1.7 & $\mathrm{C}_{2} \mathrm{~F}_{2}+$ & 171.8 & 0.9 & $\mathrm{CBr}_{2}+$ \\
\hline 69.0 & 3.0 & $\mathrm{CF}_{3}+$ & 173.8 & 0.3 & $\mathrm{CBr}_{2}+$ \\
\hline 69.9 & 5.9 & $\mathrm{SF}_{2}+$ & 178.9 & 100.0 & $\mathrm{C}_{2} \mathrm{~F}_{4} \mathrm{Br}+$ \\
\hline 78.9 & 2.3 & Brt & 179.9 & 2.2 & ${ }^{13} \mathrm{C}_{2} \mathrm{~F}_{4} \mathrm{Br}+$ \\
\hline 80.9 & 2.4 & $\mathrm{Brt}$ & 180.9 & 98.6 & $\mathrm{C}_{2} \mathrm{E}_{4} \mathrm{Br}+$ \\
\hline 81.0 & 2.7 & $\mathrm{C}_{2} \mathrm{~F}_{3}+$ & 181.9 & 2.0 & ${ }^{13} \mathrm{C}_{2} \mathrm{~F}_{4} \mathrm{Br}+$ \\
\hline 89.0 & 33.1 & $\mathrm{SF}_{3}+$ & 188.8 & 17.7 & $\mathrm{CFBr}_{2}+$ \\
\hline 90.9 & 4.4 & $\mathrm{CBr}+$ & 190.8 & 33.5 & $\mathrm{CFBr}_{2}+$ \\
\hline 92.9 & 4.4 & $\mathrm{CBr}+$ & 192.8 & 16.3 & $\mathrm{CFBr}_{2}+$ \\
\hline 100.0 & 2.3 & $\mathrm{C}_{2} \mathrm{~F}_{4}+$ & 207.0 & 0.3 & $\mathrm{SE}_{5} \mathrm{C}_{2} \mathrm{~F}_{3}+$ \\
\hline 108.0 & 0.2 & $\mathrm{SE}_{4}+$ & 219.8 & 1.2 & $\mathrm{C}_{2} \mathrm{~F}_{2} \mathrm{Br}_{2}+$ \\
\hline 109.9 & 12.2 & CFBr+ & 221.8 & 2.5 & $\mathrm{C}_{2} \mathrm{~F}_{2} \mathrm{Br}_{2}+$ \\
\hline 111.9 & 12.3 & CFBrt & 223.8 & 1.2 & $\mathrm{C}_{2} \mathrm{~F}_{2} \mathrm{Br}_{2}+$ \\
\hline 121.9 & 0.8 & $\mathrm{C}_{2} \mathrm{FBr}+$ & 238.9 & 9.6 & $\mathrm{C}_{2} \mathrm{~F}_{3} \mathrm{Br}_{2}+$ \\
\hline 123.9 & 1.0 & $\mathrm{C}_{2} \mathrm{FBr}+$ & 240.9 & 18.6 & $\mathrm{C}_{2} \mathrm{~F}_{3} \mathrm{Br}_{2}+$ \\
\hline
\end{tabular}


TABLE XXV, cont.

\begin{tabular}{|lll|lll|}
\hline 127.0 & 18.6 & $\mathrm{SF}_{5}+$ & 242.9 & 9.4 & $\mathrm{C}_{2} \mathrm{~F}_{3} \mathrm{Br}_{2}+$ \\
\hline 128.9 & 23.8 & $\mathrm{CF}_{2} \mathrm{Br}+$ & 286.9 & 1.4 & $\mathrm{M}-\mathrm{Br}+$ \\
\hline 130.9 & 23.1 & $\mathrm{CF}_{2} \mathrm{Br}+$ & 288.9 & 1.4 & $\mathrm{M}-\mathrm{Br}+$ \\
\hline 140.9 & 2.7 & $\mathrm{C}_{2} \mathrm{~F}_{2} \mathrm{Br}+$ & 367.9 & 0.3 & $\mathrm{M}+$ \\
\hline
\end{tabular}


CHAPTER V

\section{CONCLUSION}

The reaction scheme used in this thesis has been shown to have general utility in the synthesis of $\mathrm{SF}_{5}$ - containing fluoroalkanesulfonic acids from fluoroolefins. The compounds $\mathrm{SF}_{5} \mathrm{CH}_{2} \mathrm{CH}_{2} \mathrm{SO}_{3} \mathrm{H}, \mathrm{SF}_{5} \mathrm{CH}_{2} \mathrm{CH}_{2} \mathrm{SO}_{3} \mathrm{Na}, \mathrm{SF}_{5} \mathrm{CH}_{2} \mathrm{CF}_{2} \mathrm{SO}_{3} \mathrm{H}$, $\mathrm{SF}_{5} \mathrm{CH}_{2} \mathrm{CF}_{2} \mathrm{SO}_{3} \mathrm{Na}$, $\mathrm{SF}_{5} \mathrm{CHFCF}_{2} \mathrm{SO}_{3} \mathrm{H}$ and $\mathrm{SF}_{5} \mathrm{CHFCF}_{2} \mathrm{SO}_{3} \mathrm{Na}$ have been prepared using this method, though the difluoro- acid and salt have not yet been completely purified. It has not yet proved possible to extend this reaction scheme to perfluorinated systems, but there is spectroscopic and other evidence that the acids are being formed for this and the vinyl fluoride. The possibility of a competing carbene mechanism in the sulfite addition can give rise to a mixture of products, but these are usually separated by conversion to the acid and sublimation.

Preliminary studies into the utility of this reaction scheme for other mono- and di- brominated systems have been initiated, though there is much more to be done in this area. The $\mathrm{SF}_{5} \mathrm{Br}$ addition to olefins can provide a wide variety of starting materials for these reactions, and this reaction was used to prepare the new compounds $\mathrm{SF}_{5} \mathrm{CF}_{2} \mathrm{CFBr}_{2}$ and $\mathrm{SF}_{5}\left(\mathrm{CF}_{2} \mathrm{CFBr}\right)_{10} \mathrm{Br}$. 


\section{REFERENCES}

1 Wolf Vielstich, Euel Cells, Wiley-Interscience, London. 1970 .

${ }^{2}$ S.W. Angrist, Direct Energy Conversion, Allyn and Bacon Inc., Boston. 1982 .

${ }^{3}$ K.R. Williams, An Introduction to Fuel Cells, Elsevier Pub. Co., Amsterdam, 1966.

$4 \mathrm{~J}$. Ahmad et al., Electrochem. Sci. and Tech., 128, 2257 (1981).

${ }^{5}$ L.G. Austin, H.W. Pickering, B.G. Ateyeh, N. Rebert, and T. Poweigha, U.S. Dept. of Energy Contract \#COO-2927-1.

${ }^{6}$ M.W. Breiter, Electrochim. Acta, 8, 925 (1963).

${ }^{7}$ L.G. Austin, et al., op. cit.

${ }^{8} \mathrm{~J}$. Bockris and S. Srinivasan, Euel Cells: Their

Electrochemistry, McGraw-Hill Book Co., New York, 1969.

${ }^{9}$ S.S. Penner, U.S. Dept. of Energy contract \#DE86 002003.

$10 \mathrm{~J}$. Ahmad, et al., op. cit.

11 S.B. Brummer, J. Foos, J. McHardy, J. McVeigh, D. Toland, and M. Turner, U.S. Dept. of Energy Contract \#EY-76-C03-1363.

12 G.W. Walker and R.T. Foley, J. Electrochem. Soc. 128, 1502 (1981).

${ }^{13}$ A.J. Appleby and B.S. Baker, J. Electrochem. Soc. 125, 404 (1978).

${ }^{14} \mathrm{~K}-\mathrm{L}$. Hsueh, E.R. Gonzalez, and S. Srinivasan, Electrochimica Acta 28, 691 (1983).

${ }^{15}$ R.D. Howells and J.D. McCowan, Chem. Rev. 77, 69 (1977). 
${ }^{16} \mathrm{G} . \mathrm{W}$. Walker and R.T. Foley, op. cit.

17 S.B. Brummer, et al., op. cit.

${ }^{18}$ P.N. Ross, Jr., J. Electrochem. Soc., 130, 882 (1983).

${ }^{19}$ B. Cohen and A.G. MacDiarmid, Inorg. Chem. 4, 1782 (1965).

${ }^{20}$ S.B. Brummer, et al., ep. cit.

$21 \mathrm{~J}$. Steward, L. Kegley, H.F. White, and G.L. Gard, J. Org. Chem. 34, 760 (1969).

${ }^{22}$ R.S. Terjeson, G.I.Gard, J. Fluorine Chem., to be published.

$23 \mathrm{~J}$. Hutchison, J. Fluorine Chem. 3, 429 (1973).

${ }^{24} \mathrm{C}$. Bunyugidj, H. Piotrowska, and M.H. Aldridge, J. Chem. Eng. Data 26, 344 (1981).

${ }^{25}$ C. Bunyugidj, H. Piotrowska, and M.H. Aldridge, J. Org. Chem. 46, 3335 (1981).

${ }^{26}$ G.G.I. Moore, J. Org. Chem. 44, 1708 (1979).

${ }^{27}$ M.E. Lerchen and G.I. Gard, Portland State U., private communication.

${ }^{28}$ G.G.I. Moore, op. eit.

${ }^{29} \mathrm{~S}$. Anderson, E. Constable, K. Seddon, J. Turp, J. Baggett and M. Pilling, J. Chem. Soc. Dalt. Trans. 1985, 2247.

${ }^{30} \mathrm{~A}$. Streitweiser and C.H. Heathcock, Intreduction to Organic Chemistry, Macmillan Pub. Co., New York, 1985. p.766.

${ }^{31}$ C. Wakselman and C. Kaziz, J. Fluorine Chem. 33, 347 (1986).

32 I. Rico, D. Cantacuzene, and C. Wakselman, J. Chem. Soc. Perkin I, 1982, 1063.

${ }^{33}$ G.G.I. Moore, op. cit.

${ }^{34} \mathrm{H}$. Wei-Yuan, H. Bing-nan, and H. Chang-ming, J. Fluorine Chem. 23, 193 (1983). 
35. Thanks to R. Terjeson, Portland State U., for making the iodide for this reaction.

${ }^{36}$ G.I. Gard and C. Woolf, J. Fluorine Chem. 1, $492(1971 / 2)$.

37 J.K. Brown and K.J. Morgan, Adv. Fluorine Chem. 4, 253 (1965).

${ }^{38}$ R.A. DeMarco and W.B. Fox, J. Fluorine Chem. 12, 137 (1978).

39 J.W. Emsley and L. Phillips, Progress in NMR Spectroscopy 7, 1 (1971).

${ }^{40}$ H.F. White, Anal. Chem. 36, 1291 (1964).

${ }^{41}$ R.A. Hoffman, S. Forsen, and B. Gestblom, Nuclear Magnetic Resonance 5, 1 (1971).

42 P.M. Nair and J.D. Roberts J. Am. Chem. Soc. 79, 4564 (1957).

43 J.W. Emsley, I. Phillips, and V. Wray, Progress in NMR Spectroscopy 10, 83 (1977).

44 This is the symbol used for a viscinal ( 3 bond) H-F coupling constant.

${ }^{45}$ M. Barber, Ana1. Chem. 54, 645 A (1982).

${ }^{46}$ K.G. Furton and C.F. Poole, Org. Mass. Spec. 22, 210 (1987).

47 C. Larsen, U. Anthoni, P.H. Nelson, and C. Christopherson, Org. Mass Spec. 22, 117 (1987).

${ }^{48}$ E. Schroder, H. Minster, and H. Budzikiewicz, Org. Mass Spec. 21, 707 (1986).

${ }^{49}$ R.J. Koshar and R.A. Mitsch, J. Org. Chem. 38, 3358 (1973).

50 J.E.H. Hancock, Reed College, personal communication.

${ }^{51}$ C. Bunyugidj, et al. J. Chem. Eng. Data 26, 344 (1981). 


\section{APPENDIX}

INFRARED SPECTRA

PAGE

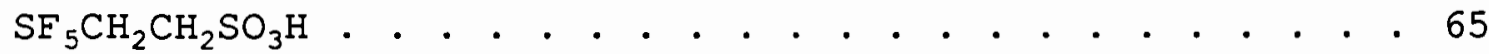

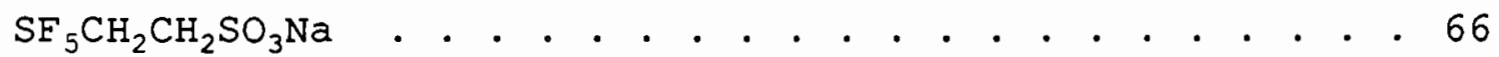

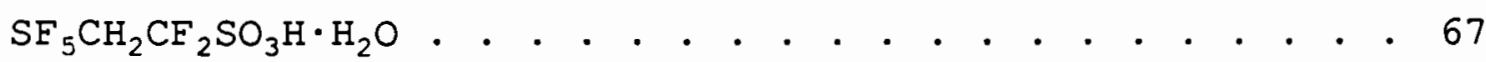

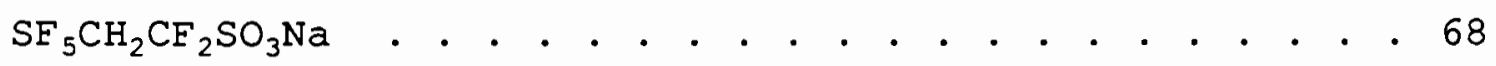

$\mathrm{SF}_{5} \mathrm{CHFCF}_{2} \mathrm{SO}_{3} \mathrm{H} \cdot \mathrm{H}_{2} \mathrm{O}$.

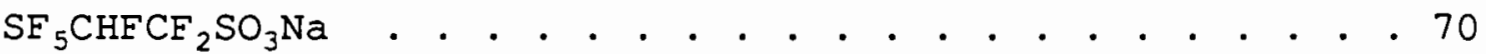

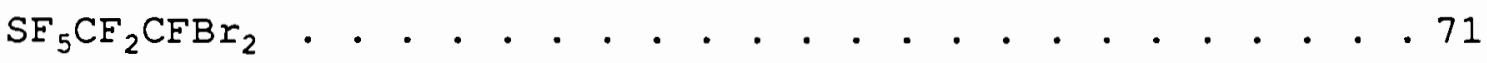

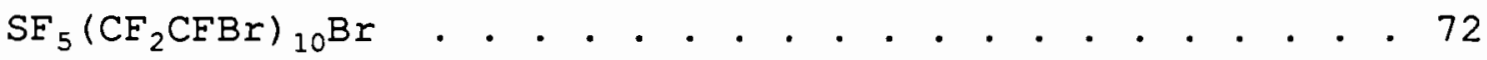

NMR SPECTRA

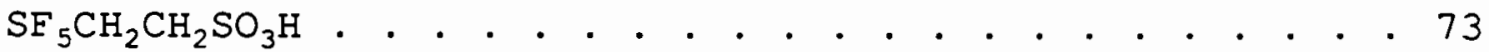

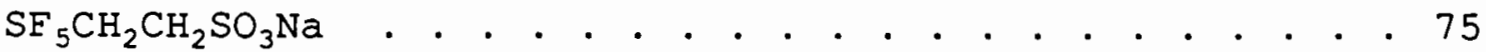

$\mathrm{SF}_{5} \mathrm{CH}_{2} \mathrm{CF}_{2} \mathrm{SO}_{3} \mathrm{H} \cdot \mathrm{H}_{2} \mathrm{O}$..$\quad$. . . . . . . . . . . . . . . . 77

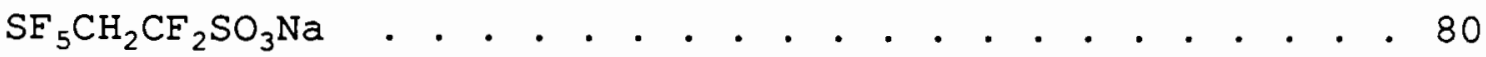

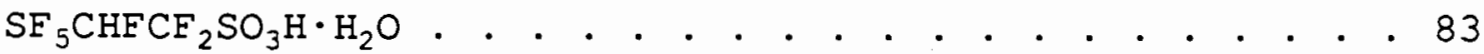

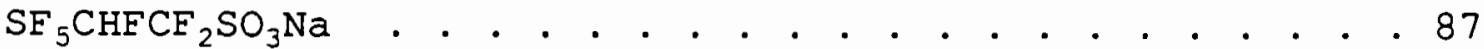

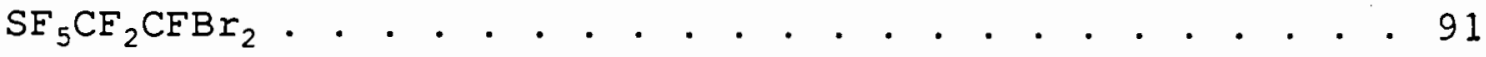

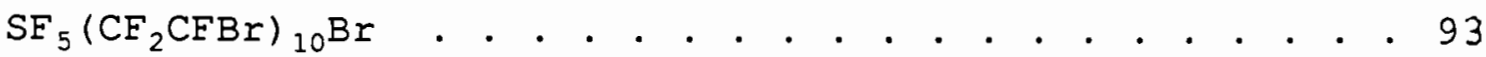




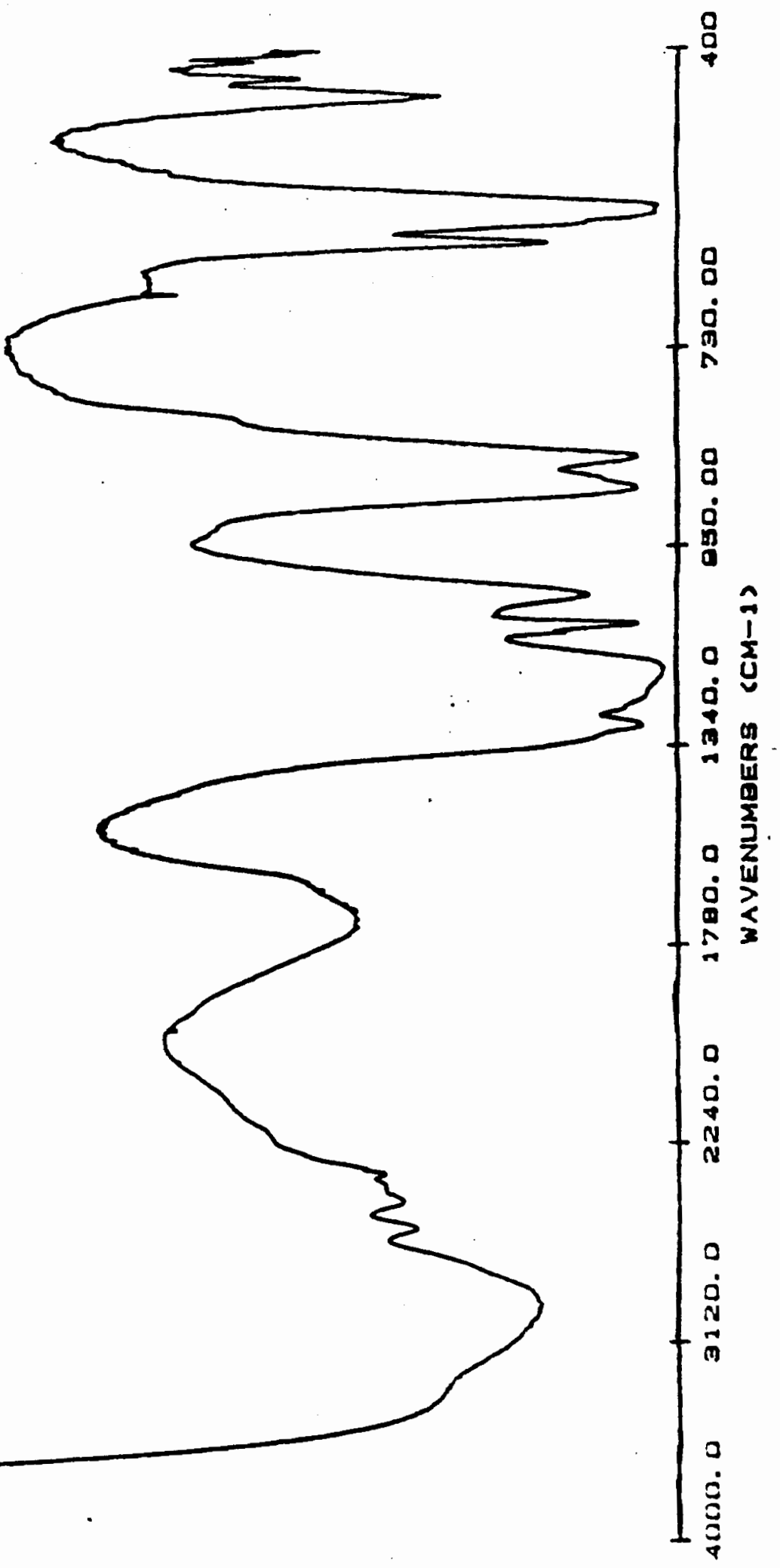




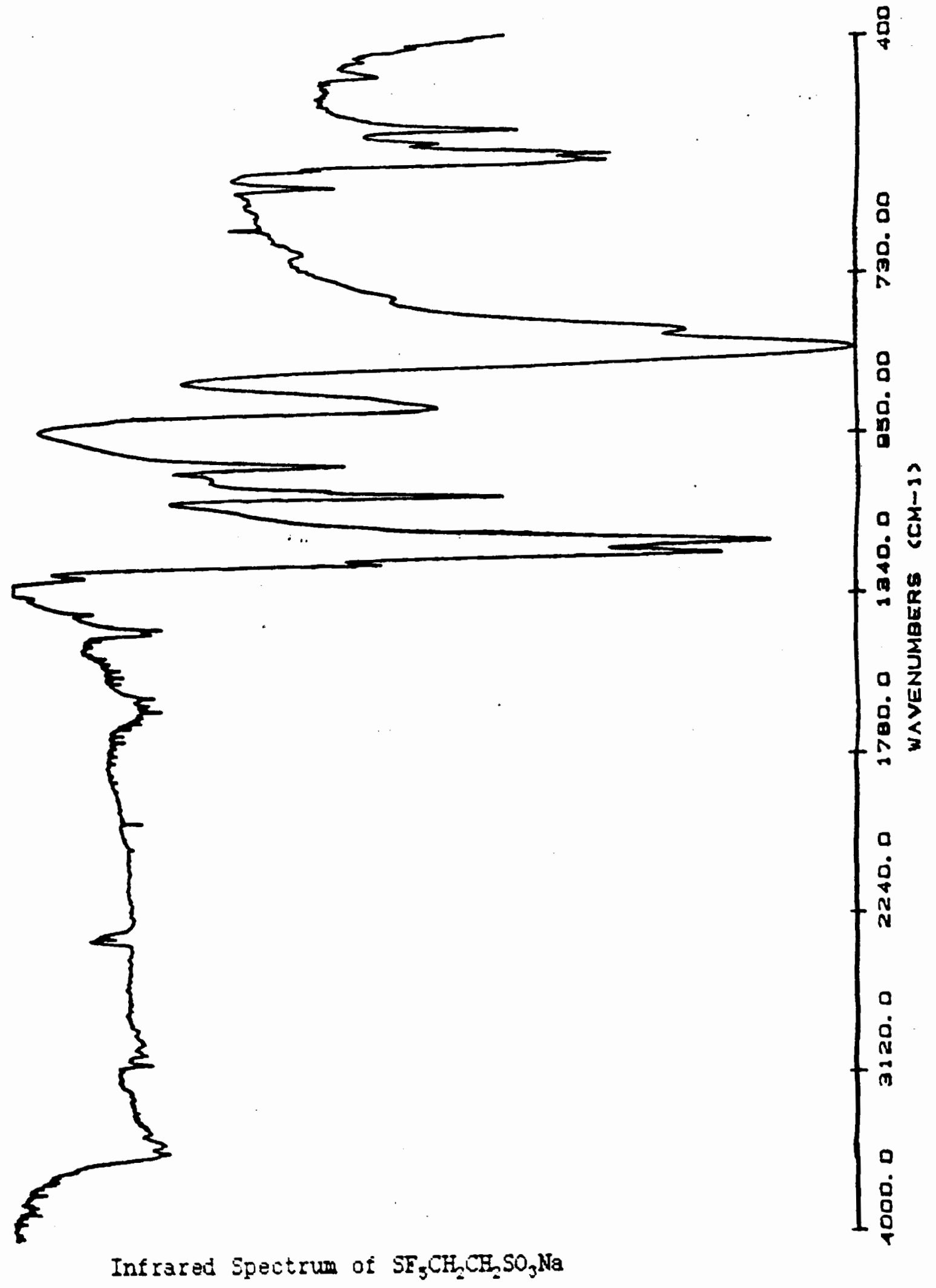




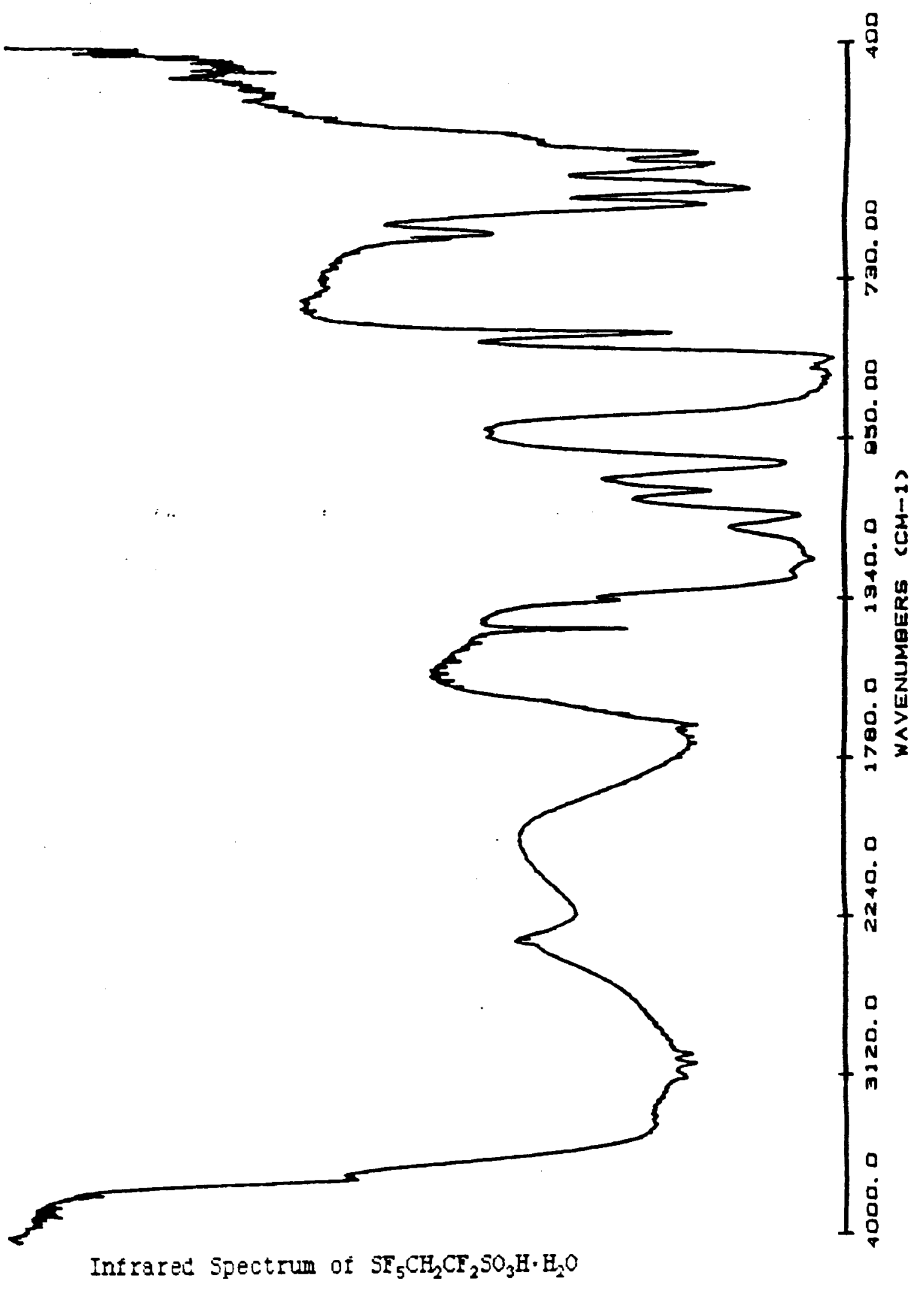




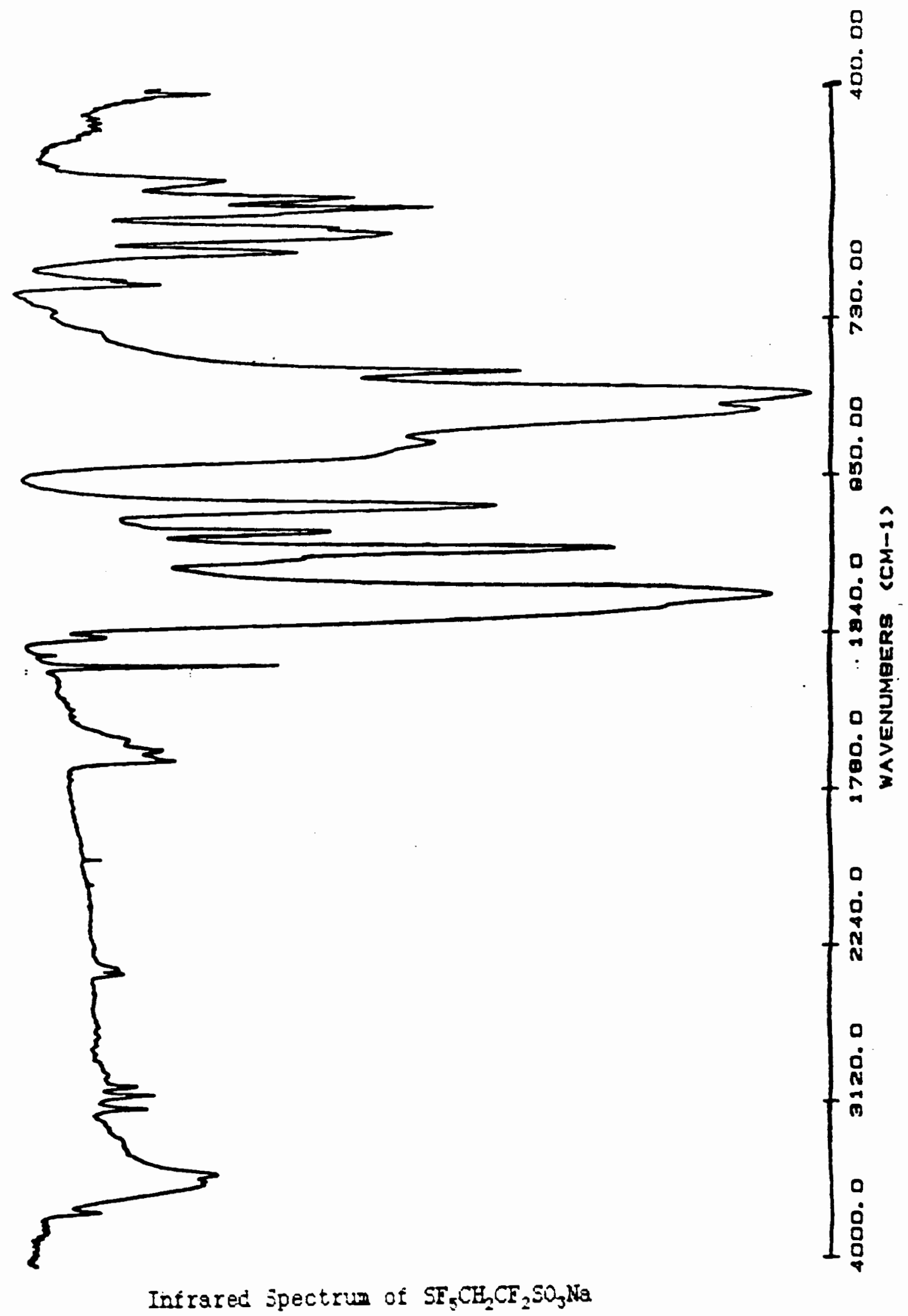




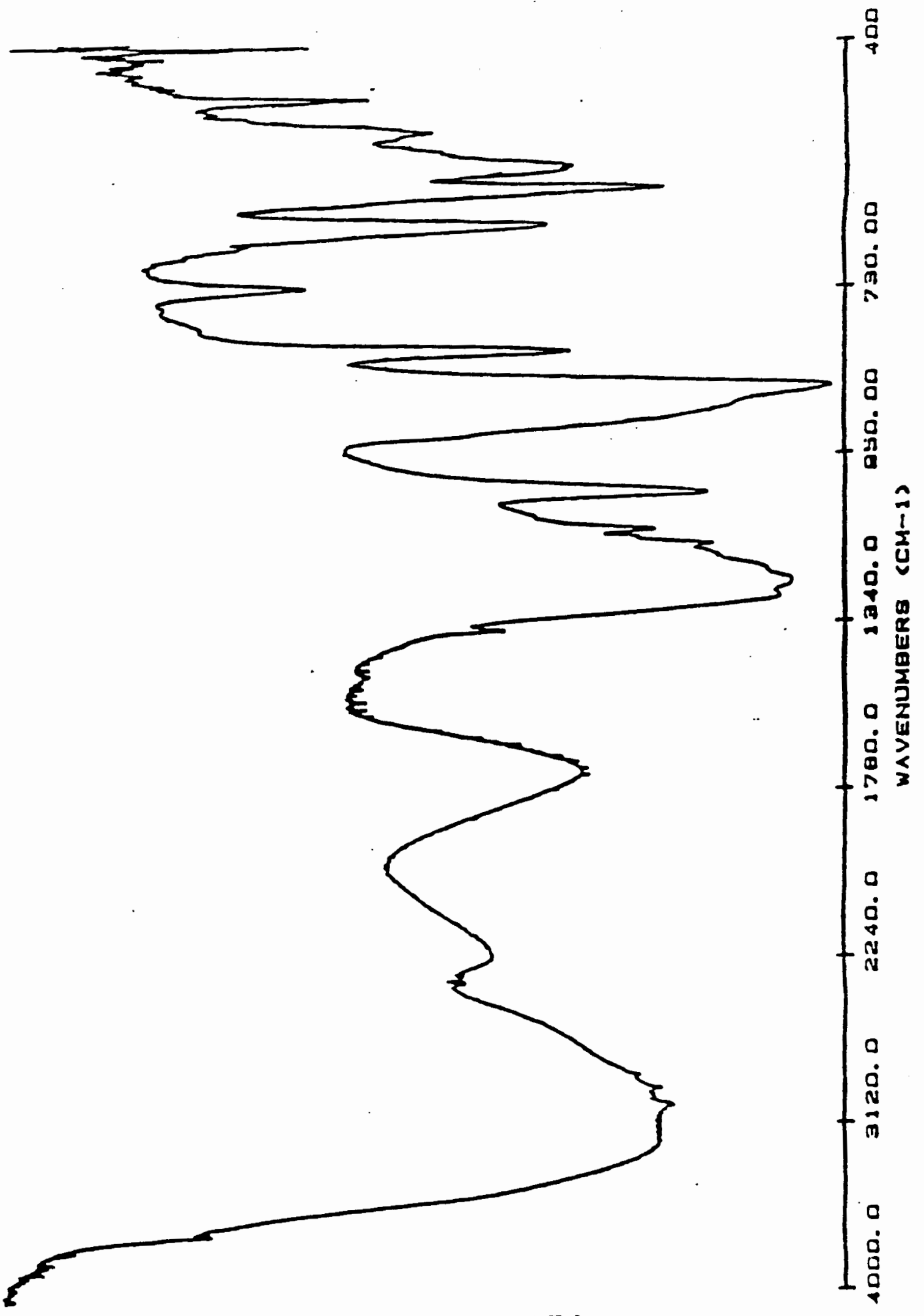

intrered Spectram of $\mathrm{SF}_{5} \mathrm{CHTCF}_{2} \mathrm{SO}_{3} \mathrm{E} \cdot \mathrm{H}_{2} \mathrm{O}$ 


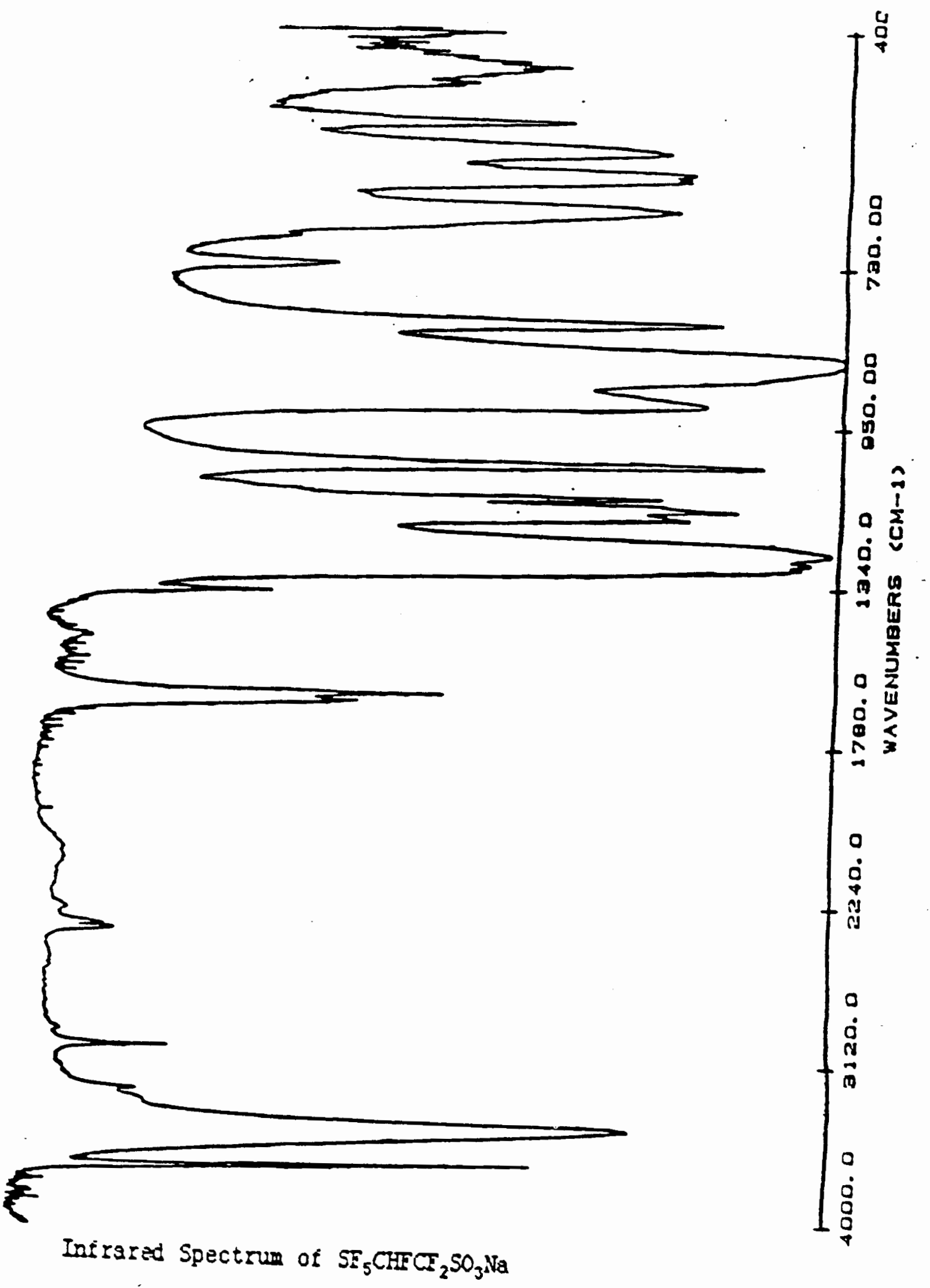



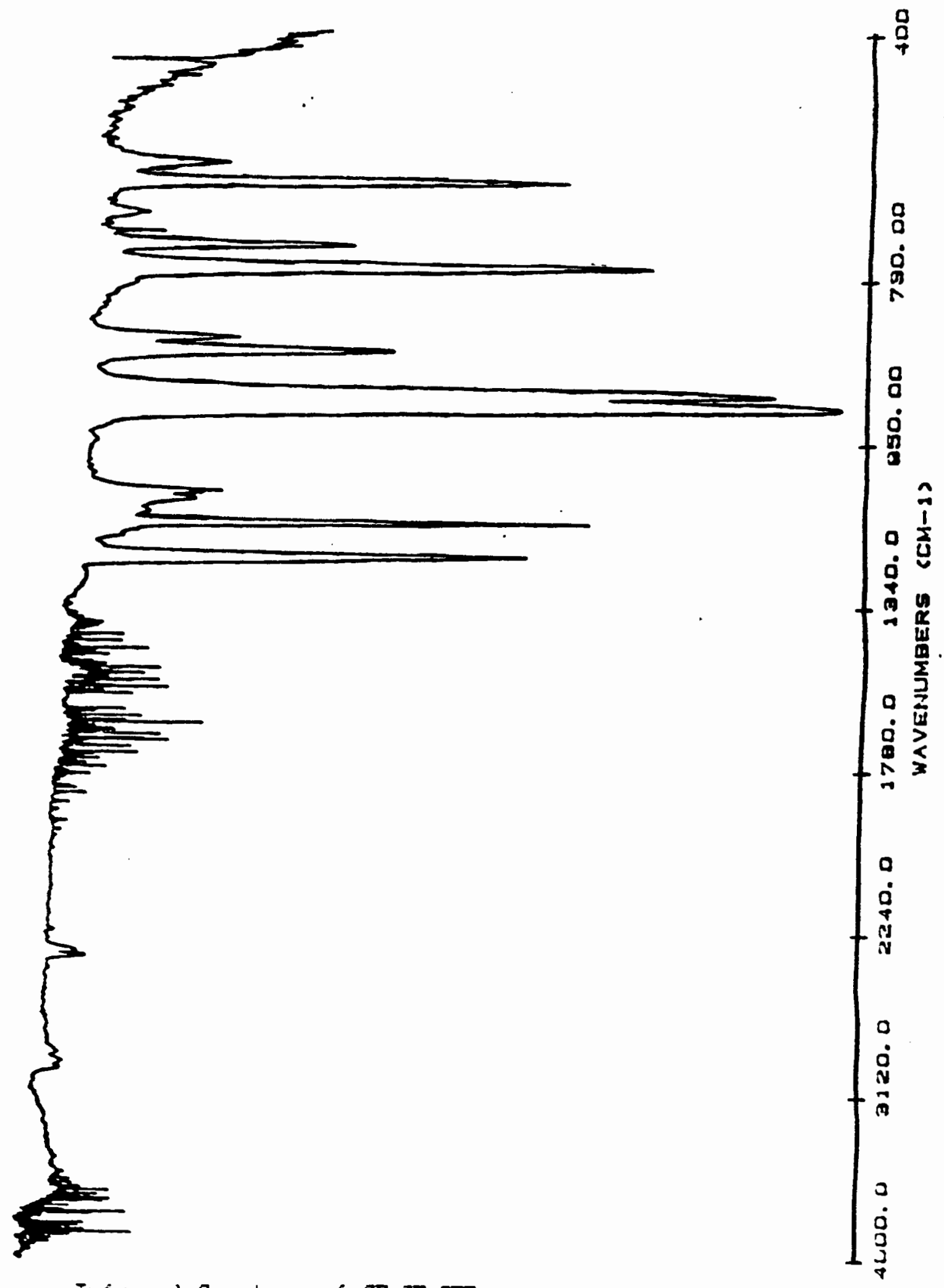

Inf rared Spectrum of $\mathrm{SF}_{5} \mathrm{CF}_{2} \mathrm{CrBr}_{2}$ 

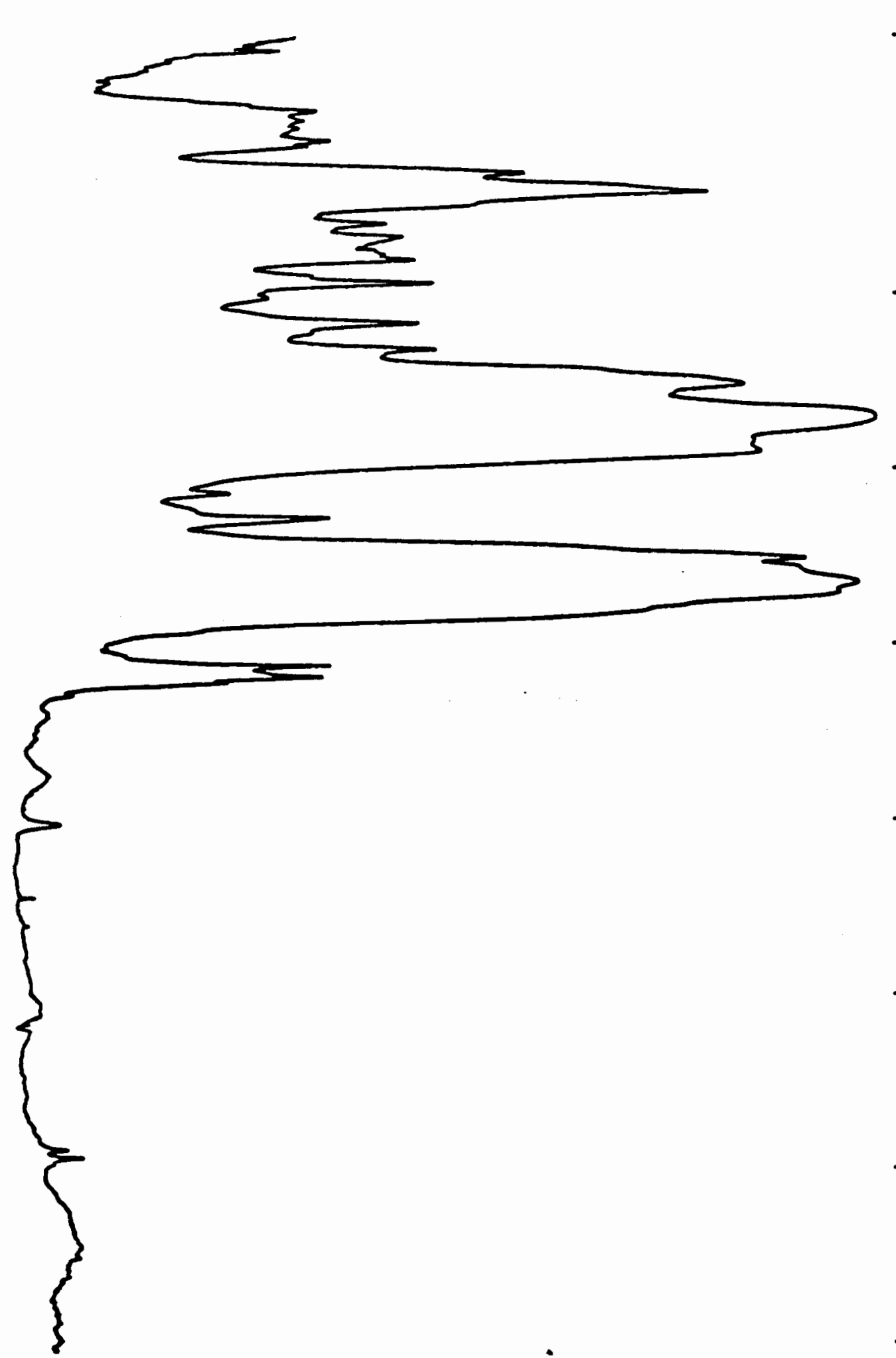


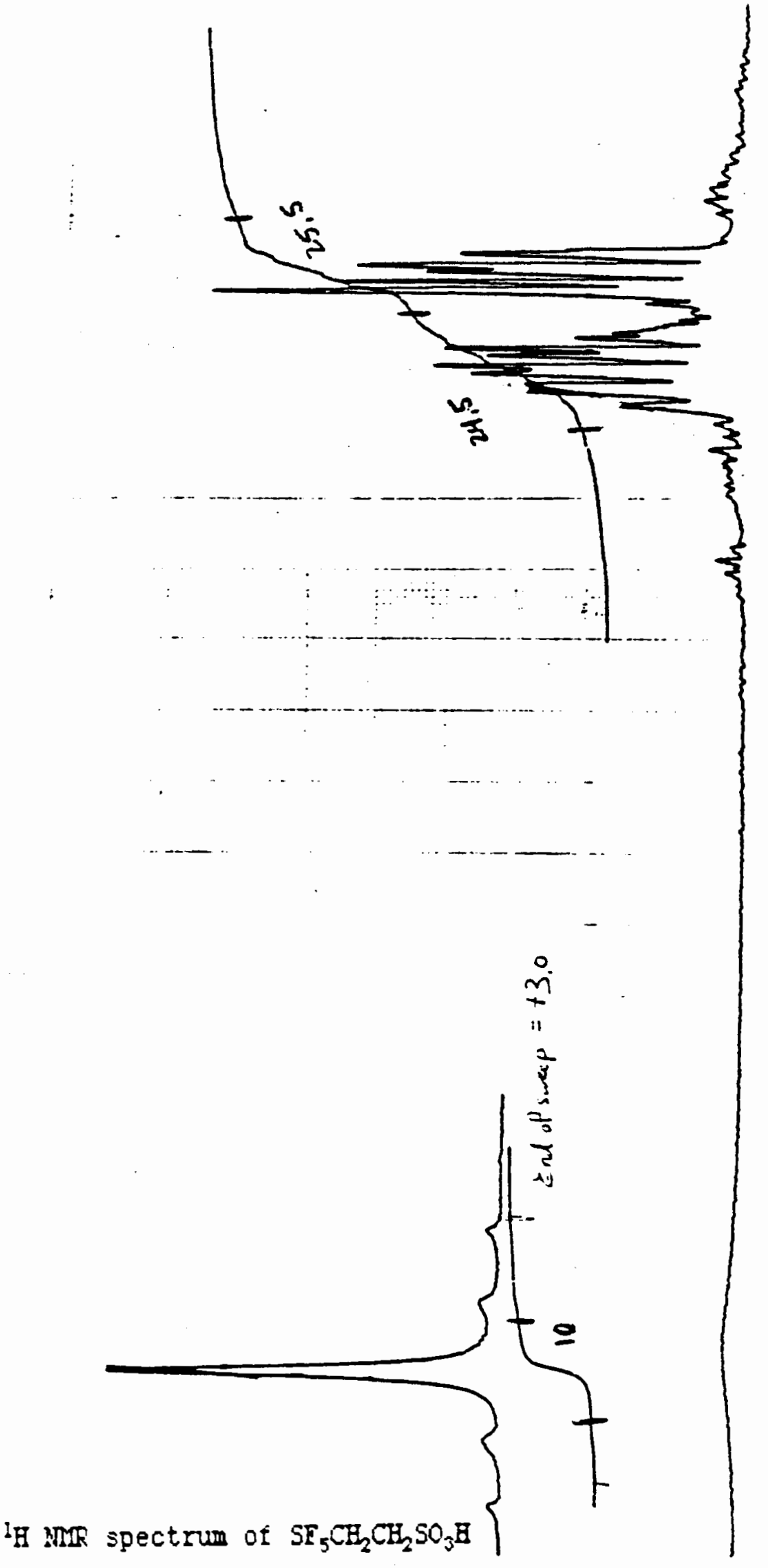




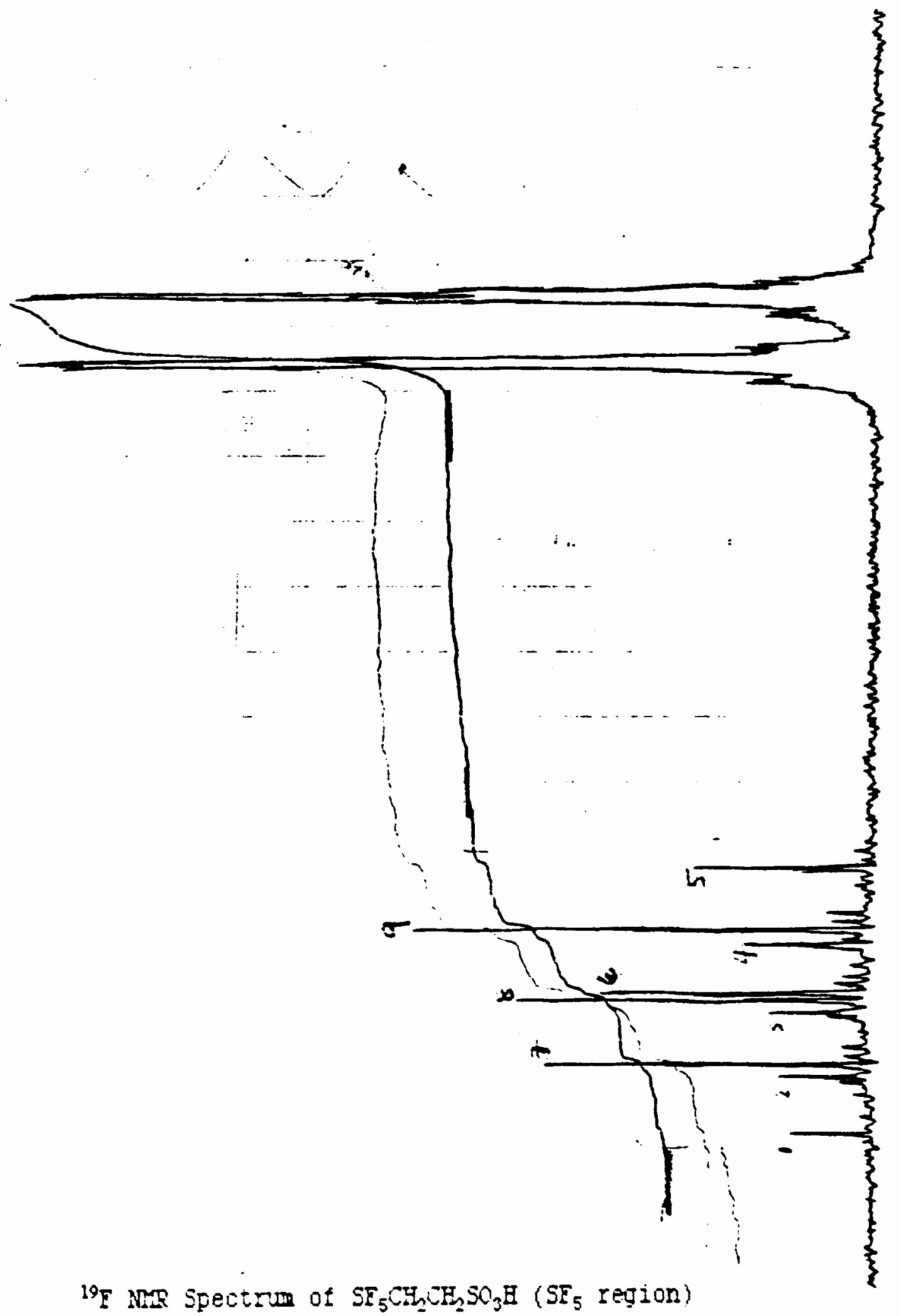




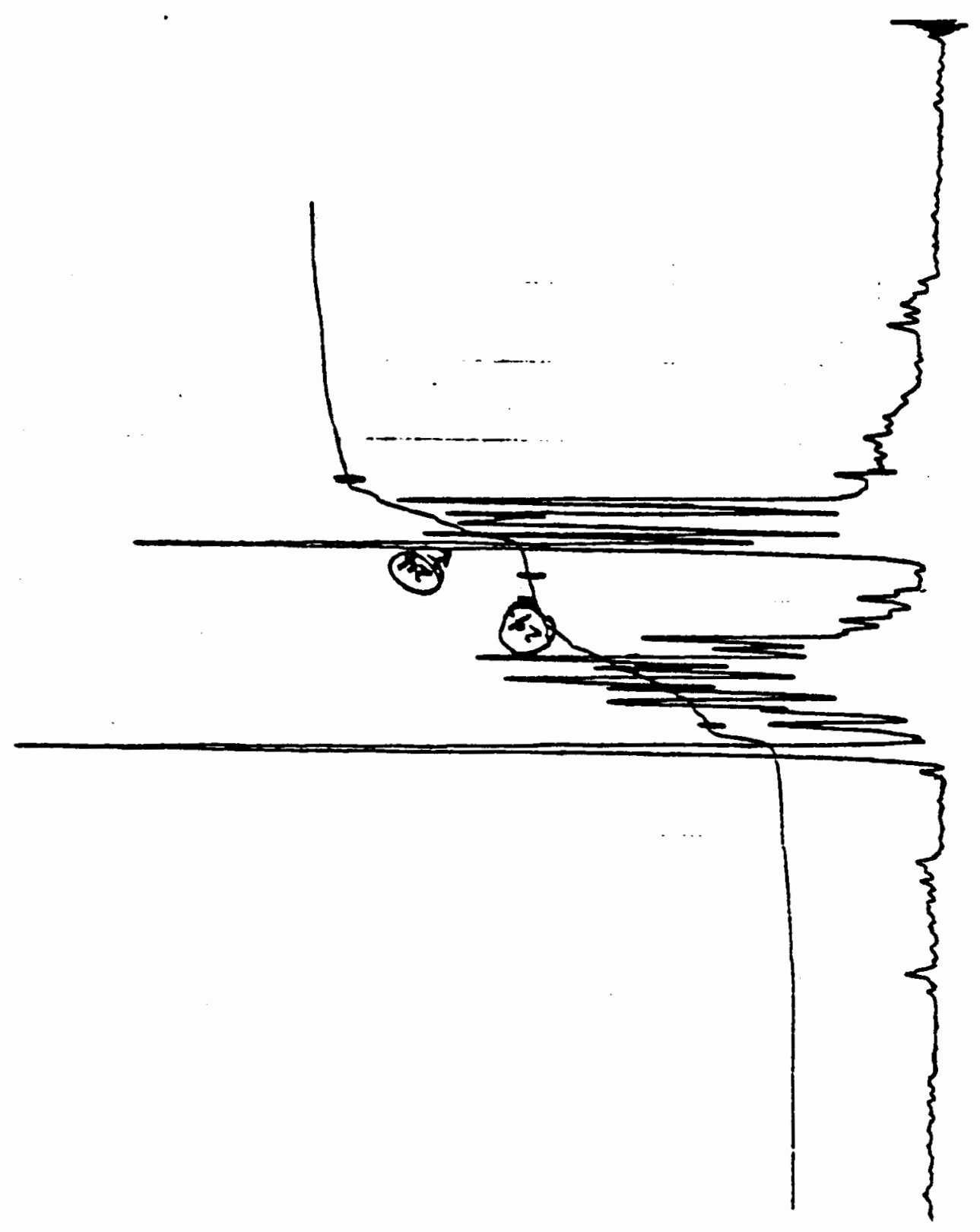

${ }^{1} \mathrm{H} \operatorname{ing}$ spectrum of $\mathrm{SF}_{5} \mathrm{CH}_{2} \mathrm{CH}_{2} \mathrm{SO}_{3} \mathrm{Na}$ 


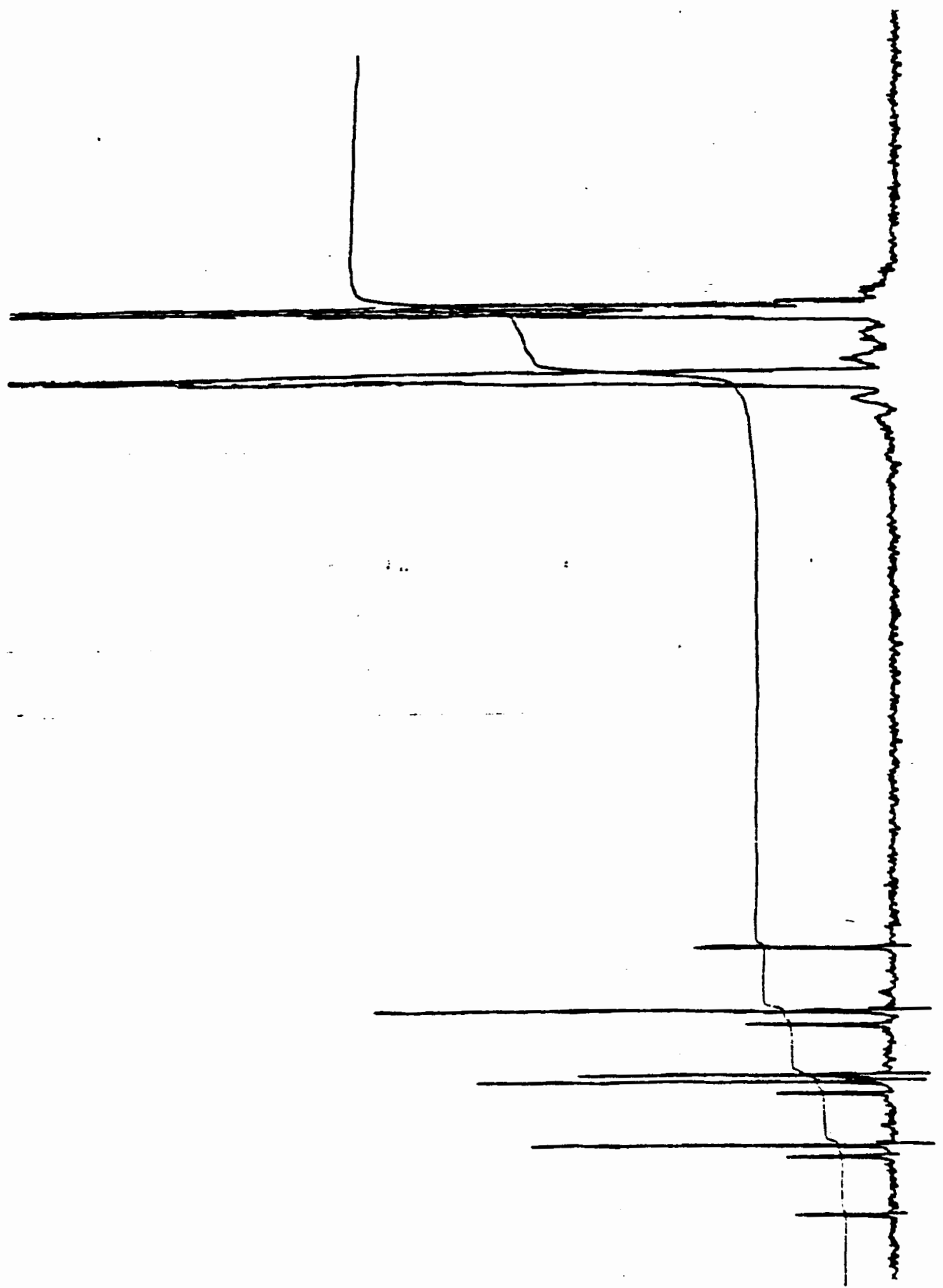

${ }^{19} \mathrm{~F}$ NRF Specisum of $\mathrm{SF}_{5} \mathrm{CH}_{2} \mathrm{CE}_{2} \mathrm{SO}_{3} \mathrm{Na}$ (SF $\mathrm{Segion}$ ) 


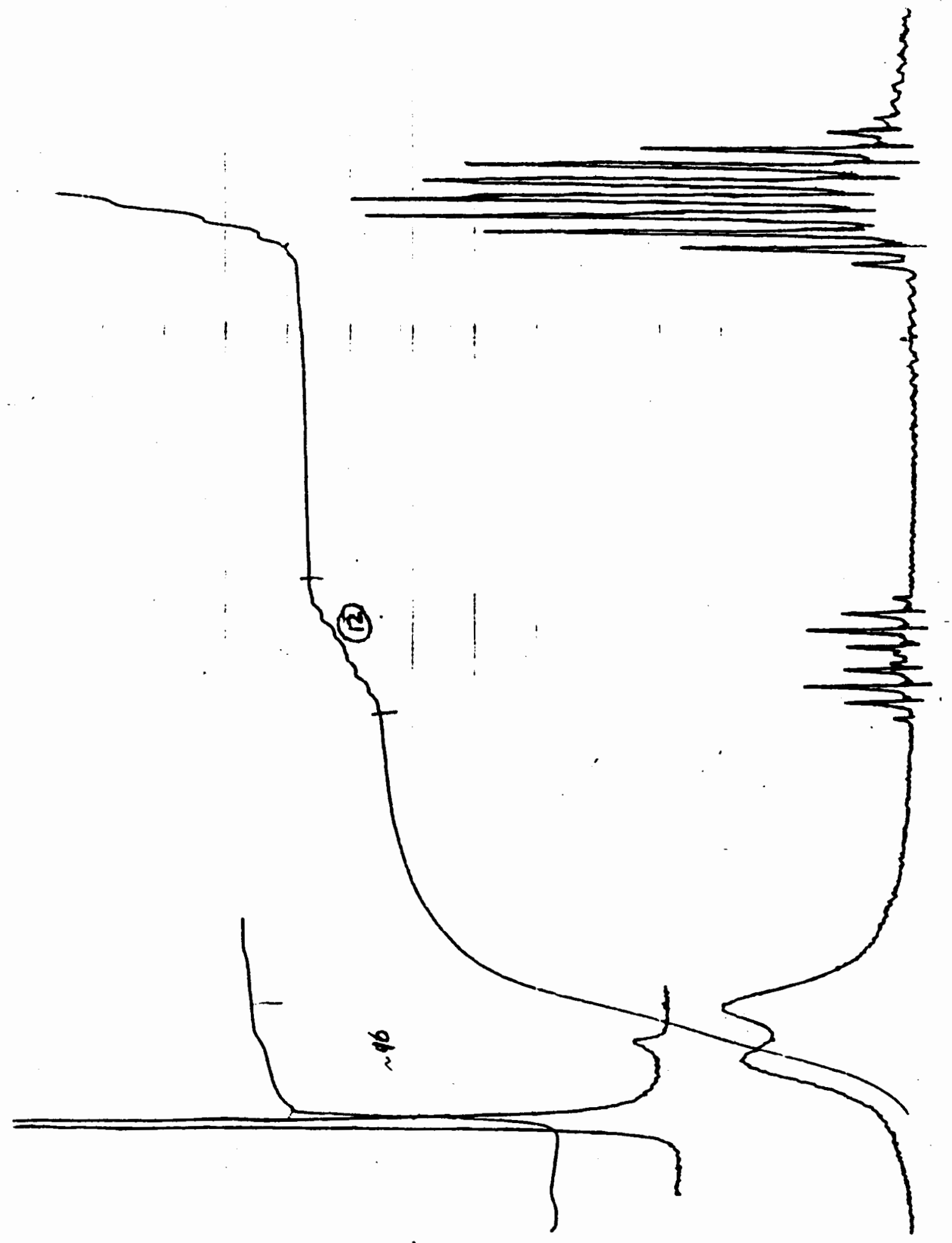

la MTR spectrum of $\mathrm{SF}_{\mathrm{S}} \mathrm{H}_{2} \mathrm{CF}_{2} \mathrm{SO}_{\mathrm{s}} \mathrm{Z} \cdot \mathrm{H}_{2} \mathrm{O}$ 


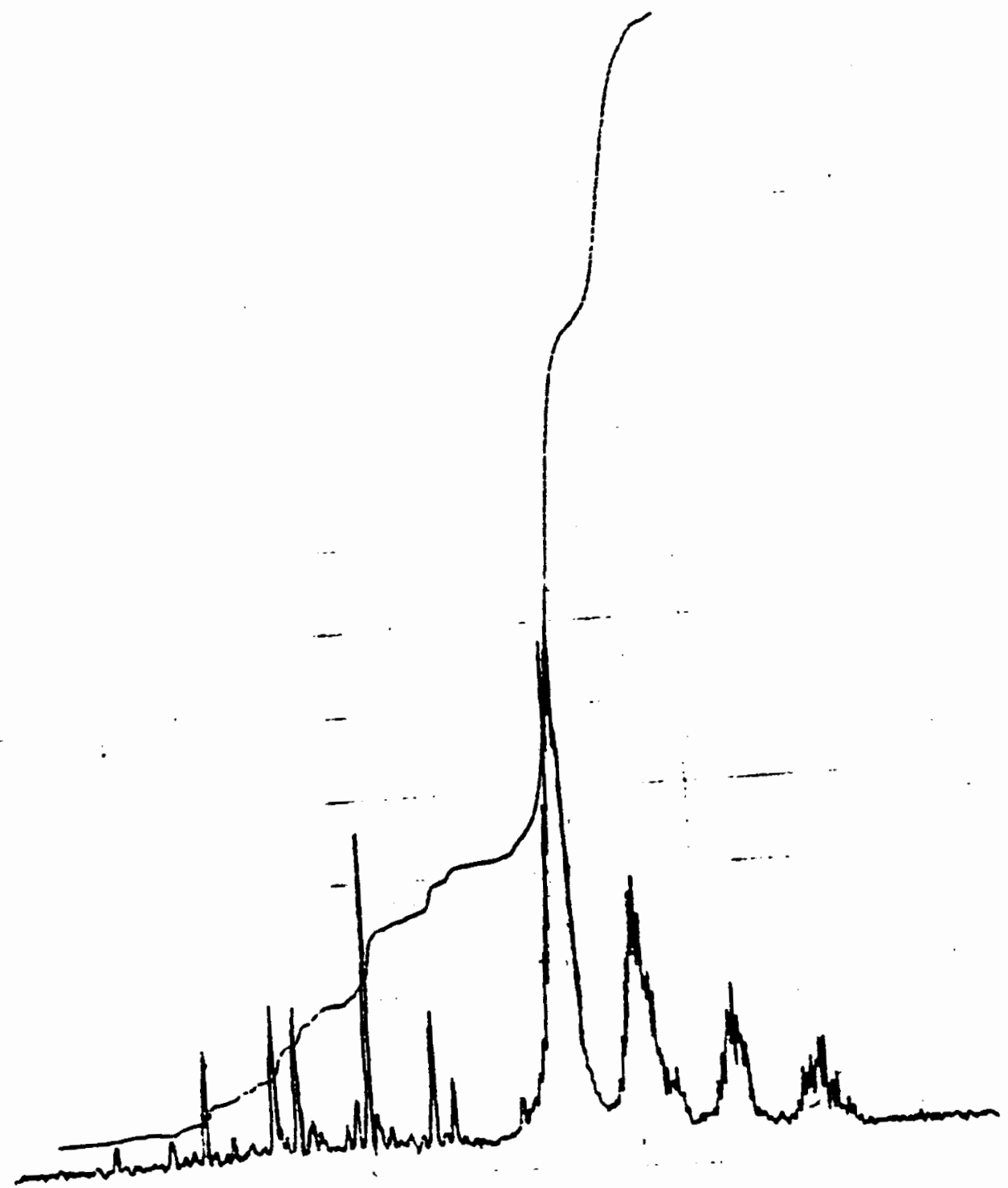

1PE UTR Spectrum of $5 F_{5} \mathrm{CH}_{2} \mathrm{~F}_{2} \mathrm{SO} \mathrm{H} \cdot \mathrm{E}_{2} \mathrm{O}$ ( $\mathrm{SF}_{5}$ region) 


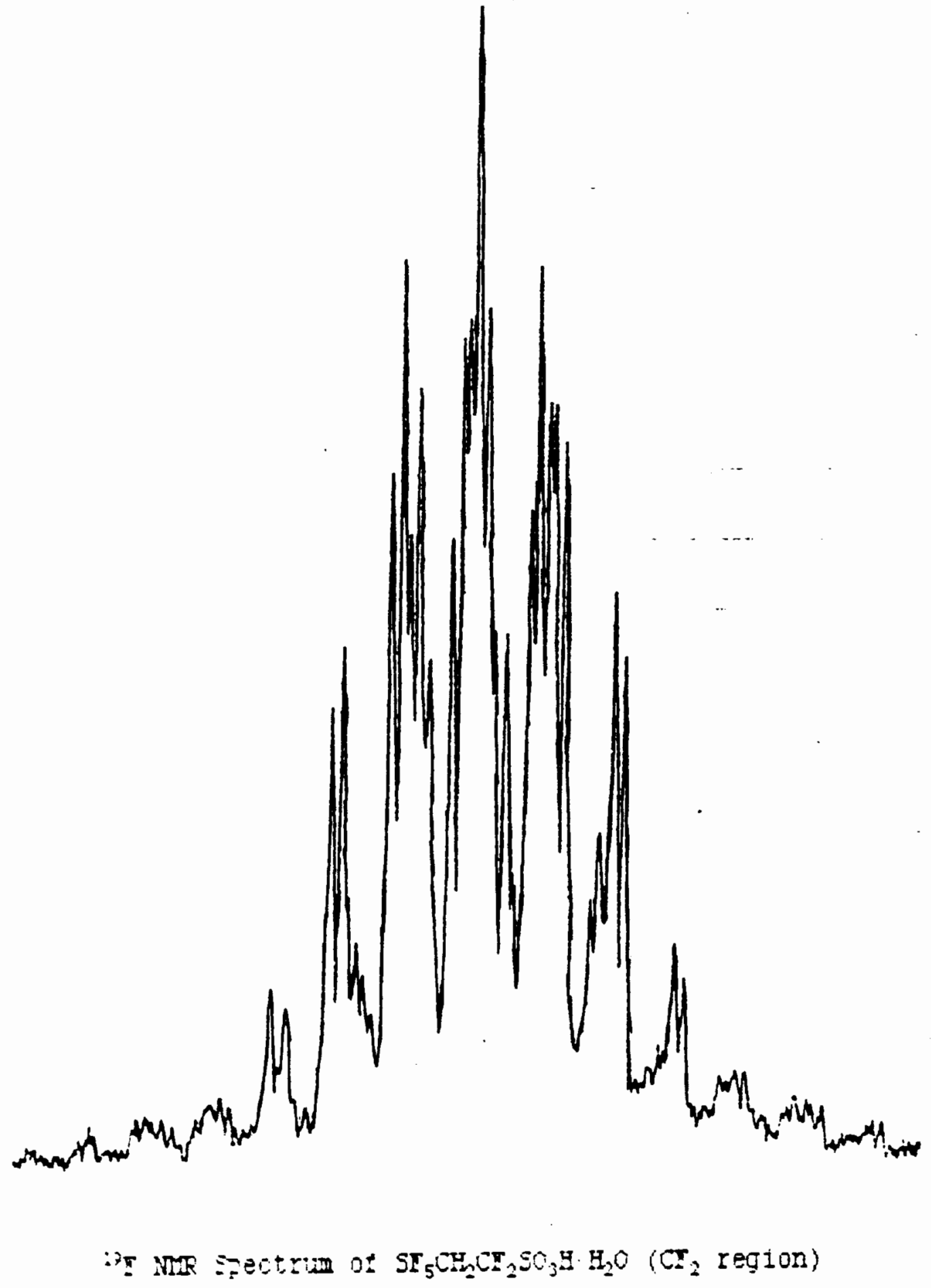


80

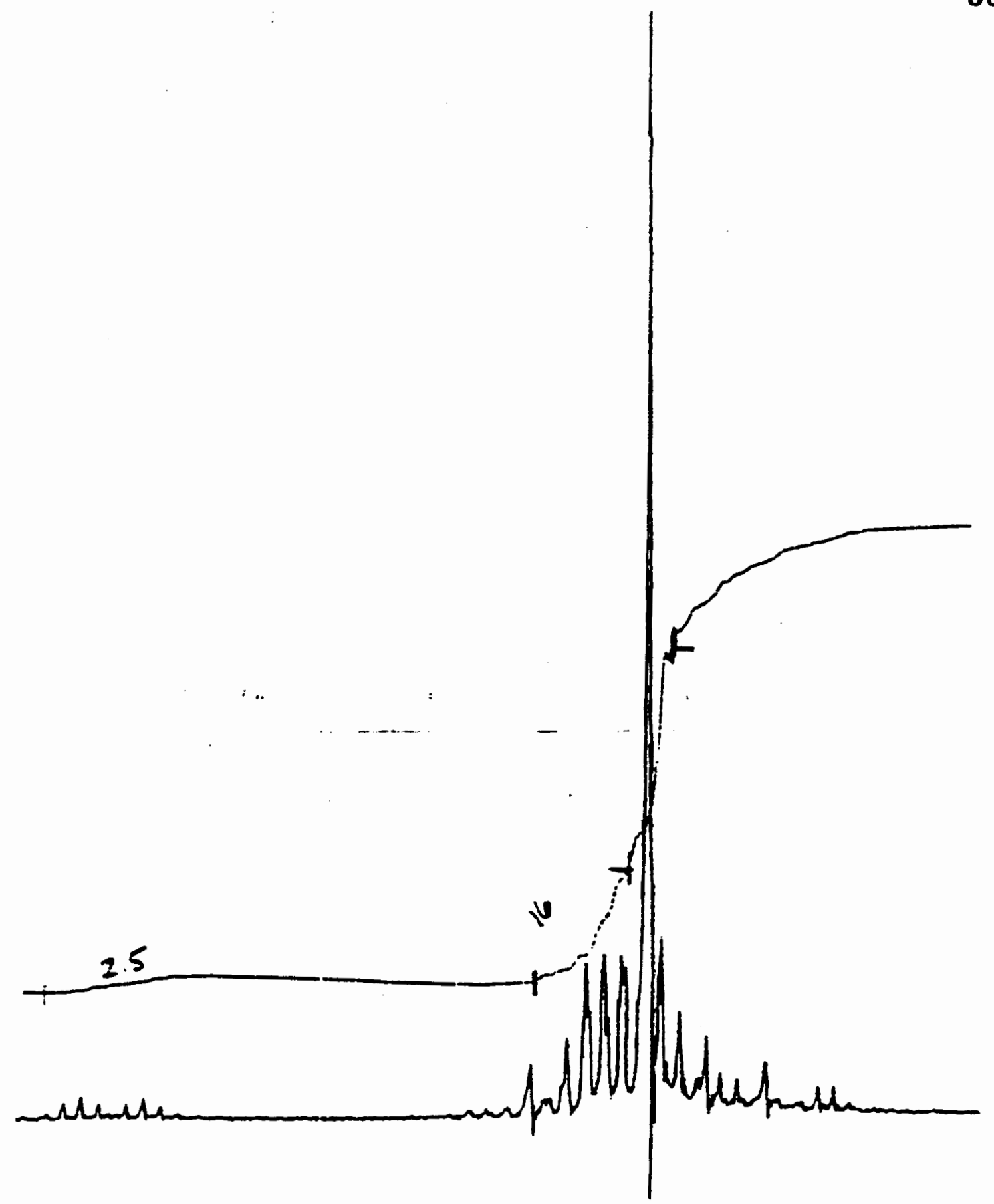

it NMR spectrum of $5 \mathrm{~F}_{5} \mathrm{CH}_{2} \mathrm{CF}_{2} \mathrm{SO}_{3} \mathrm{Na}$ 


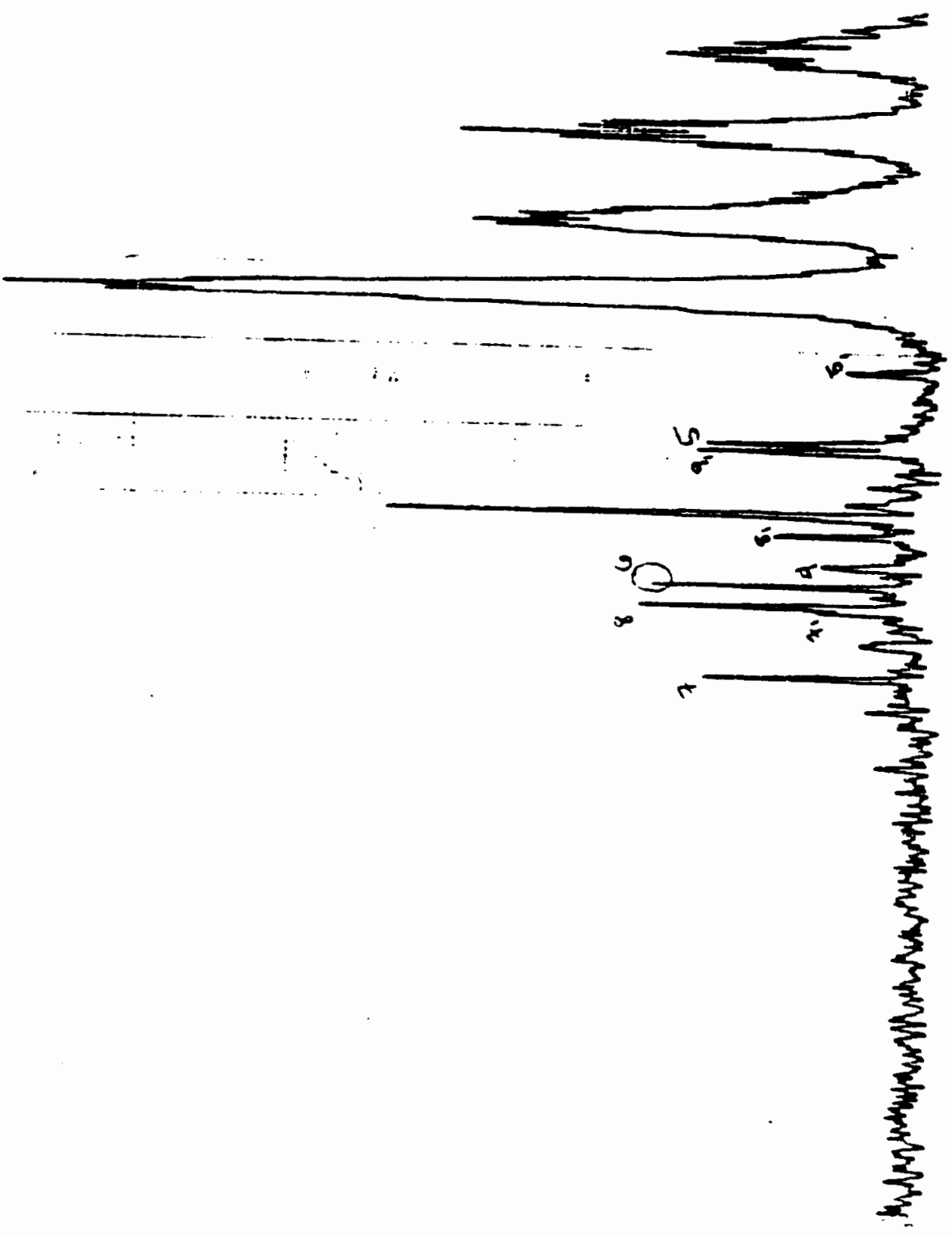

:PF MTR Epectrum of $\mathrm{SF}_{5} \mathrm{CH}_{2} \mathrm{CF}_{2} \mathrm{SO}_{3} \mathrm{il}$ (SF region\} 


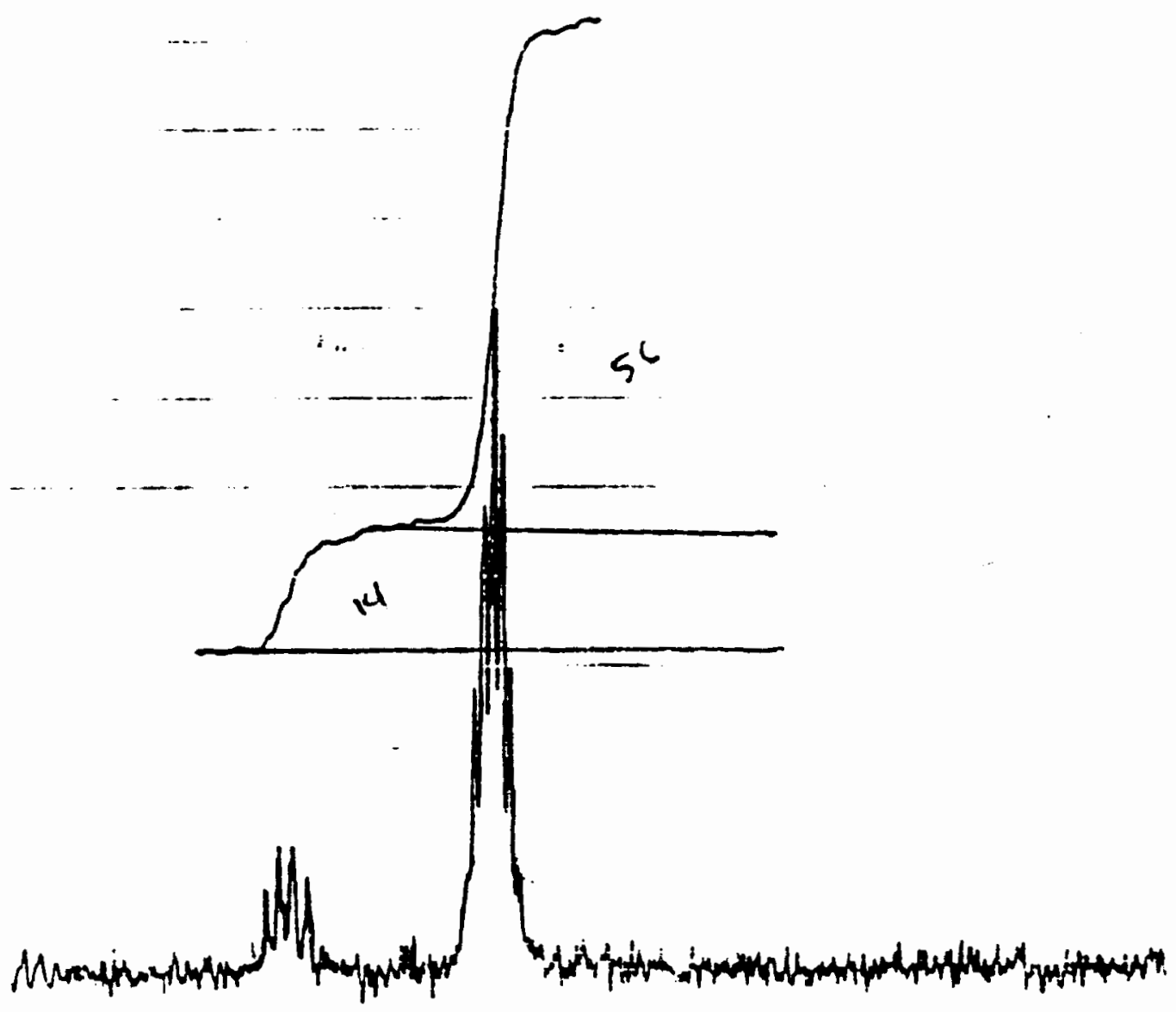

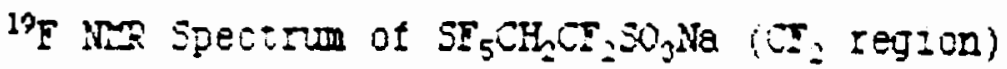




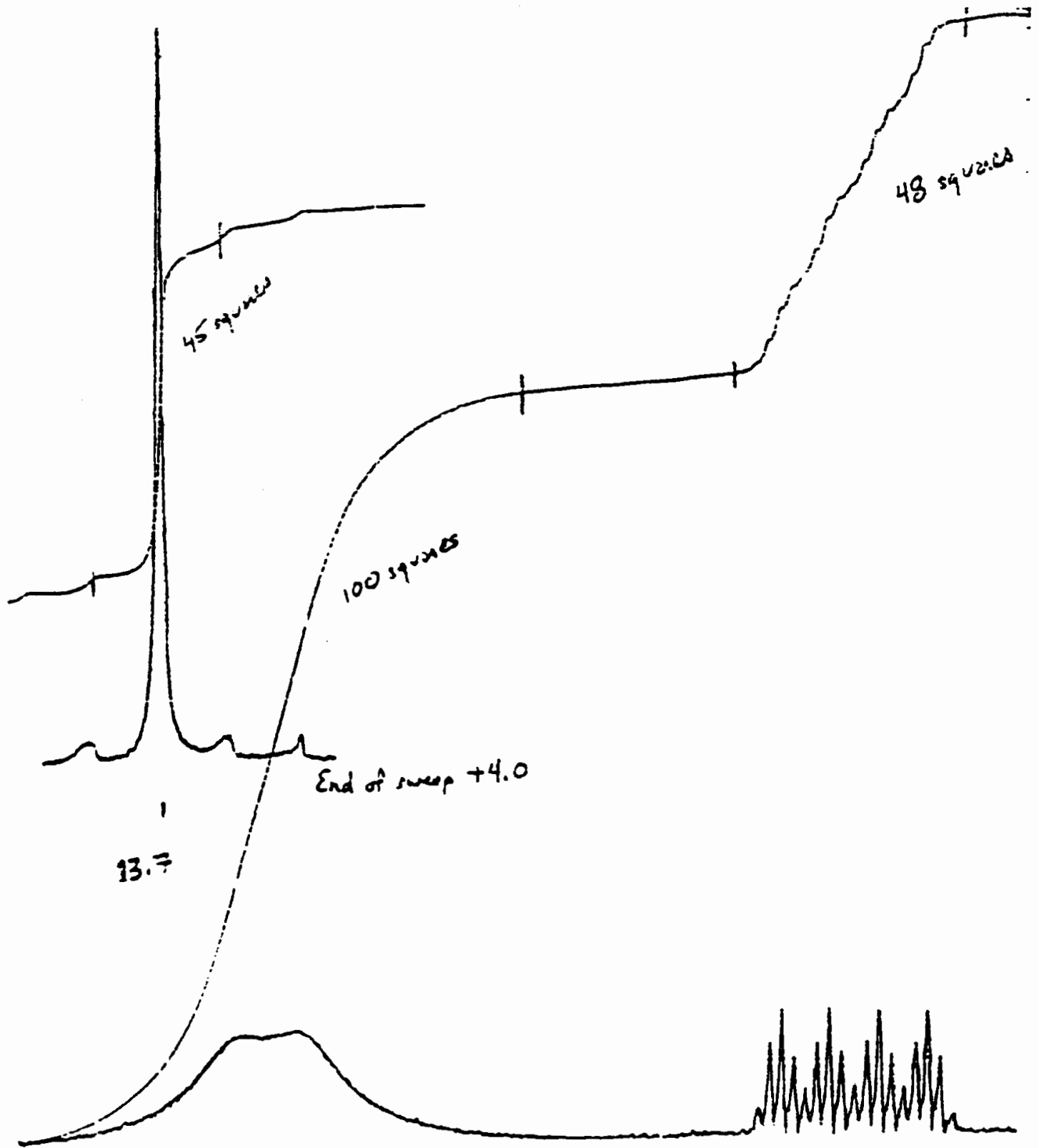

IH NMR spectrum of $\bar{F}_{5} \mathrm{CHFCF}_{2} \mathrm{SO}_{3} \mathrm{H} \cdot \mathrm{H}_{2} \mathrm{O}$ 


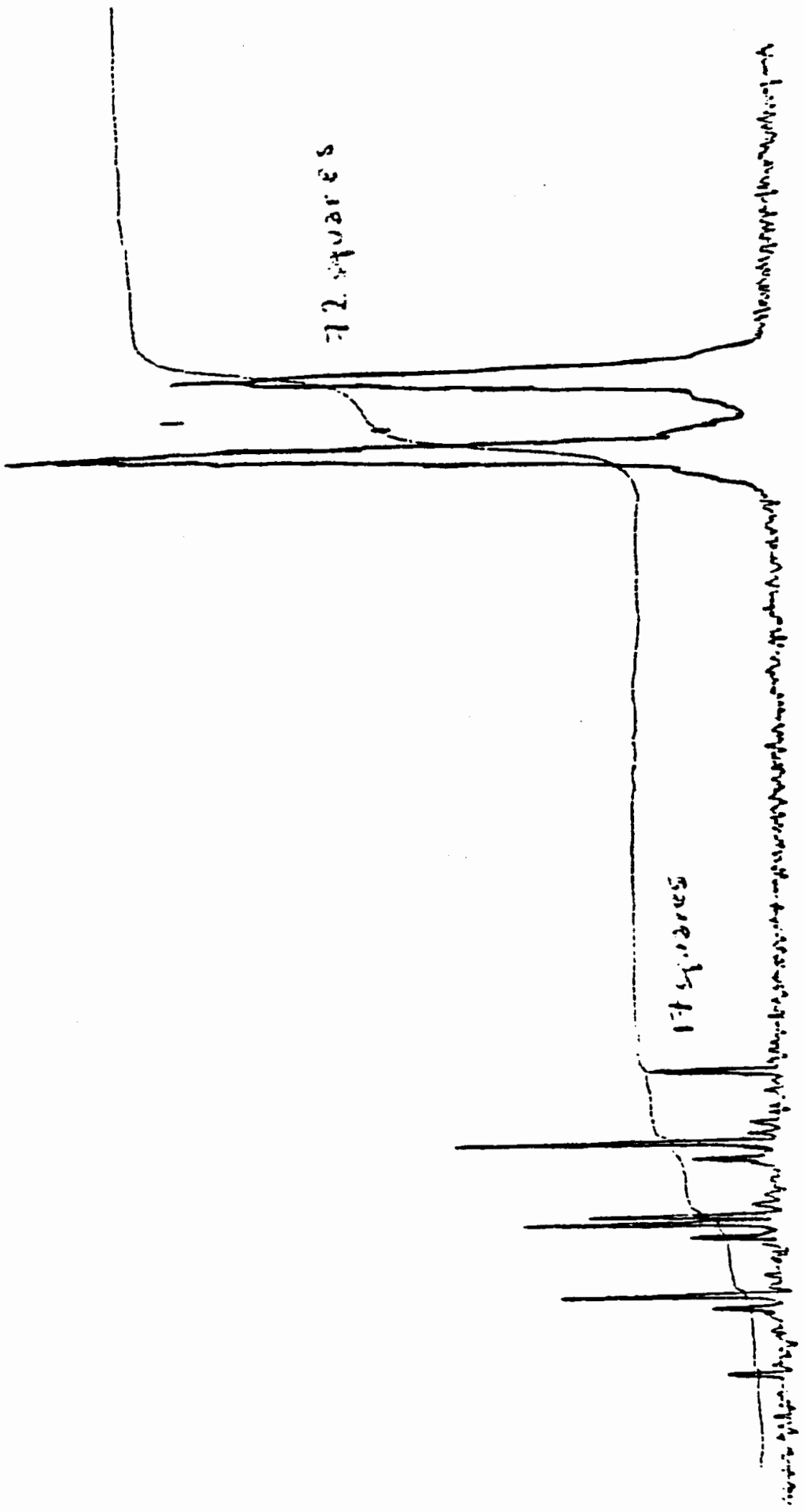

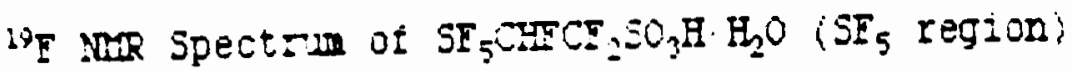




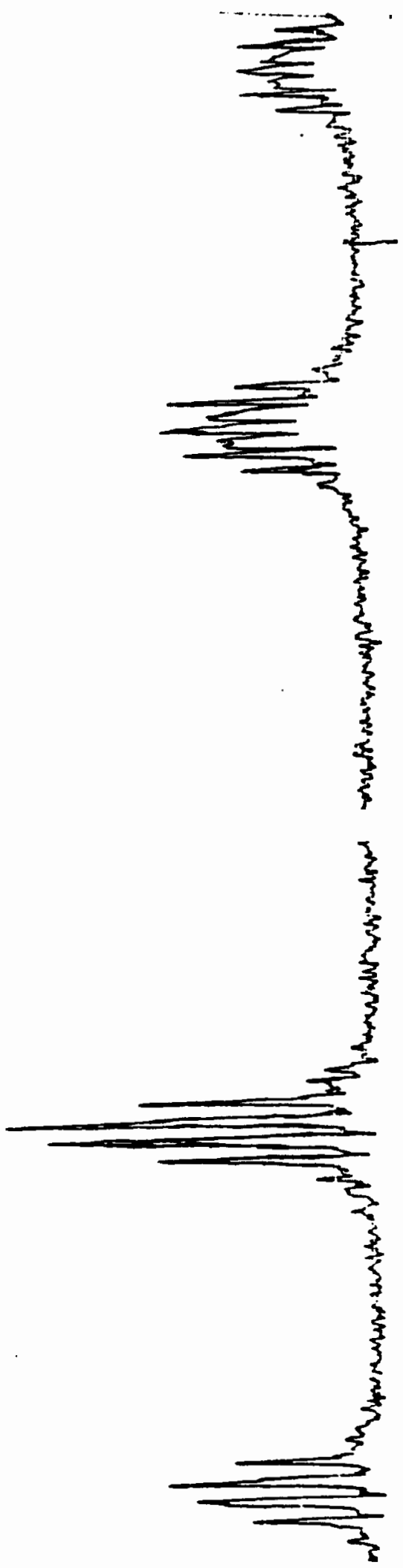

${ }^{19} \mathrm{~F}$ NIR Spectrum of $\mathrm{SF}_{5} \mathrm{CHFCF}_{2} 3 \mathrm{O}_{3} \mathrm{H} \cdot \mathrm{B}_{2} \mathrm{O}$ (CE , region) 


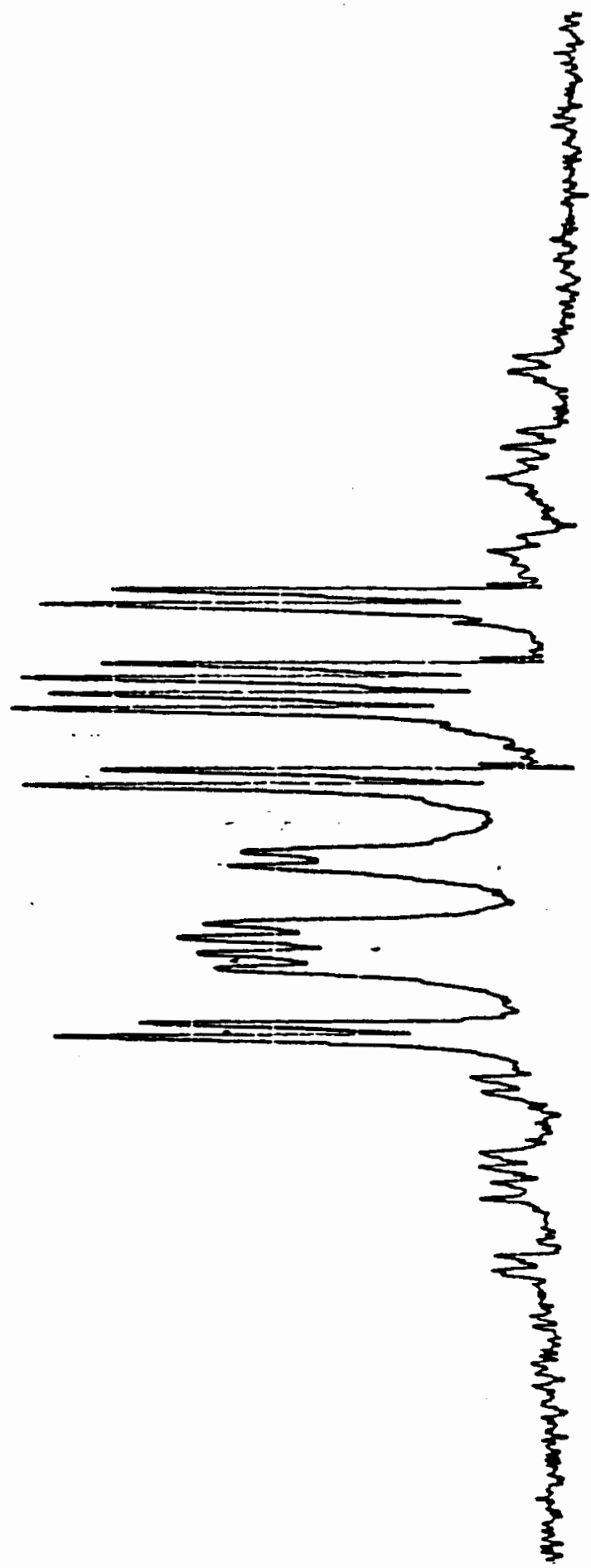

${ }^{19}$ NIR Spectrum of $\mathrm{SF}_{5} \mathrm{CHFCF}_{2} \mathrm{SO}_{3} \mathrm{H} \cdot \mathrm{H}_{2} \mathrm{O}$ (CF region) 


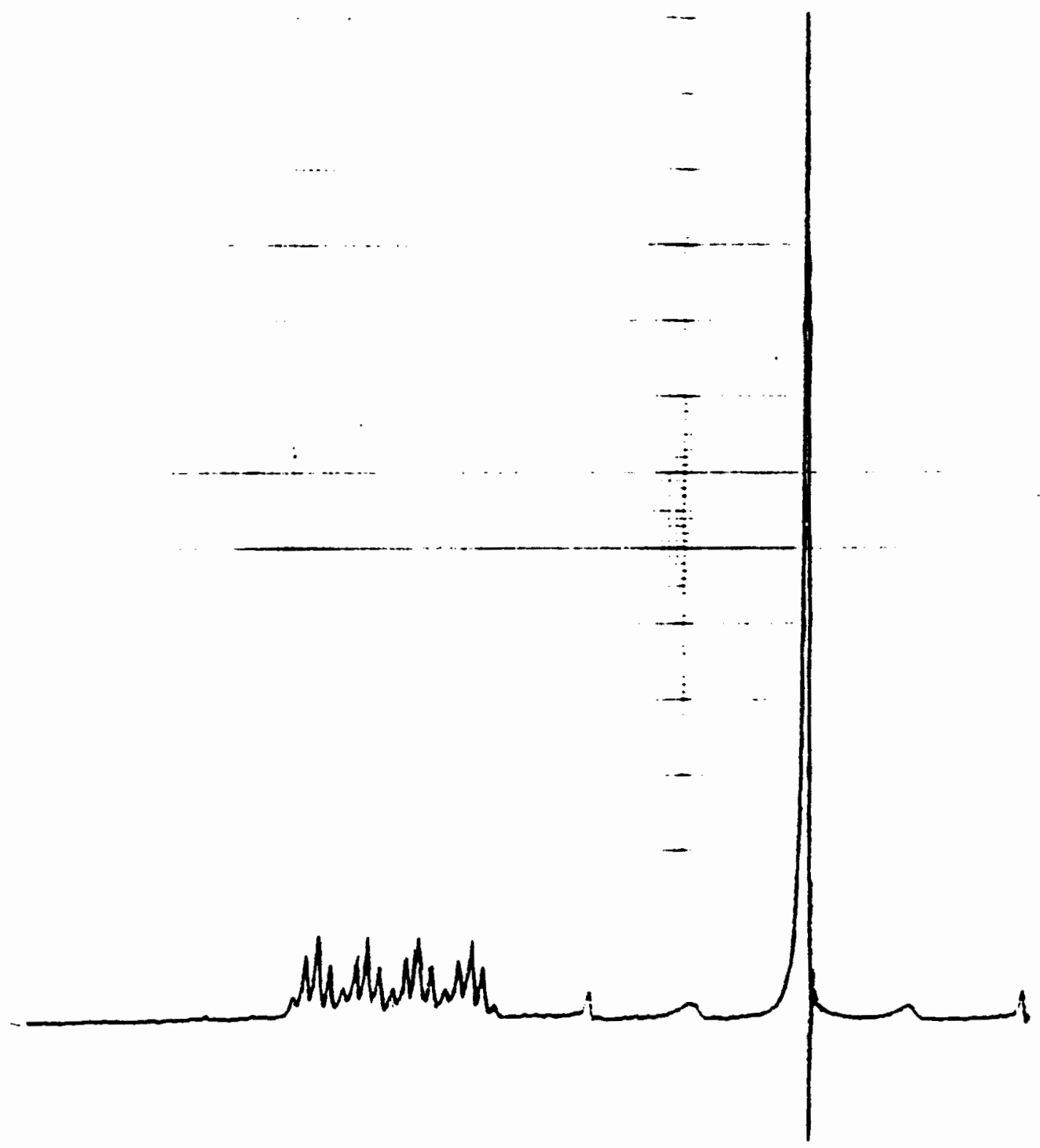

ig un spectrum of $\mathrm{SF}_{5} \mathrm{CHFCF} 25 \mathrm{O}_{3} \mathrm{Na}$ 


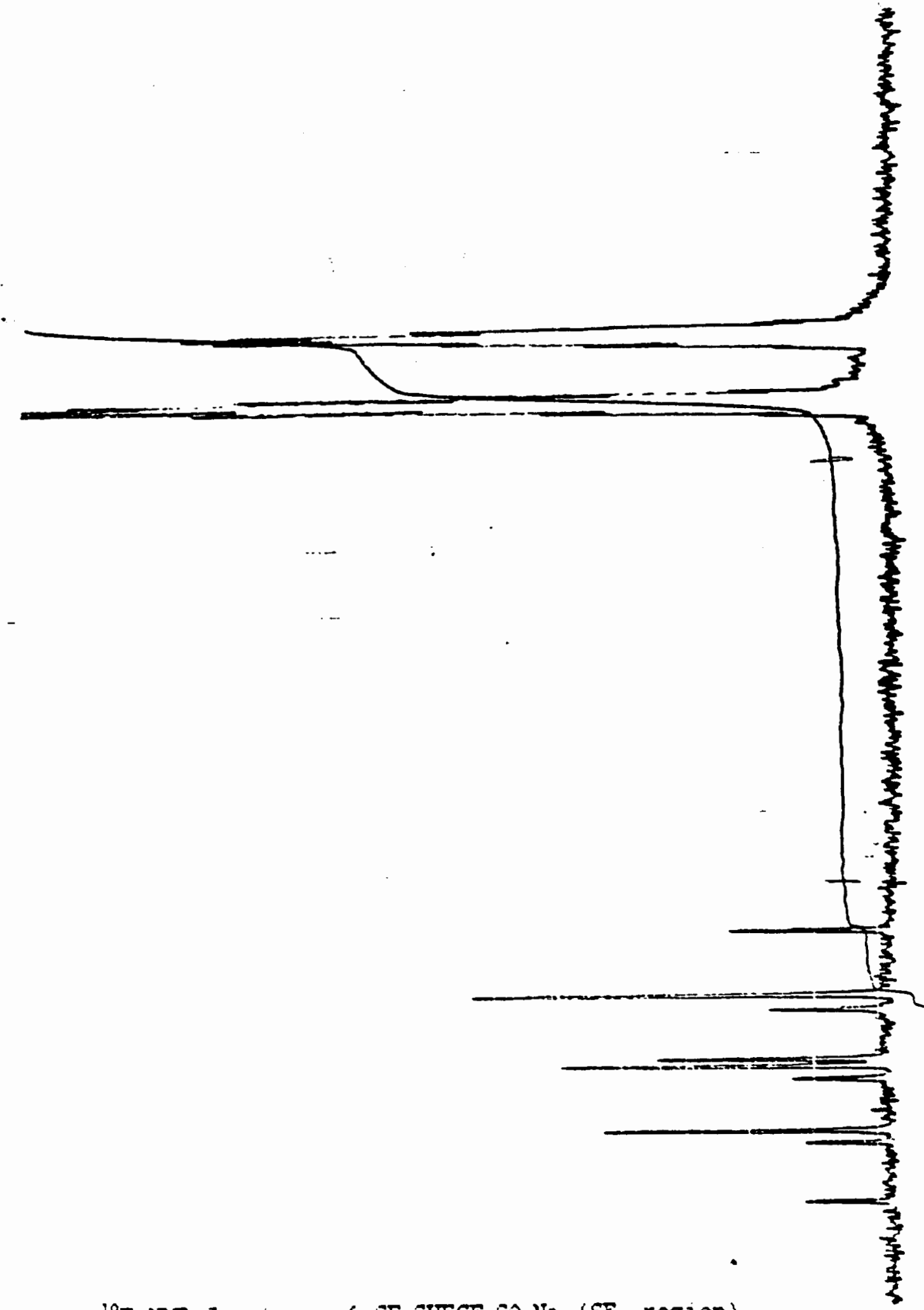

19F NaF Spectrum of $\mathrm{SF}_{5} \mathrm{CHFCF}_{2} \mathrm{SO}_{3} \mathrm{Ha}$ (SF region) 


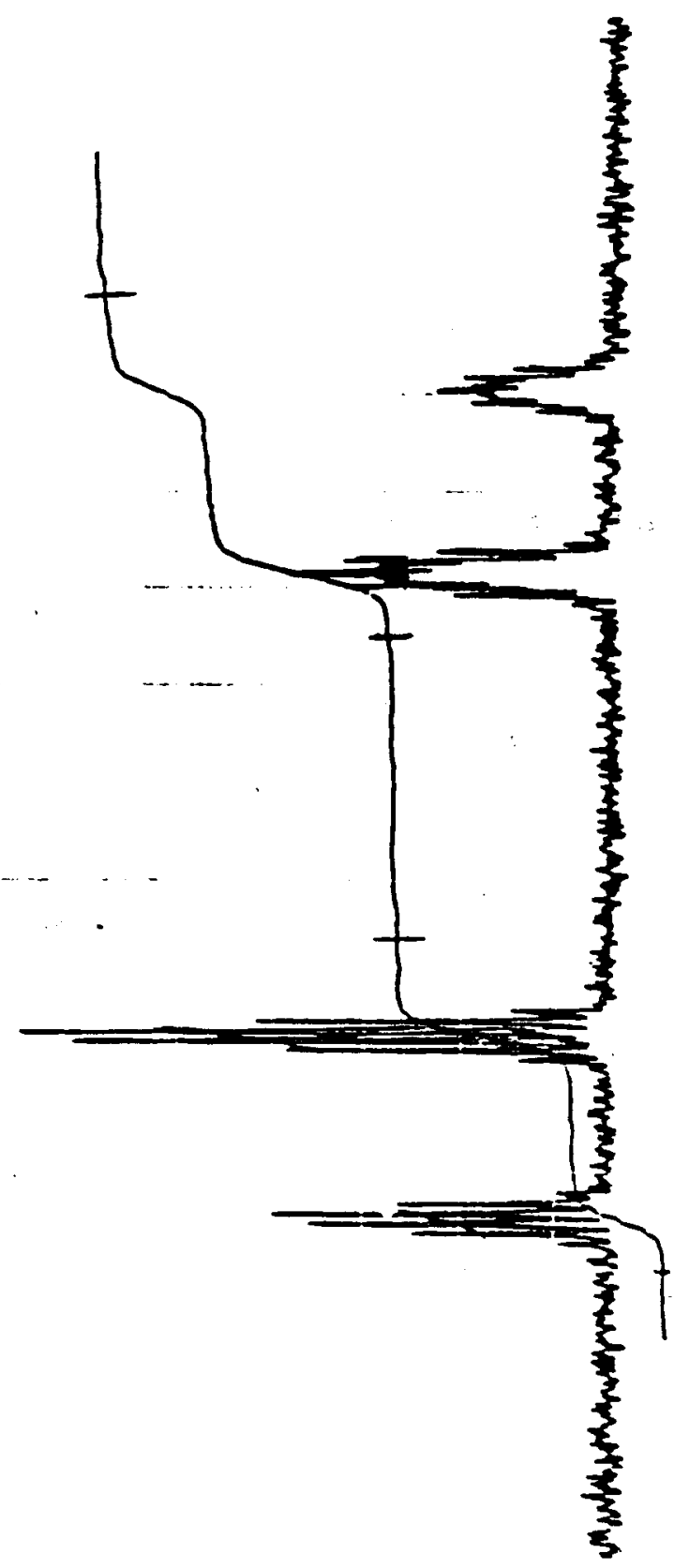

19T NRF Spestrum of $\mathrm{SF}_{5} \mathrm{CHFCF} \mathrm{SO}_{3} \mathrm{Na} \quad\left(\mathrm{CF}_{2}\right.$ region) 


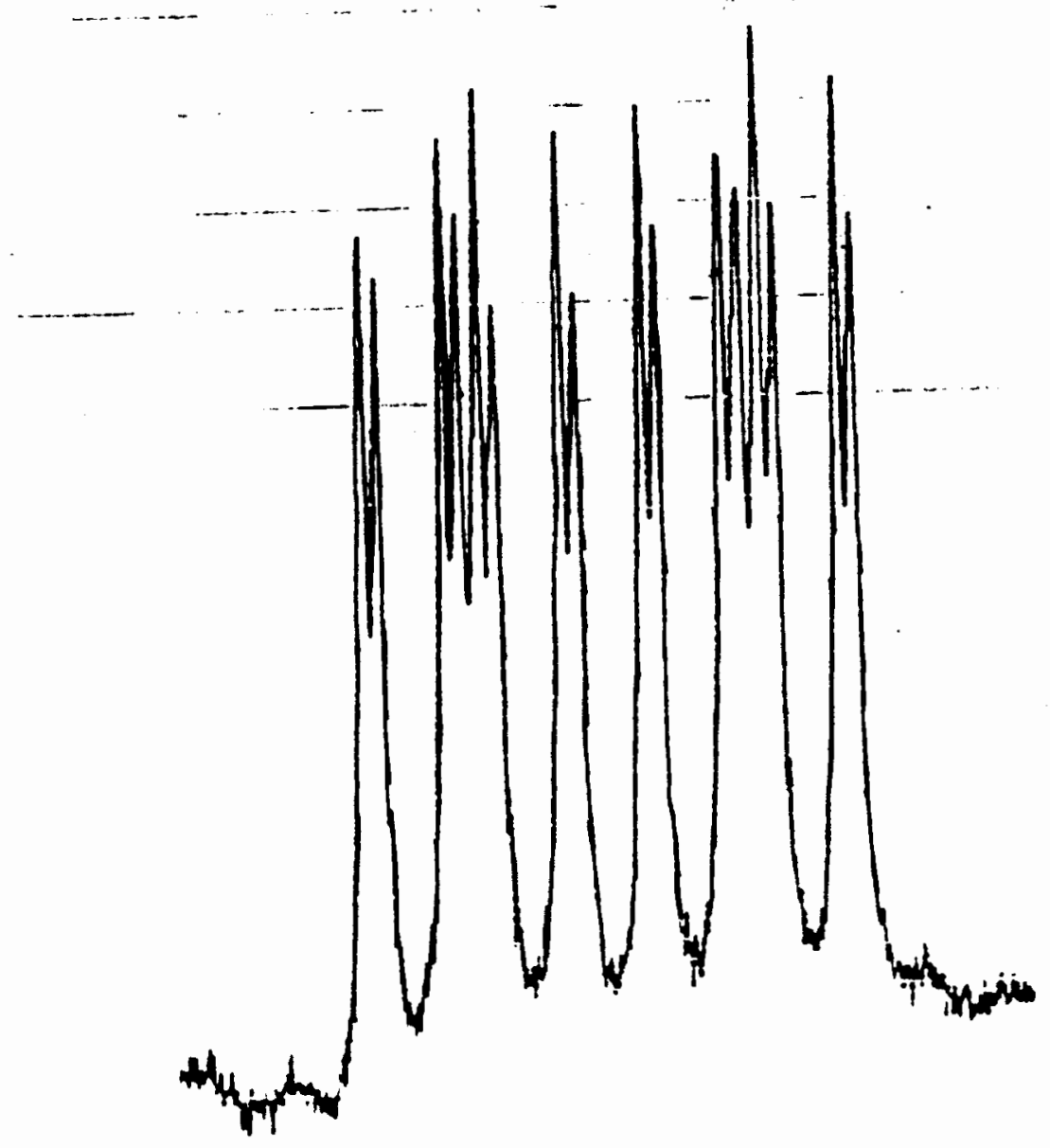

19F UNF Spectrum of $\mathrm{SF}_{5} \mathrm{CHF} \mathrm{T}_{2} \mathrm{SO}_{3} \mathrm{Na}$ (CF region) 

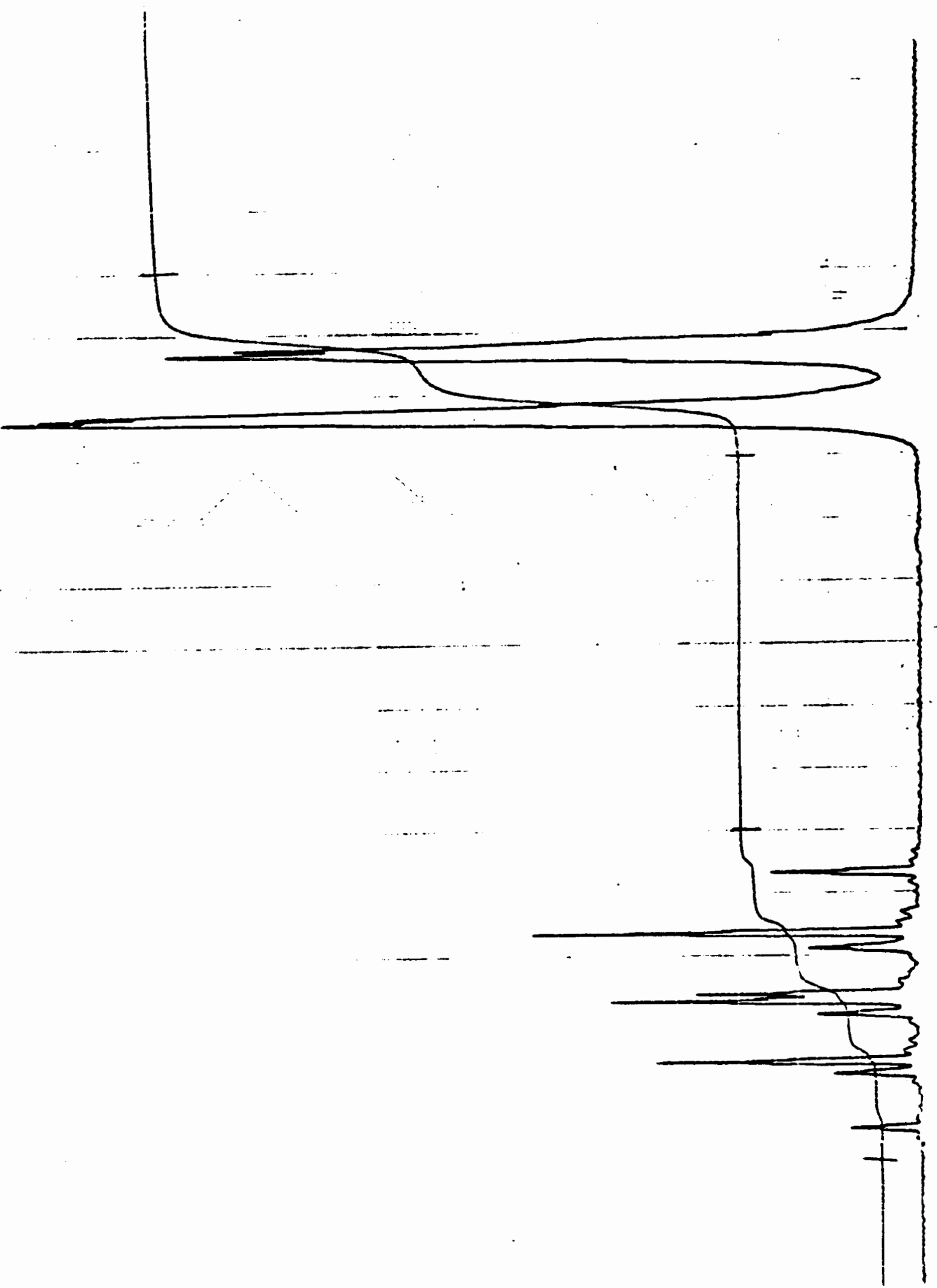

${ }^{19} \mathrm{~F}$ NMR Ejection of $\mathrm{SF}_{5} \mathrm{CF}_{2} \mathrm{CFBr}_{2}$ (SF 5 region) 


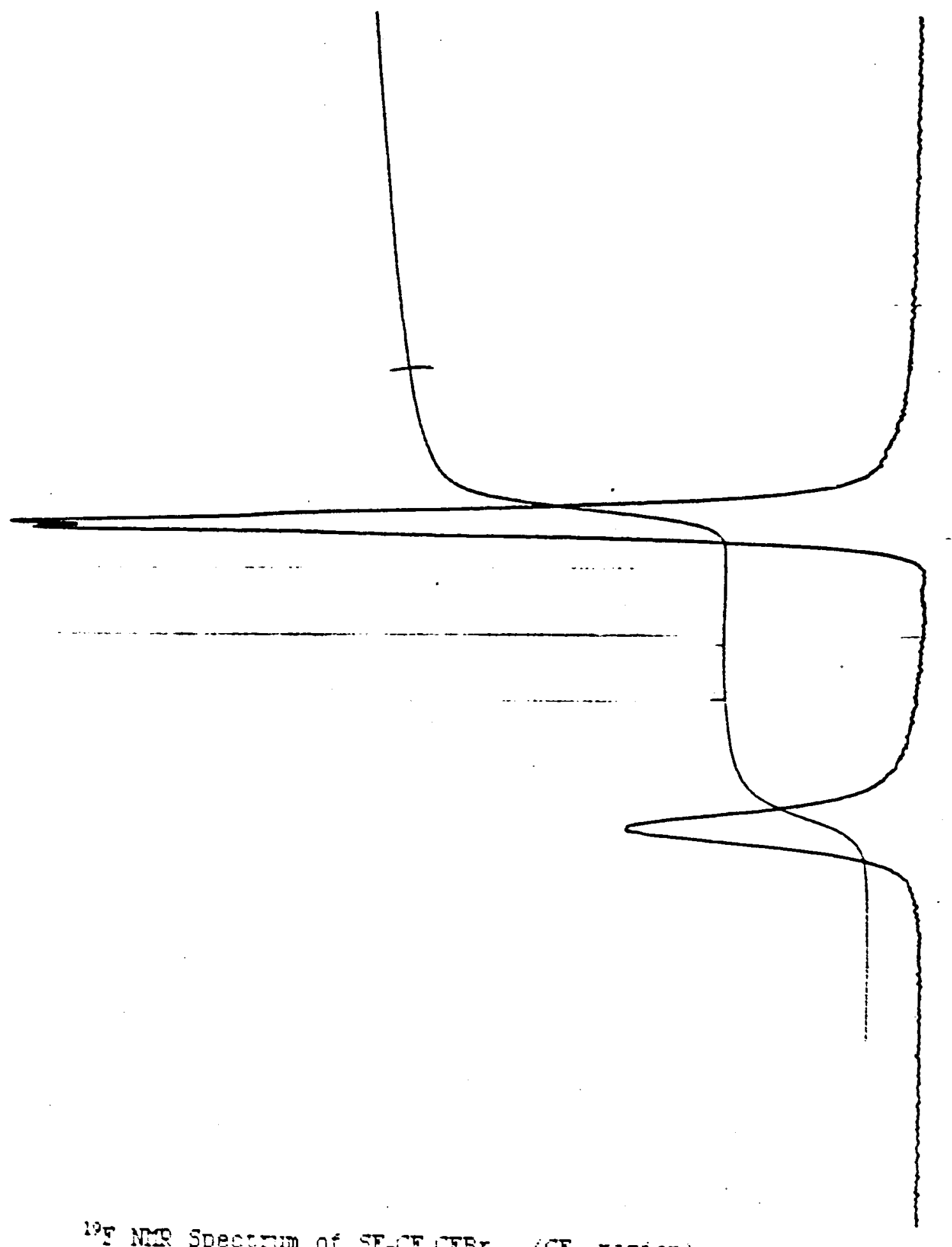

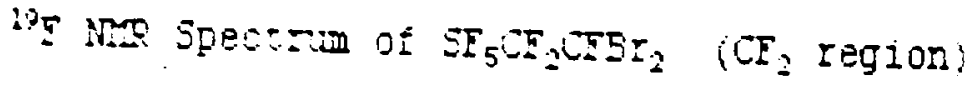




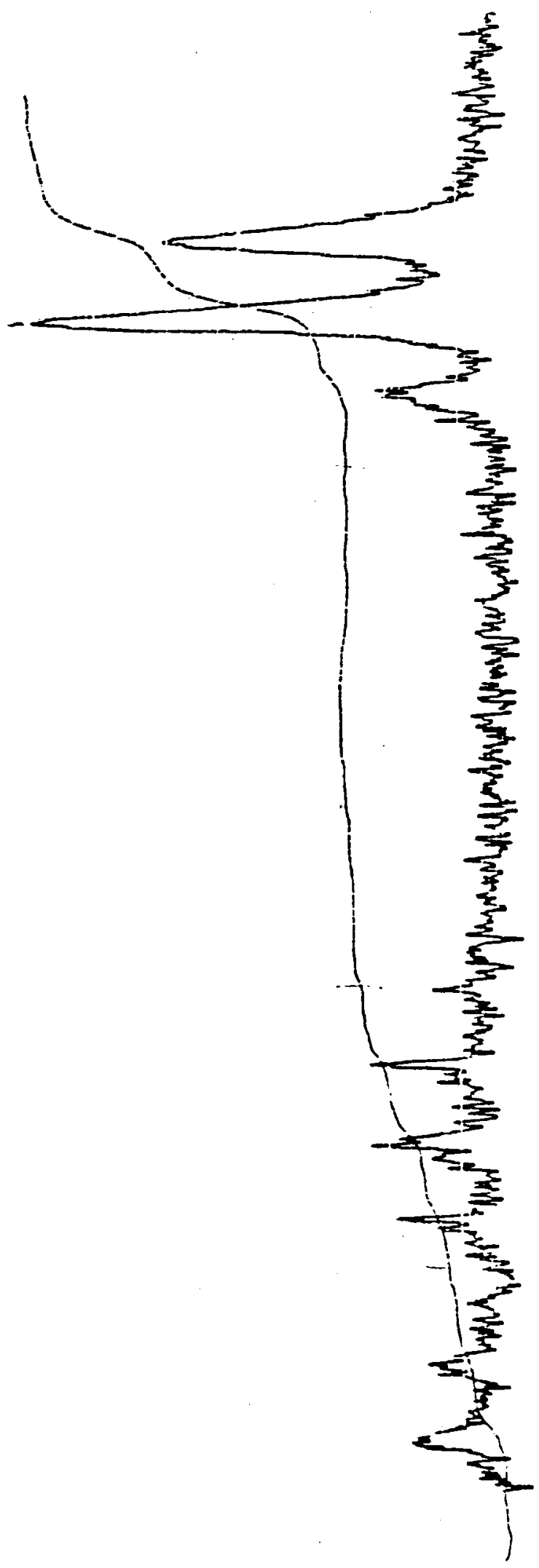

:P NRR Esectrum of $S F_{5}\left(C F_{2} C F B r\right)_{10} B r\left(S F_{5}\right.$ zegion) 


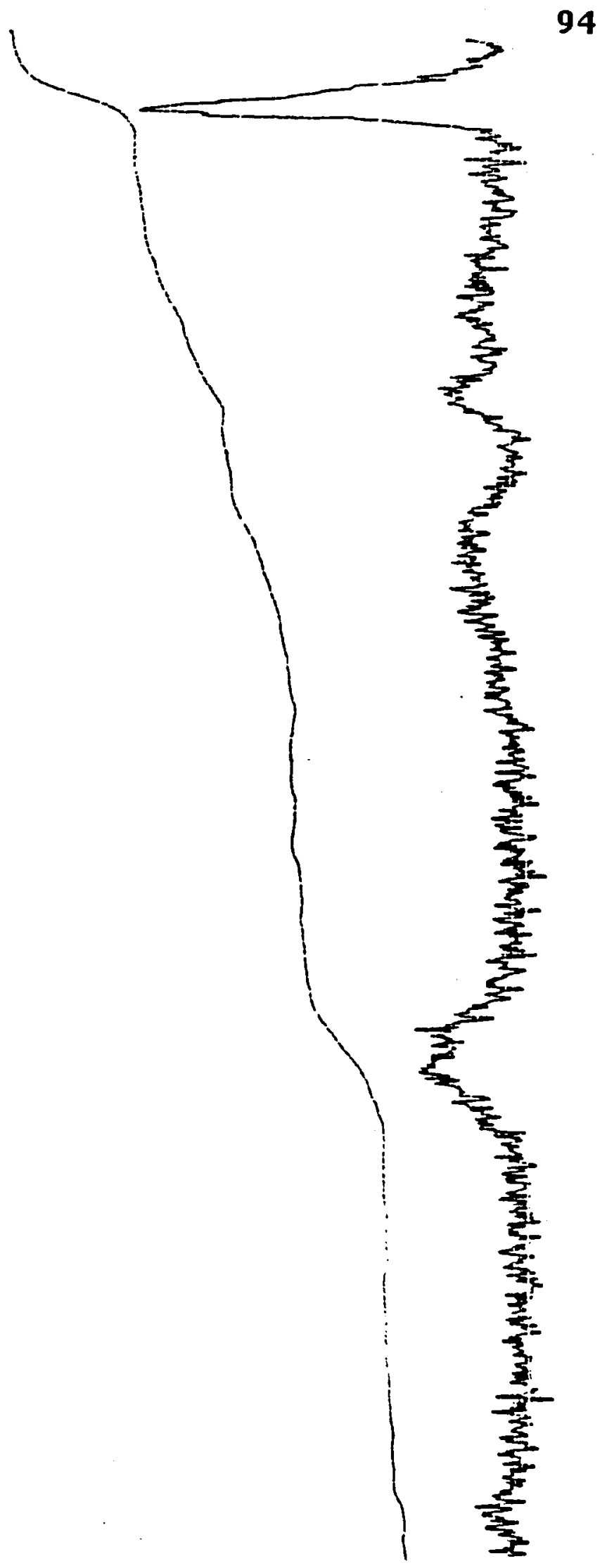

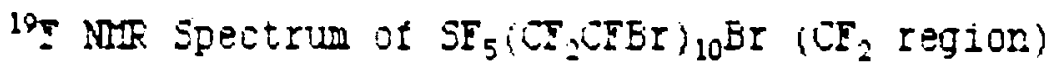




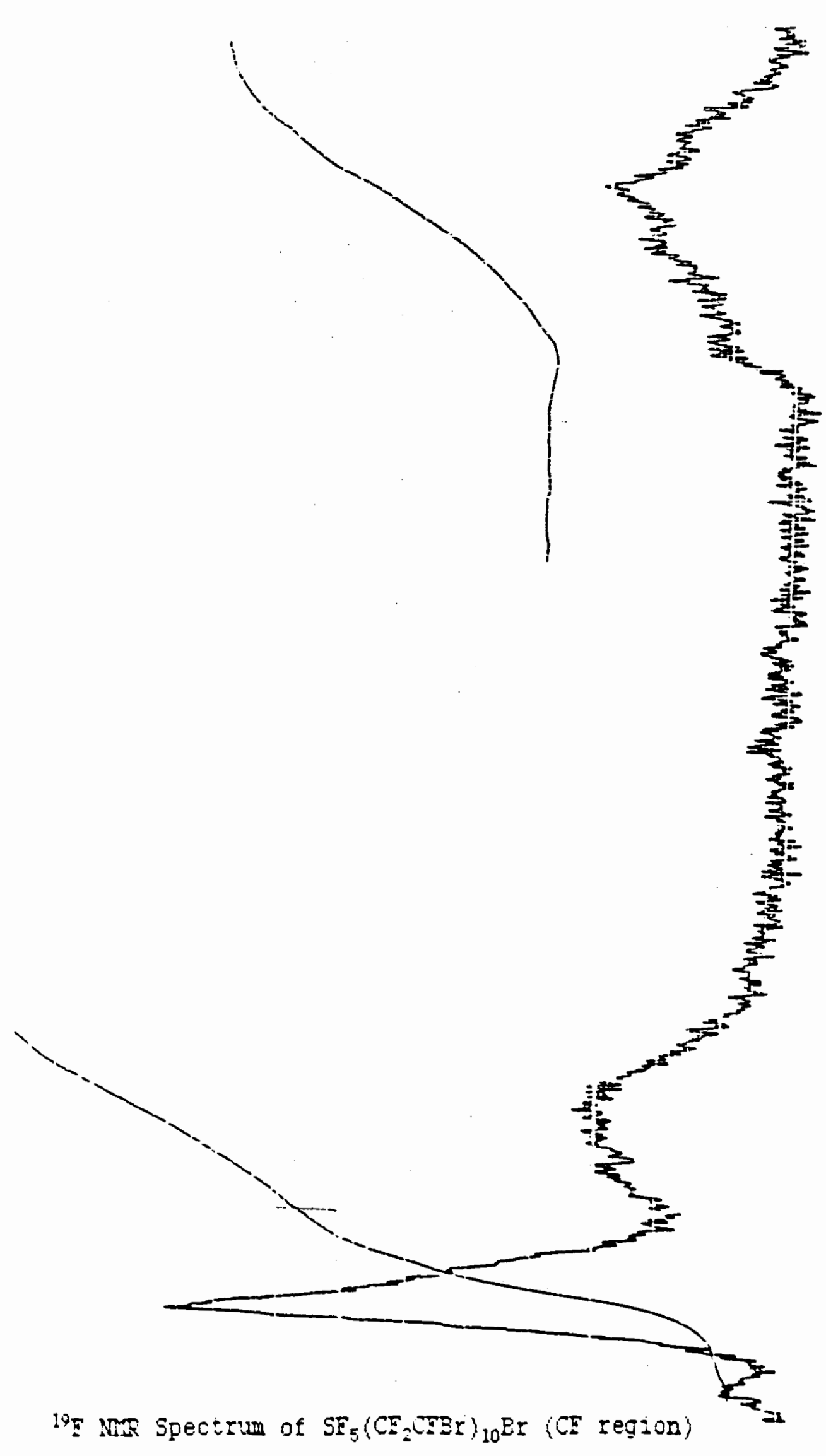

